\title{
REGISTERED DIETITIAN'S PERSONAL BELIEFS AND CHARACTERISTICS PREDICT THEIR TEACHING OR INTENTION TO TEACH FRESH VEGETABLE FOOD SAFETY
}

\author{
Masters Thesis \\ Presented in Partial Fulfillment of the Requirements for the Degree Master of Science \\ in the Graduate School of The Ohio State University \\ By \\ Gina Michelle Casagrande, B.S \\ College of Education and Human Ecology \\ The Ohio State University \\ 2009
}

Thesis Committee:

Professor Lydia Medeiros, Advisor Professor Martha Belury Associate Professor Jeffrey LeJeune 
Copyright By

Gina Casagrande

2009 


\section{ABSTRACT}

In the United States, the most popular fresh produce is fresh-cut salads, with sales of $\$ 2.7$ billion per year. Consumers may not be knowledgeable about fresh vegetable food safety and an increasing number of foodborne disease outbreaks are linked to fresh vegetable consumption. Registered dietitians (RDs) are considered the spokespeople for food and nutrition and therefore have a professional responsibility by standards of practice to incorporate food safety into their client/patient education. But, are they including this information in their client/patient education? This study used the Theory of Planned Behavior (TPB) to determine RD's personal characteristics and beliefs about teaching fresh vegetable food safety that predict whether they currently teach, intend to teach, or neither currently teach nor intend to teach fresh vegetable food safety to their clients/patients. A survey was created for web implementation to determine three types of salient beliefs: normative (n), behavioral (b), and control (c). These were evaluated as three independent belief variables: Perceived Behavioral Control (PBC), Attitudes (Atd), and Subjective Norm (SN). Variables were evaluated using five-point Likert scales. Three hundred and 
twenty seven RDs who participate in direct client/patient education responded to this survey. Spearman correlation analysis was completed to determine the variables that correlated best with current teaching behavior. Multinomial logistical regression was conducted to determine if the TPB belief variables significantly predicted RD's teaching behavior. Binary logistic regression was used to determine which variable was the better predictor of whether the RD currently taught. After controlling for age, income, political philosophy, education, and gender, the multinomial logistical regression was significant $\left(\mathrm{R}^{2}=0.35, \mathrm{p} \leq 0.001\right)$. Therefore the TPB significantly predicted RD's current fresh vegetable food safety teaching behaviors. PBC was the better predictor of whether an RD currently taught fresh vegetable food safety $\left(\mathrm{R}^{2}=0.19, \mathrm{P} \leq 0.001\right)$. Having confidence in fresh vegetable food safety knowledge, being socially influenced to teach, and having positive attitudes towards the behavior significantly affected whether an RD currently taught. These results may be used to create more effective food safety curriculum for RDs. 


\section{ACKNOWLEDGMENTS}

I would like to thank my advisor, Dr. Lydia Medeiros, for coming to my rescue when my first research project fell through. I especially appreciate her willingness to put up with my "moods" and her help and support as I struggled through the most difficult part of my research, the statistics!

I want to thank Janet Buffer for all her assistance and her positive attitude throughout my IRB process. I also thank Janet for lending me her unconditional support and advice, as well as her cell-phone number, all of which provided tremendous help during my research process.

I would like to thank Dr. Martha Belury and Dr. Jeffrey LeJeune for serving on my committee. I also thank Yoonsuh Jung for helping me with my statistics, and Eric Lauterbach for all of his help in converting my survey to online format.

If not for these people I would not have been successful in completing my thesis and there are no words that can describe my immense appreciation for their time, and willingness to help me throughout the last year. 
VITA

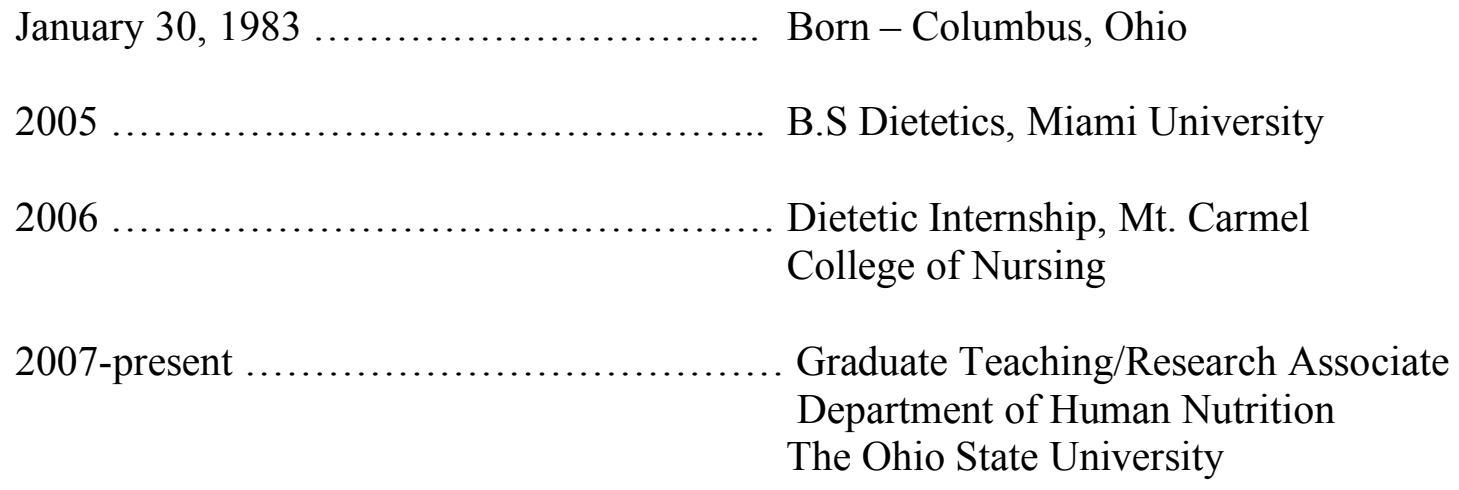

FIELDS OF STUDY

Major Field: Human Ecology

Area of Emphasis: Human Nutrition 


\section{TABLE OF CONTENTS}

\section{Page}

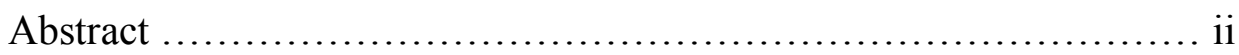

Acknowledgment .......................................... iii

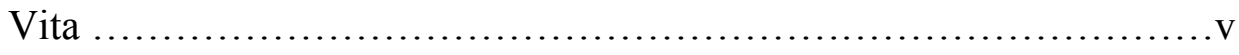

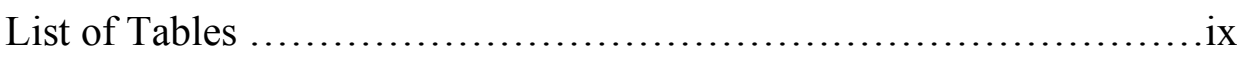

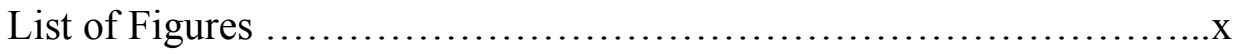

List of Abbreviations ...........................................

Chapters:

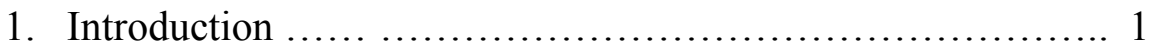

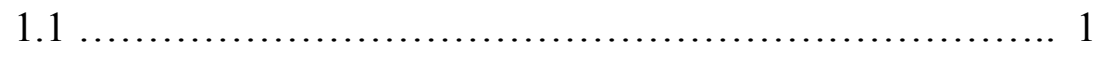

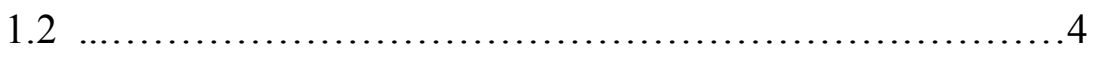

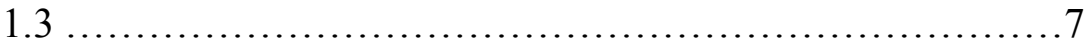

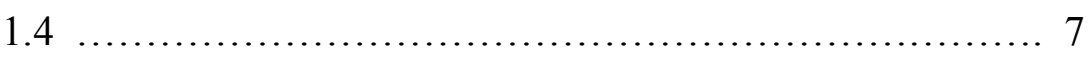

2. Review of Literature ................................. 9

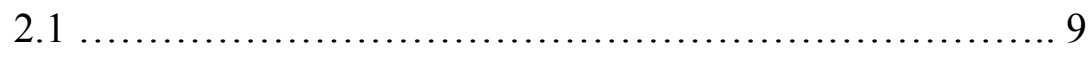

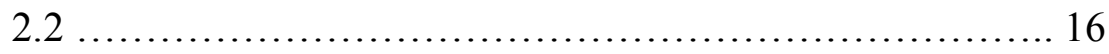


3. Registered Dietitian's Personal Beliefs and Characteristics That Predict Their Teaching Or Intentions to Teach Fresh Vegetable

Food Safety ......................................... 39

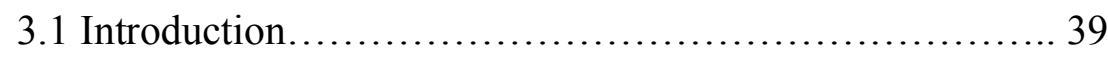

3.2 Materials and Methods............................. 42

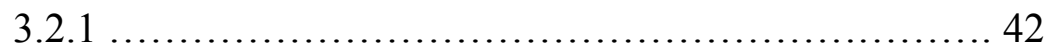

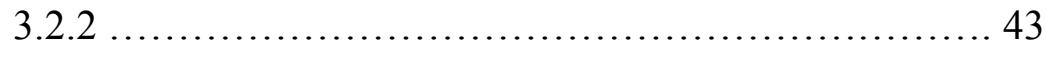

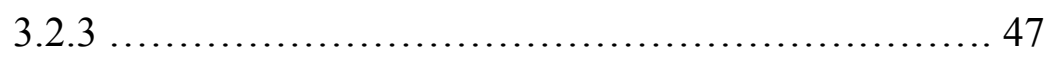

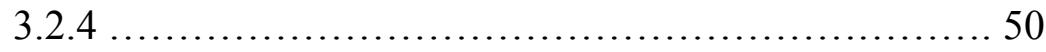

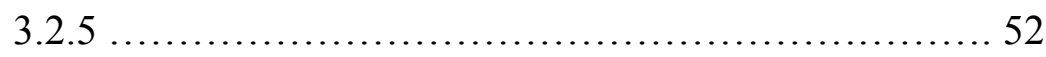

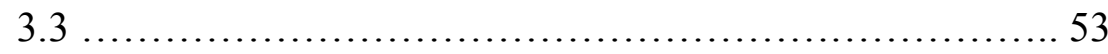

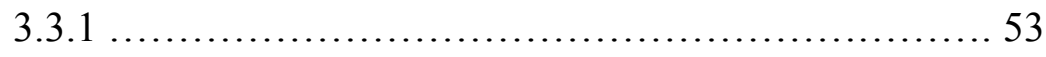

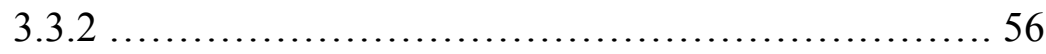

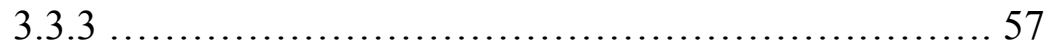

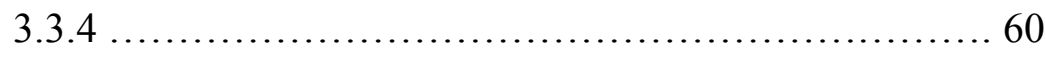




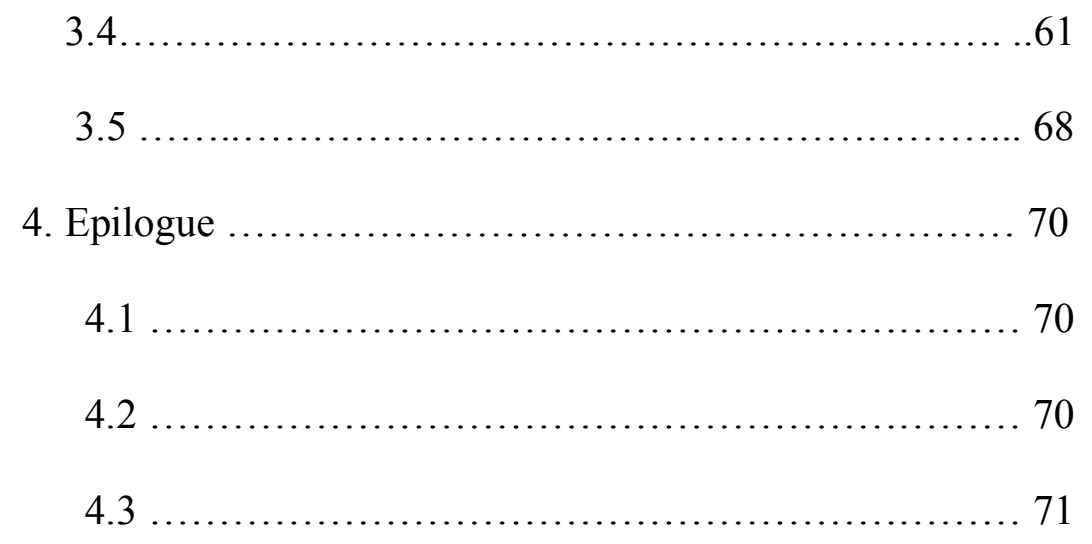

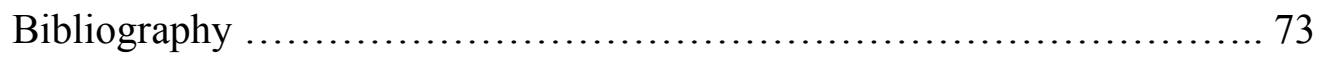

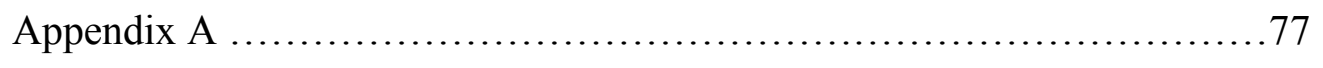

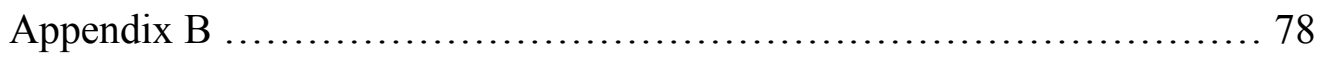

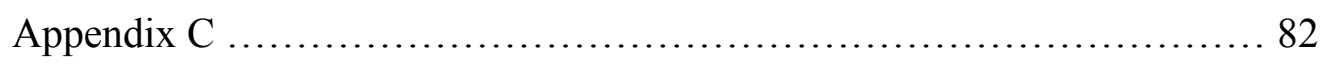

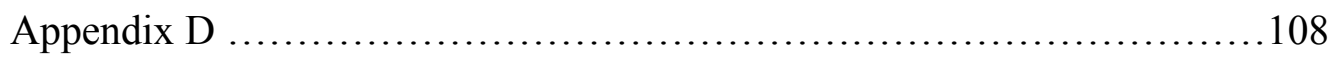




\section{LIST OF TABLES}

Table

Page

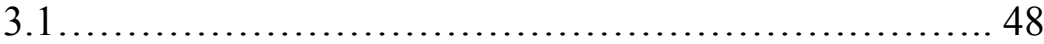

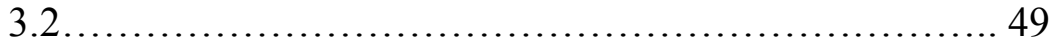

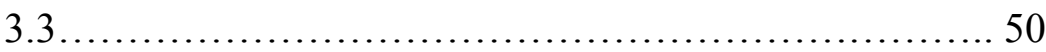

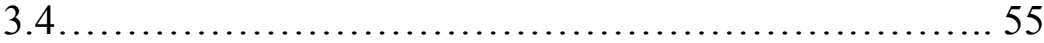

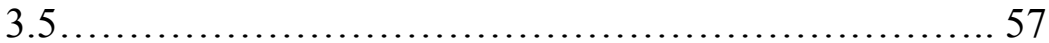

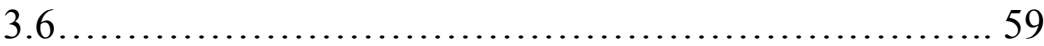

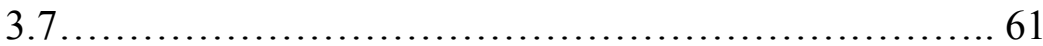




\section{LIST OF FIGURES}

Figure

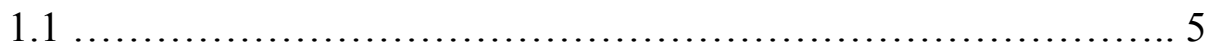

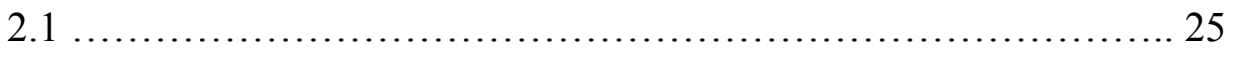

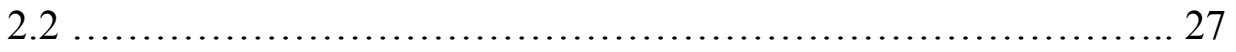

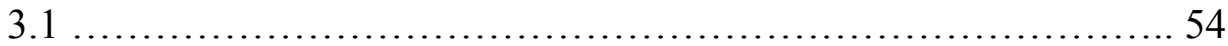




\section{LIST OF ABBREVIATIONS}

TRA $=$ Theory of Reasoned Action

$\mathrm{TPB}=$ Theory of Planned Behavior

$\mathrm{PBC}=$ Perceived Behavioral Control

Atd $=$ Attitude

$\mathrm{SN}=$ Subjective Norm

$\mathrm{c}=$ "control beliefs"

b = "behavioral beliefs"

$\mathrm{n}=$ "normative beliefs"

Full attitude belief variable $=$ The attitude belief variable that included each of the 20 belief/evaluation pairs.

Full model $=$ The Theory of Planned Behavior model, which included the full attitude belief variable.

"Best-fit predictive model" = The Theory of Planned Behavior, which included only the seven belief/evaluation pairs significantly correlated with the multinomial dependent variable. 


\section{CHAPTER 1}

\section{INTRODUCTION}

\subsection{Overview}

Fresh produce are those that are raw and in their natural state. Fresh-cut produce is slightly different in that peeling, slicing, chopping, shredding, coring, or trimming minimally processes it. Fresh-cut produce may or may not be washed or treated in other ways prior to packaging for retail sale (1). For this study, fresh produce will be used to refer to both fresh and fresh-cut produce.

Most people associate foodborne illnesses with contaminated meat, poultry or dairy products, but the Center for Disease Control (CDC) reports a continuing emergence of pathogens and an increased proportion of bacterial outbreaks caused by contaminated vegetables (2). From 1996 to 2006, seventy-two foodborne illness outbreaks were linked to the consumption of contaminated fresh produce (1). The organisms that are responsible for a majority of foodborne illnesses can be found 
throughout nature, in plants, people, animals and the soil in which fresh produce is grown (2). Since 1995, the FDA reports 22 foodborne illness outbreaks in the United States have been caused by E.coli $\mathrm{O} 157: \mathrm{H} 7$ that were association with consumption of either fresh-cut or pre-washed spinach (3). In 2006, over 200 people were affected by a nationwide outbreak of E.coli $\mathrm{O} 157: \mathrm{H} 7$, the cause of which was eventually identified as pre-washed spinach. Similar outbreaks in 2003 were associated with bagged pre-washed spinach and romaine-iceberg mix. In 2008, tomatoes were attributed to a nationwide Salmonella outbreak, but the causative agent was later found to be associated with contaminated jalapeno peppers (3). These high-profile outbreaks have had a tremendous effect on food safety regulation by changing some of the food safety emphasis to pasteurization of juices and cleaning fresh fruits and vegetables, rather than just testing meats and other protein foods (4).

Fresh produce and fresh-cut produce are consumed by more and more Americans each year, a likely result of the recommendations made by the Federal Government's Dietary Guidelines for Americans and the related MyPyramid food guidance system $(5,6)$. The dietary guidelines specifically recommend 2 cups of fruit and $2 \frac{1}{2}$ cups of vegetables per day for someone consuming a 2000-calorie diet (1). Recommendations are higher for those who consume more than 2000 calories. Freshcut fruit and vegetable sales are at $\$ 15$ billion in the North American foodservice and retail market, which accounts for about 15 percent of total produce sales (3). Among the most popular fresh produce is fresh-cut salads, with a sales of $\$ 2.7$ billion per year (3). This study focuses on fresh vegetables, specifically leafy greens and tomatoes. Registered dietitians often stress the consumption of fresh vegetables to their 
clients/patients for their nutritional quality and research-based health benefits. Unexpectedly, however, increased sales of fresh vegetables have coincided with increases in reported foodborne illness outbreaks associated with their consumption, specifically among fresh-cut leafy greens (3). Because RDs are the one's who often give the advice to consume fresh vegetables, they should also know about fresh vegetable food safety (4). Registered dietitians are considered food and nutrition experts and have met specific experiential and educational criteria, including the completion of a bachelor's degree at an accredited university (7). The didactic undergraduate programs and dietetic internships that are available throughout the United States have specific content focus, such as food management or medical nutrition, and they may or may not have additional food safety- related requirements beyond the core requirements that are needed for graduation and eventual dietetic registration. Prospective RDs are also required to complete an internship after they earn their bachelor's degree, for which there are required competencies created by the Commission on Accreditation for Dietetics Education (CADE) (7). In relation to food safety, RDs are required to have the ability to "apply safety principles related to food, personnel and consumers" and "develop and deliver products, programs or services that promote consumer health, wellness and lifestyle management merging consumer desire for taste, convenience and economy with nutrition, food safety and health messages interventions" (7). These competencies are required regardless of the employment field of dietetics one plans to enter. Yet, some questions are unanswered. Is the food safety education, specifically the fresh vegetable food safety 
education, effective at teaching prospective RDs the necessary information? Once prepared for practice how do RDs perform as food safety educators?

Researchers in risk perception research have concluded that risk communication works best when taught from a "bottom-up" approach, rather than a "top-down" approach (8). This "bottom-up" form of teaching focuses more on the types of information individuals actually need, rather than what experts in the particular field think they should have (8). Instead of assuming that risk information does something to an individual, it is more important to illuminate the process that may ultimately cause people to adapt certain behaviors (8). This concept can be incorporated into the fresh vegetable food safety education materials for dietitians.

\subsection{Study Design}

The current study used a descriptional, cross-sectional survey design. The survey was composed of questions that were derived from a review of the literature on Icek Aizen's Theory of Planned Behavior $(9,10,11)$ with specific focus on the studies done by Griffin et al. $(12,13)$. This group used the Theory of Planned Behavior to evaluate beliefs about drinking parasite-contaminated tap water. Using this theoretical model the current study was designed to determine RD's personal characteristics and beliefs about teaching fresh vegetable food safety that predict whether they currently teach, intend to teach, or neither currently teach nor intend to teach fresh vegetable food safety to their clients/patients. The belief variables were created from the salient beliefs of RDs regarding teaching clients/patients about fresh vegetable food safety. Salient beliefs were used to create the three independent belief 
variables: Perceived Behavioral Control (PBC), Attitudes (Atd), and Subjective Norm

(SN). Figure 1.1 shows the adapted model of the Theory of Planned Behavior.

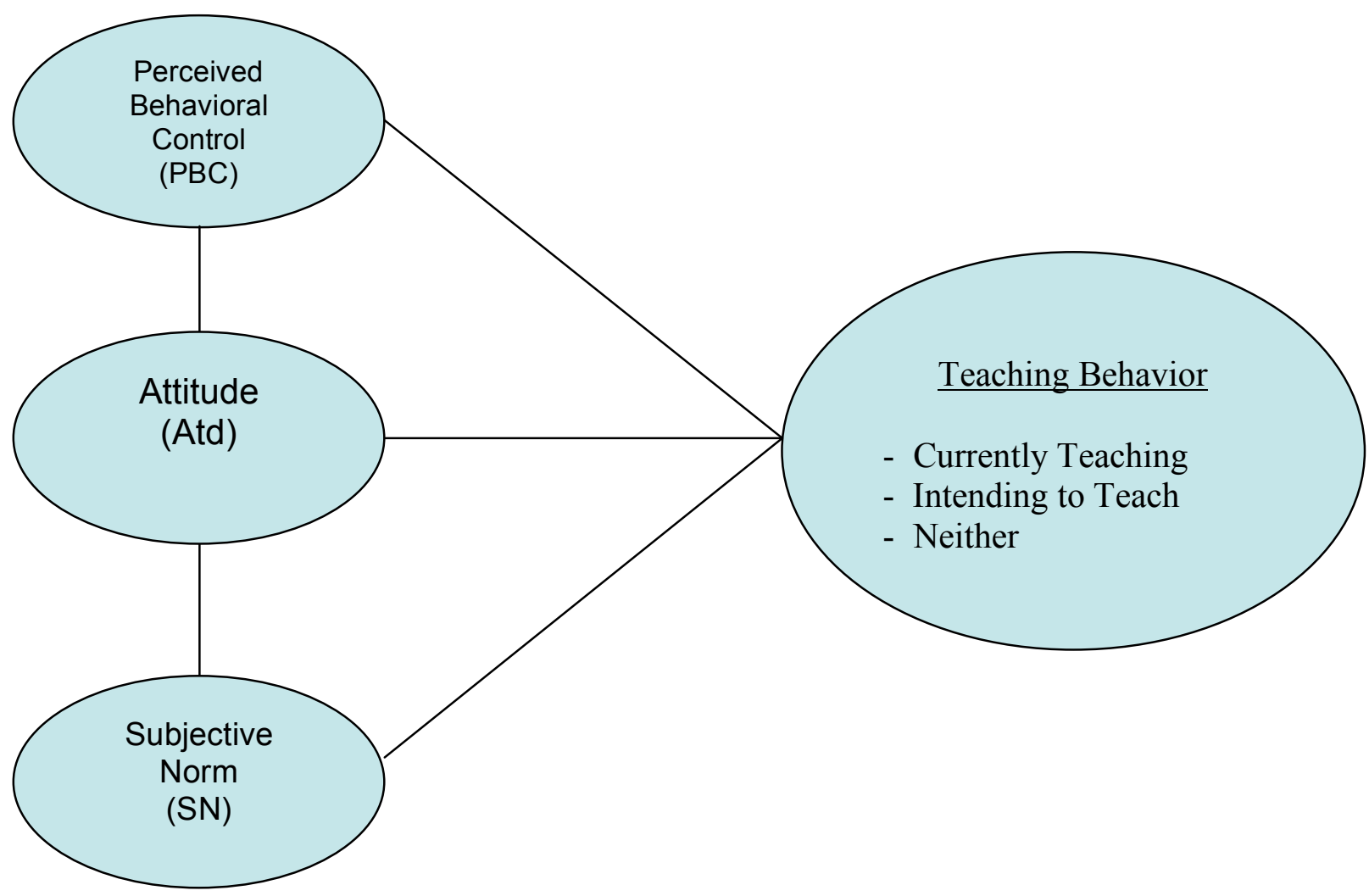

Figure 1.1. The Adapted Model of The Theory of Planned Behavior. This model represents the independent belief variables: Perceived Behavioral Control, Attitudes, and Subjective Norm, and their influence on Teaching Behavior. Perceived behavioral control, attitude, and subjective norm are conceptually independent predictors of behavioral outcome. The lines connecting the variables denote that they are usually found to be empirically correlated because the same information can influence control, behavioral, and/or normative beliefs, their theoretical antecedents, respectively. Adapted from Aizen, 1988.

Perceived behavioral control (PBC) refers to the anticipated ease or difficulty of performing a behavior, which is determined by "control beliefs" (c) $(9,10,11)$. 
Attitudes (Atd) refer to the person's beliefs about the outcomes of the behavior ("behavioral beliefs" (b)) and their positive or negative evaluations of those particular beliefs ("outcome evaluations" (e)). Subjective Norm (SN) refers to whether an individual thinks that others important to them believe the behavior is something that he or she should perform ("normative beliefs" (n)), and it accounts for the degree of motivation the individual has in complying with the important other's evaluation of whether the behavior should be performed ("motivation to comply" (m)). Analyses of these beliefs were used to predict teaching behavior: currently teaching fresh vegetable food safety (Behavior (B)), intending to teach fresh vegetable food safety (Behavioral Intention (BI)), and neither currently teaching nor intending to teach fresh vegetable food safety to clients/patients $(\operatorname{Neither}(\mathrm{N}))$.

The Theory of Planned Behavior was used to determine registered dietitian's personal characteristics and beliefs that predict: currently teaching fresh vegetable food safety (Behavior (B)), intending to teach fresh vegetable food safety (Behavioral Intention (BI)), or neither intending to teach nor currently teaching fresh vegetable food safety $($ Neither $(\mathrm{N}))$. By identifying and understanding these personal beliefs and characteristics, food safety curriculum may be designed to impart more valuable and effective messages to RDs about the importance of understanding and teaching fresh vegetable food safety. By providing the right kind of education, which focuses on the beliefs that actually predict whether RDs teach or intend to teach fresh vegetable food safety, they may then be more inclined to teach this information to their clients/patients. 


\subsection{Research Question and Objectives:}

A priori, we speculated there would be three subsamples within our sample: currently teach, plan to teach, and neither plan or currently teach. Because we added the third dependent variable and because only one question was asked to determine to which group the RD belonged, we created one multinomial dependent variable and a separate binary dependent variable. The addition of neither $(\mathrm{N})$ in the multinomial dependent variable will be used to account for RDs who neither currently teach fresh vegetable food safety nor plan to teach fresh vegetable food safety. Furthermore, we hypothesized that the willingness to teach, intend to teach, or neither teach nor intend to teach about fresh vegetable food safety is a function of RD's personal beliefs regarding teaching fresh vegetable food safety and/or their personal characteristics. The objective of this study was to identify the variables within a RD's personal beliefs about teaching fresh vegetable food safety, and their personal characteristics, that predict their teaching behavior related to teaching clients/patients about fresh vegetable food safety.

\subsection{Hypotheses:}

1). The multinomial dependent variable (Behavior (B), Behavior Intention (BI), or Neither (N)) will be significantly predicted by Perceived Behavioral Control (PBC), Attitude (Atd), and Subjective Norm (SN).

H1) $\log (\mathrm{BI} / \mathrm{B})=\beta_{0}+\beta_{1}(\mathrm{PBC})+\beta_{2}(\mathrm{Atd})+\beta_{3}(\mathrm{SN})+$ Error

H2) $\log (\mathrm{BI} / \mathrm{N})=\beta_{0}+\beta_{1}(\mathrm{PBC})+\beta_{2}(\mathrm{Atd})+\beta_{3}(\mathrm{SN})+$ Error 
H3) $\log (\mathrm{B} / \mathrm{N})=\beta_{0}+\beta_{1}(\mathrm{PBC})+\beta_{2}(\mathrm{Atd})+\beta_{3}(\mathrm{SN})+$ Error

2) Perceived Behavioral Control (PBC) will be the better predictor of Behavior (B), as a binary dependent variable (Behavior (B)), or (Behavior Intention (BI)/Neither $(\mathrm{N}))$.

Note: The binary dependent variable was created by recoding "neither" and "intend to teach" as 0 , and "currently teach" as 1 . 


\section{CHAPTER 2}

\section{REVIEW OF LITERATURE}

\subsection{Food Safety Trends and Registered Dietitians}

The centralization of the United States' food supply, coupled with current marketing trends, has created a situation where consumer fresh vegetable food safety knowledge is necessary (2). Unless consumers understand safe food-handling practices for the home, they may not benefit from the food safety prevention strategies of the food, beverage, and agricultural industries, and by the federal regulatory agencies (14). Research indicates consumers are not aware of their responsibilities to protect themselves from foodborne illness, nor are they taking the

proper preventative measures (14). Registered dietitians, who provide dietary advice to clients/patients, have many opportunities to provide fresh vegetable food safety information. Educators of RDs are in need of more effective ways to teach fresh vegetable food safety information so that RDs will learn the appropriate information 
and then pass it on to their clients/patients, the consumers of the produce being sold in America.

American's hectic and convenience-driven lives have caused more reliance on easily portable, potentially contaminated foods, including fresh produce such as baby carrots, pre-sliced apples, or homemade salads that could be held un-refrigerated in cars, purses, gym bags and work desks for extended periods of time (14). In addition, the centralized food system, which The United States has been adopting for the past several years, lends more opportunities for widespread contamination and increased complexity in tracing the pathogen of interest (4). As Jennifer Wilkins, $\mathrm{PhD}, \mathrm{RD}$ stated, "we have lost our connection to the land" (4). When people buy food at the grocery store they rarely have a clue where it is from or how it got there. Case in point, several different companies could potentially provide the contents for mixed greens; one company may provide the spinach, another the romaine, and yet another company might provide the iceberg lettuce. These mixed greens are then bagged by different processors, marketed under several brands, and distributed throughout the United States and beyond. This centralized food system, which the United States has been adopting for the past several years, lends more opportunities for widespread contamination and it decreases the traceability of pathogens to their source (4).

These marketing trends create a greater need for food safety knowledge among people who handle and prepare foods, especially consumers. Consumers rarely realize that once they have purchased a fresh vegetable that safety is in their own hands (14). The importance of protecting fresh produce from physical damage around the time of harvest is a way to improve the safety of fresh vegetables and to 
prevent pathogens like E.coli $\mathrm{o} 157: \mathrm{H} 7$ from attaching to the produce (15). This is the producer's responsibility, but the consumer should know that pre-washed and/or packaged produce must still be handled with care, as the efficacy of the type of wash used depends on factors such as contact time and the ability of certain pathogens to adhere to the vegetable. Once at home, or away from the place of purchase, it is the consumer's responsibility to prevent post-packaging proliferation by handling and storing the produce appropriately (16). Consumers need to become more educated in food safety, and to start practicing food safety more often, in order to protect themselves from foodborne illness.

Food safety is becoming more important and it is now one of the Department of Health and Human Services' and the United States Department of Agriculture's Dietary Guidelines For Americans (5). These guidelines were created to provide advice to people on how to promote health and reduce chronic disease risk (5). Although the guidelines have had a positive impact on the amount of vegetables being consumed for the purposes of health and chronic disease prevention, market research indicates gaps in consumer awareness and understanding of the risk of foodborne illness that could be attributed to the consumption of fresh produce (14). A study asked 1000 people how likely they were to get foodborne illness from foods such as chicken, pork, beef and fresh fruits and vegetables. The percentage of people who indicated they were either "very likely" or "likely" to become ill from consuming contaminated fresh fruits and vegetables was $4 \%$, compared to $89 \%$ who felt they were "very likely" or "likely" to become ill from consuming contaminated chicken (17). Another survey reported that $76 \%$, out of 4900 consumers, "always" 
thoroughly sanitize food preparation surfaces before they prepare fresh produce or meat, although 94\% said they knew it was important (18).

Recently the International Food Information Council (19) published results of a survey that was administered via the web to 1064 Americans eighteen years or older. This survey was designed to determine consumer's attitudes towards food, nutrition, and health. Included in this survey were questions related to food safety and food handling procedures. The results indicated $59 \%$ of Americans are confident in the safety of the U.S food supply, thus indicating that about forty percent of Americans are not confident in the U.S food supply. Additionally, about $95 \%$ of Americans claim to take at least one food safety precaution when cooking, preparing, and consuming food. Among those precautions were washing hands, which $87 \%$ claimed to do when handling food. However, smaller proportions of Americans are taking other important precautions such as using a different, or freshly cleaned, cutting board between types of food (50\%). When asked who they believe to be responsible for food safety, many perceived it as a shared responsibility among food services, industries, farmers, and the government, but only $41 \%$ agreed that it was partially the responsibility of the consumers. The majority agreed to not facing any obstacles to handling food safely (58\%), but still 19\% said they lack the needed information to handle food safely and $17 \%$ said they don't have enough time.

The increased incidence of fresh vegetable-related foodborne illness, and the lack of knowledge among consumers, both have implications for dietetics practice. Registered dietitians work in hospitals, long-term care facilities, sports nutrition and corporate wellness programs, food and nutrition-related businesses and industries, 
community and public health settings, universities and medical centers, research areas, and private practice (20). Dietitians who work in foodservice management and hospitality management must stay current on food safety regulations and trends to prevent passing pathogens from food to consumers. Just as important, dietitians who work as consultants and who are involved in client/patient education should also be aware of current food safety recommendations and consumption trends. Consultant dietitians are spokespeople who often consult based on The Dietary Guidelines for Americans, and they would like their clients/patients to have faith in the food supply so that they are not hesitant when purchasing or eating fresh vegetables (4). Even giving advice as simple as rinsing fresh vegetables and/or using a brush to clean fresh vegetables could be effective and important (4).

There are several reasons why RDs are consumers' link to food safety information. First, RDs have access to at-risk consumers and collectively work with all segments of the food chain. They also have the skills that allows for the development of influential educational messages to change food-handling behavior in the kitchen, foodservice establishments and supermarkets. Other important reasons that may be overlooked are that RDs have access to media outlets from which important food safety messages can be conveyed, they can mold food safety policy through voicing their legislative opinions, RDs have the entire American Dietetic Association with whom to collaborate and identify, and they can create or participate in cooperative projects to establish themselves as food safety leaders (14). 
Food and nutrition professionals, such as RDs, need to continue developing their knowledge of food safety and the rapidly changing food supply in order to provide appropriate information to their clients/patients (21). Registered dietitians are required to complete continuing professional educational requirements to maintain their status as an RD (22). There are opportunities for educators of dietitians, who plan and create education materials and programs for dietitians, to teach fresh vegetable food safety and to stress the importance of dietitians teaching fresh vegetable food safety to their clients/patients. These educators are in need of creative ideas on how to incorporate fresh vegetable food safety information into their curriculum for RDs in a way that allows for the appropriate message to get across effectively and consistently. As the field of food safety rapidly changes, teaching methods need to continue to evolve to meet the needs of the RDs and to impart the most effective messages (21). As a part of their education RDs should be aware of the importance of food safety for every sector of the dietetic field, not just those working in food service. For example, RDs who are considered consultant dietitians, and who provide nutrition education to clients and/or patients in various different settings, should be made aware of the importance of utilizing opportunities to incorporate fresh vegetable food safety information in their one-on-one consultations and to focus on information that is specific to the client/patient's demographics and personal needs (21).

There is little data available about how many RDs actually teach fresh vegetable food safety. Of the available data, only one unpublished study provided estimates of how many RDs actually teach food safety, but not specifically fresh 
vegetable food safety (personal communication, Janet Buffer). The study surveyed two hundred and sixty-seven RDs who regularly work with one of three highly susceptible populations: pregnant women, the elderly, and the immunecompromised. The RDs were asked to choose one of three options; "yes, I teach food safety", "I teach food safety sometimes", or "no I do not teach food safety". Out of 127 RDs who regularly work with pregnant women, ten reported they do not teach food safety, sixty-four reported they teach food safety sometimes, and fiftythree (42\%) said they teach food safety regularly. Of the 212 RDs who regularly work with elderly individuals, 63 said they do not teach food safety, 127 RDs said they teach food safety sometimes, and $21(9.9 \%)$ said they teach food safety regularly. Of the 198 RDs who regularly worked with immune-compromised individuals, 32 reported not teaching food safety, 108 reported they sometimes teach food safety, and $58(29.3 \%)$ reported regularly teaching food safety. These results provide an estimate of the number of RDs who teach fresh vegetable food safety. Considering these are the reports from RDs who regularly work with immunecompromised individuals, it can be inferred that the number of RDs who teach fresh vegetable food safety to their clients/patients, who aren't necessarily of increased susceptibility, is most likely less.

\subsection{The Theory of Planned Behavior}

The Theory of Planned Behavior (TPB) is an extension of The Theory of Reasoned Action (TRA). The Theory of Reasoned Action was designed to predict 
human Behavior (B) and to identify the factors that lead to Behavioral Intentions (BI) (10) (Figure 1.1).

The difference between the two theories is that The Theory of Reasoned Action (TRA) deals with behaviors over which people possess complete volitional control, or ones they have the conscious choice to do. The Theory of Planned Behavior (TPB) $(9,10,11)$ accounts for behaviors over which a person has incomplete volitional control or one that they may not have the conscious choice to do, as the successful performance of the behavior depends on the person's control over certain external and internal factors (10).

When a behavior is under volitional control a person's behavioral intentions are said to capture the motivational factors that can impact whether the person does the behavior. In other words, a person's behavioral intentions are indications of how hard they are willing to try to do the behavior and how much effort they are willing to put forth (10). When dealing with a volitional behavior it is expected that a person will do what they intend to do, and thus they will follow through with the behavior. In a summary of past studies used the Theory of Reasoned Action to find correlations between behavioral intentions and volitional behaviors, correlations ranged from .72 for smoking marijuana to .96 for having an abortion $(\mathrm{p}<0.05)(10)$. Each of the studies indicated that behavioral intentions had high compatibility with the behavior in terms of the target, action, context and elements of time (10).

According to both the TRA and the TPB, behavior is a function of salient beliefs that are related to the behavior in question. People could hold many beliefs about any given behavior but in a given instance can only attend to a small number 
of beliefs, which are their salient beliefs. These beliefs are formed as a result of either direct observation, self-generation via inference processes, or indirectly by accepting outside source information such as television, newspapers, books, magazines, or other outside sources (10). There are three types of salient beliefs, which influence the belief variables of the TRA and the TPB; "control beliefs" (c), and are unique to the TPB, "behavioral beliefs" (b) and "normative beliefs" (n). "Control beliefs" influence the Perceived Behavioral Control (PBC), "behavioral beliefs" influence Attitudes (Atd) towards the behavior, and "normative beliefs" influence Subjective norm (SN).

For behaviors that are under one's volitional control the Theory of Reasoned Action should be utilized. Of the two belief variables that make up The Theory of Reasoned Action and that are said to precede formation of behavioral intentions, one is more personally influenced and the other more socially influenced. The personal belief variable is the individual's Attitude (Atd) towards the behavior, and the social belief variable is called Subjective Norm (SN). An individual's attitude is his or her positive or negative evaluation of performing the particular behavior. Subjective norm are described as beliefs that important groups or individuals approve or disapprove of performing the behavior. Both of these belief variables are also part of the Theory of Planned Behavior.

When a behavior is non-volitional, behavioral intentions take on a whole new meaning. When one has to potentially deal with internal or external factors, their behavioral intentions to perform a behavior are thought of more as intentions to try performing the behavior, rather than actually doing the behavior (10). The 
performance of a non-volitional behavior, in many instances, depends on both motivation and adequate control over the specific behavior (10).

For the many behaviors that are not under one's own volitional control, The Theory of Planned Behavior should be utilized. The Theory of Planned Behavior proposes three, rather than two, conceptually independent belief variables that lead to behavioral intention, and thus predict the willingness of a person to try the actual behavior. The belief variable that is unique to the Theory of Planned Behavior is known as Perceived Behavioral Control (PBC), which is the person's perception of ease or difficulty in performing the behavior. Thus, the Theory of Planned Behavior does not only assess one's attitudes and subjective norm, but goes further to assess the extent to which the individual is capable of initiating control over the particular non-volitional behavior (10).

To summarize, The Theory of Planned Behavior begins at the initial level, where volitional Behavior (B) is assumed to be determined by a person's Behavioral Intention (BI) (10). A person's Behavioral Intention (BI) to perform a Behavior (B) should capture their motivational influences and should indicate how hard they are willing to try and how much effort they are willing to put forth in order to perform a behavior (9). At the next level the Behavioral Intentions (BI) are said to be explained by an individual's Perceived Behavioral Control (PBC), Attitudes (Atd) towards the behavior, and Subjective norm (SN). The third level accounts for Perceived Behavioral Control (PBC), Attitudes (Atd), and Subjective norm (SN) in terms of one's salient beliefs about their control over the behavior, the consequences of 
performing the behavior, and their normative expectations of referent others, respectively $(9,10,11)$.

\subsection{Perceived Behavioral Control}

The Theory of Planned Behavior is used for predicting non-volitional behaviors, where a person's behavioral intentions and/or behavior depends on the person's control over various factors. Perceived Behavioral Control (PBC), the additional belief variable that creates the Theory of Planned Behavior, refers to the anticipated ease or difficulty of performing a behavior $(9,10,11)$. The degree of control a person has over a given behavior can be influenced by internal factors and external factors. Internal factors refer to a person's intentions to do a specific behavior, but upon trying to do so he or she realizes that they are either lacking the needed information, skills, or abilities, or their emotions, stress or compulsions prevent them from going through with the behavior (10). Alternatively, external factors refer to luck, opportunity, and dependence on others that may cause a person to not perform a behavior, despite having intended to do so (behavioral intention) (10). These factors basically comprise outside circumstances that may facilitate or hinder the performance of a behavior. Both internal and external factors can potentially prevent or entail the performance of a behavior and can have an effect on behavioral intention and/or behavior.

Perceived behavioral control deals with the concept of internal-external locus of control, which is the extent that an individual believes they are able to control their own behavior $(10,23)$. Perceived behavioral control is determined by a specific type 
of salient belief referred to as "control beliefs" (c), which can be formed by past experience with the behavior, second-hand information about the behavior, experiences of friends and family with the behavior, and other factors that increase or decrease the person's perceived difficulty or ease in performing the behavior (9). The theory postulates that the more resources and opportunities, and the fewer obstacles anticipated the greater should be a person's PBC. In other words, the more control a person feels they have over completion of a behavior, the more motivated they are to try completing the behavior.

Perceived behavioral control reflects both past experience with the behavior and the possibility of obstacles, such as the external and internal factors, which may hinder the actual act of the behavior (10). People who believe they do not have the opportunity or the resources to perform a certain behavior are unlikely to form strong behavioral intentions to perform the behavior, regardless of having favorable attitudes towards the behavior or believing that referent others would want them to perform the behavior (subjective norm). On the contrary, if people believe that their outcomes and their ability to complete a certain behavior are under their own control, they may be more likely to form strong behavioral intentions to perform the behavior.

The Theory of Planned Behavior postulates a direct link between PBC and behavioral intention, which does not depend on attitudes or subjective norm, but it also suggests a direct link to behavior, independent of behavioral intention, attitudes, or subjective norm. This direct link forms presumably to the extent that PBC can reflect actual control with a certain degree of accuracy. Therefore, if a person feels they have control over the completion of a behavior, and they are thus motivated to 
do the behavior, whether or not they actually succeed in completing the behavior is based on how accurate their PBC reflected their actual control. There are some situations, such as those in which the individual has very little information about the behavior, where $\mathrm{PBC}$ is not especially realistic. An example is when requirements or available resources have changed, or new and unfamiliar elements have been presented. The relationship between PBC and behavior is only expected to emerge when there is an agreement between the person's perceptions of control and their actual control over the behavior.

One study used a questionnaire that was composed of questions related to the TPB, which was administered at two points in time. The questionnaire assessed the intentions of students to get an " $\mathrm{A}$ " in a course (behavioral intention) and then later their actual attainment of the " $\mathrm{A}$ " (behavior) (23). The initial questionnaire was given before students had received any grades in the particular class. At this time the students really had very little knowledge about the professor, how he/she graded, how much work was actually involved in the class, and what obstacles may be presented throughout the course. Therefore any measurement of PBC was expected to not reflect actual control very well. This assumption was valid, as the addition of PBC to TRA did nothing to improve prediction of behavior. The second assessment of the experiment was administered near the end of the semester after the students had received plenty of feedback and information regarding their performance. After controlling for behavioral intentions, the relation between PBC and actually getting an "A" in the class was significant $(\mathrm{r}=0.38, \mathrm{p}<0.01)$. The addition of $\mathrm{PBC}$ significantly added to the predictive power of the model by increasing the $\mathrm{R}^{2}$ from 
0.49 to 0.64 for prediction of behavioral intentions, and from 0.39 to 0.45 for the prediction of behavior $(\mathrm{p}<0.01)$.

In a review of fifty-six studies that applied the TPB to health-related behaviors it was found that the theory accounted for an average of $41 \%$ of the variance in behavioral intentions and $34 \%$ of the variance in actual behavior. Perceived behavioral control was often found to be a significant co-predictor of Behavioral Intentions (BI) and Behavior (B) (24). This same review looked the added contribution of perceived behavioral control in predicting behavior above behavioral intention. When findings were significant, the additional contribution of perceived behavioral control above behavioral intention was $11.5 \%$, on average. These results imply that the TPB is reliable for predicting non-volitional healthrelated behaviors, and is superior to the TRA under those conditions.

The current research deals with a non-volitional behavior: RDs teaching fresh vegetable food safety to their clients/patients. Internal factors, such as not having the proper knowledge to teach the information, or external factors such as lack of teaching materials, may prevent the RD from teaching fresh vegetable food safety, despite having intended to do so. Conversely these internal and external factors may also allow for the dietitian to teach fresh vegetable food safety (Behavior (B)), despite not intending to teach (Behavioral Intention (BI)). For example, an RD might read an informative article regarding fresh vegetable food safety and decide to discuss the article with a client/patient, despite not having intended to do so prior to reading the article. Another example would be if an RD's employer randomly provides a handout for fresh vegetable food safety, which he or recommends handing out and discussing 
with clients/patients. In this case, the RD might choose to teach fresh vegetable food safety despite not having intended to do so. Internal and external factors could play a role at any time after behavioral intention have been stated, and thus could potentially lead to changes in behavior (24).

Determining PBC can be measured either directly or indirectly, but it was stated that most studies have used the direct approach (25). Both measurements of PBC are meant to capture the perceived facilitating and inhibiting effects of all foreseeable control factors that may affect performance of the behavior. Determining PBC directly entails asking questions about a person's capability to perform a behavior (25). These questions can include anything from the ease or difficulty in performing a behavior to the amount of control the person feels they have in controlling whether they do the behavior.

The alternative method, which is the indirect method, is more complex and it entails generating a list of factors that the person believes may make completing the behavior easier or more difficult. The next step is to ask the person to indicate the likelihood of a given control factor being present, followed by indicating the extent to which the particular control factor has the ability to facilitate or impeded the performance of the behavior.

Studies that used both direct and indirect measurements for PBC calculated internal reliabilities among the $\mathrm{PBC}$ items. The $\mathrm{PBC}$ items contributed to internal reliabilities of 0.81 for participating in regular physical activity (26), and 0.90 for taking a multi-vitamin everyday for three weeks (27). An adequate measure of internal reliability is . 70 or above; 1.0 is the maximum (9). These results indicate the 
direct and indirect methods of measuring PBC are reliable, and thus either method is appropriate.

\subsection{Attitude}

In addition to $\mathrm{PBC}$ another belief variable that is part of the $\mathrm{TPB}$, is an individual's Attitude (Atd). Attitude refers to a person's positive or negative evaluation of performing a particular behavior. Attitudes are formed depending on the specific salient belief (beliefs specific to the behavior) one holds about the behavior (15). Associating the behavior with certain attributes forms salient beliefs about a behavior. The attributes, either positive or negative, become linked to the behavior in the individual's mind and thus a positive or negative attitude is formed. In order to apply this to the formation of attitudes toward a behavior, the strength of the individual's salient beliefs should be observed. The person's salient beliefs about the behavior are termed their "behavioral beliefs" (b) (10). Each behavioral belief links the behavior to a certain outcome or attribute, such as cost or time spent to perform the behavior. The person's "outcome evaluation" (e) is also determined in order to evaluate the positive or negative perception of the particular behavioral belief.

The person's attitude towards the behavior can be determined directly or indirectly. Determining attitudes indirectly considers the strength of the individual's "behavioral beliefs" and the "outcome evaluation" of those beliefs (10). The strength of the belief is the subjective probability that the object has, or will result in, the attribute in question. In order to determine one's attitude in regards to an object or behavior, the strength of each "behavioral belief" is multiplied by the "outcome 
evaluation" of the belief attribute, and the resulting values are summed (Figure 2.1). This is termed Fishbein and Aizen's Expectancy-Value Model, and is said to be directly proportional to attitude (10). Icek Aizen, the creator of The Theory of Planned Behavior, reports on his website that the statistical average may be used instead of the sum of the scores, as long as the same set of beliefs are assessed for each respondent. This is possible because the average is a simple linear transformation of the sum (28).

$$
\mathrm{A} \propto \sum_{i=1}^{n} \mathrm{~b}_{\mathrm{i}} \mathrm{e}_{\mathrm{i}}
$$

Figure 2.1 Fishbein and Aizen's Expectancy-Value Model (9).

This is the equation that is used to indirectly determine a person's attitude towards a specific behavior. In this equation "A" refers to attitude, which is directly proportional $(\propto)$ to the summative belief index. The summative belief index is the resulting product of "b", which refers to the person's "behavioral beliefs", and "e", which refers to the person's "outcome evaluation", summed over $n$ behavioral beliefs.

Therefore, a person who believes that important outcomes are likely to result or that unimportant outcomes are unlikely to result from performing a behavior will hold a favorable attitude towards performing the particular behavior. In contrast an individual who believes that unimportant outcomes will results or that important outcomes won't result from performing a behavior will understandably hold an unfavorable attitude toward the behavior. An alternative way to measure attitudes would be to directly assess a person's attitude by asking a set of questions and simply summing the scores. Aizen's Expectancy-Value Model has been shown to have high 
correlations with the direct assessment of attitude (10). Three studies, for example, used TRA to assess female's attitudes towards using birth control pills, another assessed attitudes about choices of career orientation, and another study assessed attitudes about the benefits of exercise $(10,24)$. The correlations between the direct assessment of attitude and Aizen's indirect, belief based assessments were $0.79,0.81$, and 0.52 , respectively.

\subsection{Subjective Norm}

The third belief variable that is part of the TPB and the TRA is Subjective Norm (SN). Subjective norm are also determined by salient beliefs, but salient beliefs of a different kind than perceived behavioral control and attitude. These types of salient beliefs are called "normative beliefs" (n) and are described as beliefs that important groups or individuals approve or disapprove of performing the behavior. These groups or individuals are known as referent others. Generally speaking, if an individual feels that a referent other thinks they should perform a specific behavior, perceived social pressure will often cause them to do so. On the other hand, if an individual feels that a referent other thinks they should not perform a specific behavior, perceived social pressure will often cause them to refrain from the specific behavior. Subjective norm account for whether the referent other evaluates the behavior in a positive or negative way and the degree to which the person in question is "motivated to comply" with the important other's evaluation of the behavior (10).

A person's subjective norm about a particular behavior can be determined indirectly or directly. Direct measurements of subjective norm are determined by 
asking individuals the extent to which their referent others would approve or disapprove of them performing a specific behavior. One or multiple questions can be asked, and then they are summed to determine SN. Indirect measurements of SN are determined by assessing the strength of a person's normative beliefs and their motivation to comply with those beliefs. The results of their "normative belief" scores and the corresponding "motivation to comply" scores are multiplied for the SN. If multiple "normative belief" and "motivation to comply" items are assessed, the product scores are summed (Figure 2.2) (10). Taking the statistical average of the scores is also an option (28).

$$
\mathrm{SN} \propto \sum_{i=1}^{n} \mathrm{n}_{\mathrm{i}} \mathrm{m}_{\mathrm{i}}
$$

Figure 2.2. Equation for the Indirect Measure of Subjective Norm (9).

This is the equation that is used to indirectly determine a person's subjective norm regarding a specific behavior. In this equation "SN" refers to subjective norm, which is directly proportional $(\propto)$ to the resulting product of " $n$ ", which refers to the person's normative beliefs, and " $m$ ", which refers to the person's motivation to comply, summed over $n$ normative beliefs.

\subsection{Scaling and Scoring}

Various differences exist in the scaling and scoring techniques used to determine each of the three belief variables. Five-point Likert scaling was used in the current study but it is evident from the literature that seven-point Likert scaling is used most often. However, studies exist using five-point Likert scaling and the theory does not suggest a specific type of scaling. In the study by Griffin et al. (8), it 
was indicated that the five-point Likert scale was easier for the respondents to understand, however they were interviewing over the telephone and relied on auditory comprehension. According to Aizen the number of points used on the Likert scale is at the discretion of the researcher, depending on his or her preferences (28).

Techniques for optimal scoring have been suggested by Icek Aizen (9). Scoring techniques for perceived behavioral control and subjective norm were based on the review article by Aizen, which indicated that either type of scoring, unipolar or bipolar, could be applied with equal justification (9).

For the attitude belief variable scoring both "behavioral beliefs" and "outcome evaluations" in a bipolar fashion allows for positive values to be yielded when a participant believes that important outcomes would result from the behavior or that unimportant outcomes are unlikely to result, and negative values to be yielded when a participant believes that unimportant outcomes would result from the behavior or that important outcomes are unlikely to result. Aizen reported that using bipolar scoring for the attitude variable construct greatly improves correlations between the variable and behavior, when compared to studies that use unipolar scoring for "behavioral belief" and bipolar for "outcome evaluation" (9). Studies using the TPB in relation to outdoor jogging or running, mountain climbing, and boating, showed correlations of $0.34,0.25$, and $0.24(\mathrm{p} \leq 0.05)$ respectively, among the direct way of assessing attitudes and the indirect way using unipolar and bipolar scoring (9). These same studies showed correlations of $0.35,0.51$, and $0.44(\mathrm{p} \leq 0.01)$, respectively, when bipolar scaling was used for both "behavioral beliefs" and "outcome evaluations". Either way is acceptable, however. Attempts are still being made to improve the 
correlation between this indirect method for evaluating attitude and the more direct method (9). A majority of the studies used the indirect method, so the current study uses the indirect method as well.

\subsection{Review of Past Studies}

The Theory of Planned Behavior has been tested within several different contexts involving incomplete volitional behaviors. A review of the literature indicated that several authors provide support for the use of the Theory of Planned Behavior in predicting health-related behavioral outcomes. Studies were reviewed that looked at behavioral intention or behavior. Those that looked at both behavior and intention went a step beyond and tested the subjects twice, once to measure behavioral intention, and a second time at a later date to measure if they actually did the behavior. The following studies were completed to predict multiple healthrelated behaviors, including physician's delivery of preventive services (29), teachers' intentions to teach HIV/AIDS education (30), adolescent weight loss behavior (31), RD's intentions to teach about whole grains (32), older adult's behaviors related to consumption of fruits and vegetables (33), and employee's food handling behaviors (34). Each of these studies indicated that the components of the Theory of Planned Behavior significantly predicted Behavioral Intentions (BI) and/or Behavior (B).

The ability of the Theory of Reasoned Action to predict physician's prospective behavior regarding educating adolescents about sexually transmitted diseases was compared to that of the Theory of Planned Behavior to predict the 
same behavior (29). Educating adolescents about sexually transmitted diseases is a behavior of which physicians do not have complete volitional control, as there are internal and/or external factors that could get in the way of the behavior. Seven hundred and sixty five physicians, all board certified in family practice, participated in the study. Open-ended interviews were conducted prior to the study, with 20 physicians who helped identify salient beliefs that would help construct some of the questions for the questionnaire. The final questionnaire included questions regarding attitudes, subjective norm, and perceived behavioral control of the physicians in regards to teaching adolescents about sexually transmitted diseases. Attitudes and subjective norm were determined indirectly, and perceived behavioral control was determined directly. Behavioral intentions were assessed by asking the physicians to respond on a scale from zero to 100 as to the percentage of adolescents they intended to educate over the next five to six months. Behavior was assessed two times, once before the questionnaire was given and once six months after it was given. Multiple regression analysis was done to determine the variance explained by the Theory of Reasoned Action in predicting behavioral intention.

The researchers found that the constructs of the TRA explained $39 \%$ of the variance in behavioral intention $\left(\mathrm{R}^{2}=0.39, \mathrm{p} \leq 0.001\right)$. When $\mathrm{PBC}$ was added to the model, the model was more predictive of behavioral intention $\left(\mathrm{R}^{2}=0.52, \mathrm{p} \leq 0.001\right)$. Attitudes, subjective norm, and perceived behavioral control each had significant effects on behavioral intention: $\beta=0.11, p \leq 0.001, \beta=0.21, p \leq 0.001$, and $\beta=0.37$, $p \leq 0.001$, respectively. Considering that the behavior in question was not completely 
volitional, these results were to be expected, as they validated the use of the TPB for incomplete or non-volitional behaviors.

Further analysis was done to test the relationship of the two models to the actual behavior. Hierarchical multiple regression was used with the full set of TRA variables and found that significant variance in physician's behavior was explained $\left(\mathrm{R}^{2}=0.61, \mathrm{p} \leq 0.001\right)$. A model using all constructs of the Theory of Planned Behavior was significant as well $\left(R^{2}=0.63, p \leq 0.001\right)$. The change in $R^{2}$ was significant $(0.11, \mathrm{p} \leq 0.001)$ after the addition of PBC. Significant effects on behavior were found for subjective norm $(\beta=0.19, p \leq 0.001)$ and perceived behavioral control $(\beta=0.36, p \leq 0.001)$. After a simultaneous regression of behavior on attitudes, subjective norm, behavioral intentions, and perceived behavioral control, the beta weight for PBC was significant $(\beta=0.18)$. This indicated a direct effect of $\mathrm{PBC}$ on behavior, independent of behavioral intentions, subjective norm, and attitudes. Additionally there was a small but significant direct effect of subjective norm on behavior, despite the model suggesting $\mathrm{PBC}$ as the only independent variable to have direct effects on behavior. These results indicated the ability of the TPB to predict whether a physician will teach or intend to teach adolescents about sexually transmitted diseases.

The Theory of Planned Behavior was compared to the Theory of Reasoned Action in examining the factors that influence elementary school teachers' decisions regarding teaching AIDs education and to predict their behavioral intention to teach about HIV/AIDs to their students (30). One hundred and ninety-eight elementary school teachers answered self-administered questionnaires, which contained both 
direct and indirect measures of attitude, subjective norm, and perceived behavioral control. Salient belief questions, in regards to elementary school HIV/AIDs education, were derived from persons who resembled the population of interest and were used to determine behavioral beliefs. Interviews were conducted with 12 teachers in order to create valid questions concerning "behavioral beliefs", "normative beliefs", and "control beliefs". These interviews were later used to create the questions pertaining to attitude, subjective norm, and perceived behavioral control.

Results indicated that each of the directly derived measurements significantly correlated with their corresponding indirectly derived measurement, which provided validity for the use of either type of measurement in determining the belief variables of the model. Multiple linear regression analysis was conducted using constructs of the TRA. Attitude and subjective norm accounted for $47 \%$ of the variance in the teachers' behavioral intention to provide HIV/AIDS education $\left(\mathrm{R}^{2}=0.47, \mathrm{p} \leq 0.001\right)$. Subjective norm contributed the greatest weight with a regression coefficient of 0.47. When perceived behavioral control was added into the multiple regression analysis, the variables accounted for $64 \%$ of the variance in teachers' behavioral intentions $\left(\mathrm{R}^{2}=0.64, \mathrm{p} \leq 0.001\right)$. Perceived behavioral control had the largest regression coefficient $\left(\mathrm{R}^{2}=0.71, \mathrm{p} \leq 0.001\right)$, which signified the importance of $\mathrm{PBC}$ in aiding the prediction of whether or not a teacher intends to provide HIV/AIDS education. Results from this study support the approach for the use of the TPB in the current study, as HIV/AIDs education is a behavior over which there is incomplete volitional control. 
Schifter and Aizen (31) applied the TPB to the prediction of female college student's weight loss intentions, and actual weight reduction. There were two stages to this study. The first stage included weighing the subjects and having them fill out a questionnaire, which directly assessed attitudes, subjective norm, and perceived behavioral control. Likert scales were used for Atd and SN. Perceived behavioral control was measured by asking participants to indicate on a scale from zero to 100 the likelihood of successful weight loss over a six-week period and their estimates of successful weight loss after their attempt to loose weight. Behavioral intention was measured using several seven-point scales, on which the women indicated their intentions to try to loose weight and the intensities of their decisions. Six weeks later for the second stage of the study the participants were weighed again as a way to measure actual behavior. Multiple regression analysis revealed that all three of the belief variables independently contributed to the prediction of behavioral intention to loose weight. Regression coefficients for attitudes, subjective norm, and perceived behavioral control were $0.79,0.17$, and 0.30 respectively $(\mathrm{p} \leq 0.01)$. Therefore, attitudes were the best predictor of intentions to loose weight. When analyzing behavior, $\mathrm{PBC}$ was the best and only single predictor of actual weight loss $\left(\mathrm{R}^{2}=0.41, \mathrm{p} \leq 0.01\right)$. Hierarchical multiple regression analysis was performed to examine predictability of weight loss. Behavioral intention and PBC were entered in the first step, followed by the interaction between the two. This was done to test the idea that successful attempts to loose weight require both motivation (behavioral intention) and adequate control over internal and external variables (PBC). There was a significant effect of $\mathrm{PBC}$ on weight loss (regression weight $=0.39, \mathrm{p} \leq 0.01$ ) 
and a slightly significant effect of the interaction term (regression weight $=0.20, \mathrm{p} \leq$ 0.10). These results indicated that the subjects with strong behavioral intention, positive attitudes about losing weight, and strong subjective norm about loosing weight only actually lost weight when they felt they had control over internal and/or external factors. Overall the TPB was successful in predicting behavioral intention and moderately successful in predicting actual behavior.

Most relevant to the current study was a study that used the TPB to explain the behavioral intentions of RDs to promote whole grains (32). Using a mailed survey, $776 \mathrm{RDs}$, all of whom were working in direct patient care, answered items that directly assessed their attitudes, indirectly assesses their subjective norm, and directly assessed their perceived behavioral control regarding promoting whole grains. It was determined by multiple logistic regression analysis that the model significantly explained about $28 \%$ of the variance in RD's intentions to promote whole grains $\left(\mathrm{R}^{2}=0.28, \mathrm{p} \leq 0.001\right)$. Subjective norm were the strongest predictor of behavioral intention ( $\mathrm{t}=10.50, \mathrm{P} \leq 0.001)$. Student's $\mathrm{t}$-tests are used to test the significance of simple regression weights and correlations, and certain statistical analysis programs compute t-values for each regression weight. Standardized beta calculations indicated that subjective norm were actually 11.9 times more important than attitudes, and 2.3 times more important than perceived behavioral control in terms of explaining RD's behavioral intentions to promote whole grains. Of the $97 \%$ of RDs who had intentions to promote whole grains, $89 \%$ indicated they wanted to comply with their subjective norm. Subjective norm measurements were based on whether the RDs felt that other health professionals had strong opinions about them 
promoting whole grains, and whether the RDs felt motivated to comply with those health professionals. Other interesting results were based on the answers from the PBC items. The few RDs who perceived barriers to teaching whole grains preferred to focus on other dietary changes that they felt were more important. Other reasons for perceived lack of control were having not enough time, and lack of materials to use with clients.

The Theory of Planned Behavior was applied to fruit and vegetable consumption among older adults (33). A cross-sectional questionnaire was given to 205 older adults (mean age $=77$ years) at senior centers in Minneapolis, Minnesota . Beliefs about fruits and vegetables were assessed using five-point Likert scales. Attitudes and perceived behavioral control were assessed directly, and subjective norm were assessed indirectly. Intention to consume five fruits and vegetables per day, the first dependent variable, was determined by summing the responses of two statements on the questionnaire (statements not provided). The second dependent variable, the actual number of fruits and vegetables consumed per day (behavior), was determined by directly asking how many fruits and vegetables the participants currently consumed each day. Multiple linear regression analysis was done to determine whether the independent variables predicted behavior. A significant $40 \%$ of the variance in intention to consume fruits and vegetables was explained by the Theory of Planned Behavior model $\left(\mathrm{R}^{2}=0.40, \mathrm{p} \leq 0.001\right)$. Additionally, the model explained a significant $18 \%$ of the variance in actual behavior $\left(\mathrm{R}^{2}=0.18, \mathrm{p} \leq 0.001\right)$. Attitudes and perceived behavioral control were the best predictors of behavioral intentions to consume five fruits and vegetables each day $(\mathrm{t}=4.77, \mathrm{t}=7.06$, 
respectively, $\mathrm{p} \leq 0.001)$. Perceived behavioral control directly affected behavior, whereas attitudes and subjective norm indirectly affected behavior through behavioral intention.

The relative impact of different influences on food handler's behavioral intentions to practice safe food handling at every occasion was evaluated using the Theory of Planned Behavior (34). A questionnaire was administered to 135 food handlers. Perceived behavioral control, subjective norm, and attitudes were all assessed indirectly. A final question was asked to determine the dependent variable of the study, the participant's intention to use safe food handling practices on every occasion during the following week. The researchers found that $45 \%$ of the variance in the intention to carry out safe food handling practices on every occasion was significantly accounted for by the Theory of Planned Behavior $\left(\mathrm{R}^{2}=0.45, \mathrm{p} \leq\right.$ 0.001). Subjective norm had the greatest effect on behavioral intention $(\beta=0.55, \mathrm{p} \leq$ $0.001)$, and predicted behavioral intention best $\left(\mathrm{R}^{2}=0.36, \mathrm{p} \leq 0.001\right)$. This suggested that other people's opinions about whether the food handler's should practice good hygiene had the most significant effect on their intentions to do so. Perceived behavioral control also had a significant effect on behavioral intention $(\beta=0.24, \mathrm{p} \leq$ $0.001)$, and significantly predicted behavioral intentions $\left(\mathrm{R}^{2}=0.25, \mathrm{p} \leq 0.001\right)$. Attitudes did not have a significant effect on behavioral intention $(\mathrm{P} \geq 0.05)$.

\subsection{External Variables}

Of the previous studies that included external variables in their survey/questionnaire some included them in the regression model and others did not. 
External variables, such as demographic variables, situational variables, or personal characteristics, are not considered to directly enter into the causal structure of the Theory of Planned Behavior (10). According to Aizen, the external variables will only relate to behavior in the sense that they influence the beliefs that ultimately lead to behavior. Therefore, the relationship between the external variables and behavior are said to be mediated by the three main belief variables. However, the theory is open to the inclusion of these external variables and in the review of the literature some studies did not control for these external factors, but others did. In the study that looked at elementary school teacher's behavioral intentions to teach HIV/AIDs education (30) three external variables contributed additional variance: grade taught (4.7\%), having had in-service training on AIDs education (2\%), and having taught the subject in the past (8\%). In the study that looked at older adult's consumption of five fruits and vegetables, the demographic variables were not included in the regression model, but living status, exercise, and vitamin use were all associated with fruit and vegetable consumption (33). In the study that looked at RD's intentions to promote whole grains, three external variables were assessed and significant variance was not additionally explained by those variables (32).

\subsection{Concluding Remarks}

Currently no study has used the Theory of Planned Behavior to determine RD's personal beliefs about teaching fresh vegetable food safety, and their personal characteristics that predict whether they currently teach or intend to teach or fresh vegetable food safety. The current study will, for the first time, determine if RD's 
teaching behavior is predicted by (a) Perceived Behavioral Control (perceptions of barriers to teaching fresh vegetable food safety and belief in one's ability to combat these barriers if they exist), (b) Attitude (beliefs that teaching fresh vegetable food safety will lead to positive or negative outcomes), or (c) Subjective norm (beliefs that important referents have about teaching fresh vegetable food safety and the registered dietitian's motivation to comply with those beliefs).

It is important to note that unlike any other study, this one used one multinomial dependent variable constructed from results of one question that asked whether the RD currently teaches, intends to teach, or does neither. Whereas most studies measure behavioral intentions, or behavior, or one and then the other, the current study measured both at the same time, and allowed the RDs to only report one teaching behavior.

Information learned from this study will be used to aid in the development of more successful and effective continued education, didactic education, and/or internship education regarding fresh vegetable food safety. By determining the personal beliefs and characteristics of RDs that predict teaching behavior, education materials can be designed around those factors to positively effect whether RDs teach their clients/patients about fresh vegetable food safety. 
CHAPTER 3

\section{REGISTERED DIETITIAN'S PERSONAL BELIEFS AND CHARACTERISTICS PREDICT THEIR TEACHING OR INTENTIONS TO TEACH FRESH VEGETABLE FOOD SAFETY}

\subsection{Introduction}

Most people associate foodborne illnesses with contaminated meat, poultry or dairy products, but the Center for Disease Control (CDC) reports a continuing emergence of pathogens and an increased proportion of bacterial outbreaks caused by fresh contaminated fruits and vegetables (2). Among the most popular fresh produce is fresh-cut salads, with a sales of $\$ 2.7$ billion per year (3). The current study focuses on the safety of fresh vegetables, specifically leafy greens and tomatoes, and whether or not dietitians, as representatives of health professionals, provide their clients/patients with information about the safety of fresh vegetables.

Registered dietitians (RD) are a reliable source for information on, and often

give advice about consuming fresh vegetables, therefore they should also know about 
fresh vegetable food safety (4). RDs learn about food safety, including fresh vegetable food safety, as part of their undergraduate curriculum and are required to have the ability to "apply safety principles related to food, personnel and consumers" and "develop and deliver products, programs or services that promote consumer health, wellness and lifestyle management merging consumer desire for taste, convenience and economy with nutrition, food safety and health messages interventions" (7).

In relation to fresh vegetables, educators of RDs should focus on prevention strategies such as the importance of removing brown areas from fresh vegetables, removing the outermost leaf from a head of lettuce, drying fresh vegetables before putting them in storage, and properly covering the surface of fresh vegetables after they have been cut $(1,3)$. Risk perception researchers have concluded that risk communication works best if there is a greater focus on illuminating the process that may ultimately cause people to adapt certain behaviors, rather than assuming that risk information does something to an individual (8). This concept can be incorporated into the fresh vegetable food safety education materials for RDs so that they develop a better understanding of some important fresh vegetable food safety concepts and thus may be more likely teach their clients/patients about fresh vegetable food safety.

The current study used a descriptive, cross-sectional survey design. The survey was composed of items that were derived from a review of the literature on Icek Aizen's Theory of Planned Behavior (TPB) $(9,10,11)$ (Figure 1), with specific focus on the studies done by Griffin et al. $(12,13)$. The TPB was used to determine 
RD's personal beliefs about teaching fresh vegetable food safety, and their personal characteristics that predict whether or not they teach their clients/patients about fresh vegetable food safety. Salient beliefs, which are beliefs specific to the behavior in question, were measured in regard to teaching clients/patients about fresh vegetable food safety, and were captured in three independent belief variables; Perceived Behavioral Control (PBC), Attitudes (Atd), and Subjective norm (SN).

Perceived behavioral control (PBC) refers to the anticipated ease or difficulty of performing a behavior, which is determined by "control beliefs" (c) $(9,10,11)$. Attitudes (Atd) refer to the person's beliefs about the outcomes of the behavior ("behavioral beliefs" (b)) and their positive or negative evaluations of those particular beliefs ("outcome evaluations" (e)). Subjective Norm (SN) refers to whether an individual thinks that others important to them (referent others) believe the behavior is something that he or she should perform ("normative beliefs" (n)), and accounts for the degree of motivation the individual has in complying with the referent other's evaluation of whether the behavior should be performed ("motivation to comply" (m)). Analyses of these beliefs were used to predict teaching behavior: currently teaching fresh vegetable food safety (Behavior (B)), intending to teach fresh vegetable food safety (Behavioral Intention (BI)), and neither currently teaching nor intending to teach fresh vegetable food safety to clients/patients (Neither $(\mathrm{N}))$.

The objective of this study was to identify variables within an RD's personal beliefs about teaching fresh vegetable food safety, and their personal characteristics, that predict their teaching behavior related to teaching clients/patients about fresh vegetable food safety. 
We hypothesized that the willingness to teach, intend to teach, or to neither teach nor intend to teach about fresh vegetable food safety is a function of RD's personal beliefs regarding teaching fresh vegetable food safety, and/or their personal characteristics. The first hypothesis was that Perceived Behavioral Control (PBC), Attitude (Atd), and Subjective Norm (SN) would significantly predict the multinomial dependent variable (Behavior (B), Behavior Intention (BI), or Neither $(\mathrm{N}))$. The second hypothesis was that Perceived Behavioral Control (PBC) would be the better predictor of Behavior (B), as a binary dependent variable (currently teach or not).

By identifying and understanding dietitian's personal beliefs and characteristics that predict fresh vegetable food safety teaching behavior, food safety curriculum may be designed to impart more valuable and effective messages to RDs about the importance of understanding and teaching fresh vegetable food safety to all clients/patients. Perhaps this will lead to more RDs teaching their clients/patients about fresh vegetable food safety.

\subsection{Materials and Methods}

\subsubsection{Study Design and Subjects}

The study used a descriptive, cross-sectional survey design. A convenience sample of RDs was recruited from a conveniently selected group of nine American Dietetic Association (ADA) state affiliates from across the United States. To participate RDs had to be eighteen years of age or older, and were required to have current employment that involved direct client/patient education. Academic classroom education was not considered direct client/patient education and was 
considered exclusion criteria if that was the limit of the respondent's involvement in dietetic education. Filter questions were asked at the beginning of the survey to exclude any non-registered dietitians, anyone under the age of eighteen, and/or any RDs who did not directly consult with clients or patients as part of their job responsibilities. The survey, and all of the forms that were viewed by potential respondents, were approved by the Behavioral and Social Sciences Institutional Review Board for The Ohio State University (protocol \#2008B0345). An online waiver of informed consent was obtained from all respondents prior to beginning the survey.

\subsubsection{Survey design}

The survey was constructed according to guidelines proposed by the research of Griffin et al. $(12,13)$, and Aizen et al. $(9,10,11)$. The research of Griffin et al. utilized the Risk Information Seeking and Processing (RISP) model, which was derived from two separate models, one of which was the TPB $(9,10,11)$. Our survey included items that were based on the complete RISP model, but the current study presents results that probed only the belief variables of the TPB.

Measurement scales and scoring methods were modeled on those used by Griffin et al. and Aizen et al. (9). Items were measured using five-point Likert scales. Responses to the perceived behavioral control ("control belief") and subjective norm ("normative belief" and "motivation to comply") items were scored in a unipolar fashion and endpoints were 1 and 5, with 5 representing the most positive score, and 
1 representing the least positive score. The mid-point on the scale was representative of the neutral point.

Responses to the attitude ("behavioral belief" and "outcome evaluation") items were scored in a bipolar fashion so positive values were obtained for positive attitudes, and negative values for negative attitudes. Endpoints were 2 and -2 , with 2 representing the most positive score and -2 representing the most negative score. The 0 point on the scale was representative of the neutral point. Because of how the survey item that referred to "Having enough time to teach other things" was written, it was reverse coded so that a positive number would result from a positive attitude.

For this study the perceived behavioral control belief variable indicated the subjective degree of control each RD had over whether or not he/she taught fresh vegetable food safety to his/her clients/patients, currently or in the future. The attitude belief variable indicated the positive or negative attitude of each RD in regards to teaching fresh vegetable food safety. The subjective norm belief variable indicated whether the RD felt that their referent others, defined as clients/patients or other people who are personally important to them, would expect them to teach, or remain competent and current in, vegetable food safety information. Additionally, subjective norm indicated the RD's motivation to comply with the expectation of their referent others.

The dependent variable determined the participant's teaching behavior; "I currently teach my clients/patients about fresh vegetable food safety", or "even though I don't currently teach my clients/patients about fresh vegetable food safety I plan to in the future", or "I don't and never plan to teach my clients/patients about 
fresh vegetable food safety" (Appendix C, item 10). The multinomial dependent variable included each of the three options and was analyzed against a reference category, which in our case was "neither" for most of the analysis, and "currently teach" for the remainder of the analysis. The binary dependent variable included only those who reported they "currently teach", which was then analyzed against the sum of those who chose the alternative options; "I intend to teach" and "I do neither". After creating a draft of the survey instrument, a field test was completed by a convenience sample of five key informant RDs from the local metropolitan area. Each key informant was provided a hard copy of the survey to read and on which to write comments. Results from the field test were used to subjectively determine respondent burden and face validity. Behavioral belief questions initially developed by the research team about salient beliefs directly related to the behavior, teaching fresh vegetable food safety, were also reviewed and modified by the five key informant RDs. Efforts were made to incorporate a variety of items referring to different positive and negative salient beliefs regarding teaching fresh vegetable food safety. Key informants were asked to review the revised survey copy to give them the opportunity for final thoughts and suggestions.

Conversion of the revised survey to online format was followed by a pilot study, which was conducted with a convenience sample of sixteen RDs from the local metropolitan area. None of the dietitians had been involved in the field test. The pilot study was completed to beta test the website and to calculate psychometric properties of the survey items. Sample size statistics were completed using the data from the pilot study to determine the desired sample size of 300 RDs. 
Using pilot study data, contributions of survey items to the Cronbach alpha statistic were determined to measure internal consistency. The subjective norm and attitude items contributed to a set with a Cronbach alpha of .82 and .90 , respectively. Both of these were well above the .70 suggested as adequate (9). The perceived behavioral control items contributed to a set with a Cronbach alpha of .28, which may have been due to small sample size in the pilot. Because the researchers judged that the content of the perceived behavioral control items were potentially predictive to behavior, it was decided to retain all questions and recalculate internal consistency after additional data was collected in the final survey.

Personal characteristics were included in the survey and as control variables in the model throughout the analysis. Gender, age, household income, self-reported political philosophy, and specialty degrees were the personal characteristics included in the model. Both ethnicity and the state in which a majority of the RD's dietetic consulting took place were used as descriptive variables.

The final survey included 152 items, 39 of which related to the TPB and thus were used in the current study. To preserve the voluntary nature of the forced response style of a web-based survey, the option "I choose not to answer this question" was added to allow respondents to skip questions they did not want to answer. For analysis purposes this option was coded as "missing value". A working definition of "fresh vegetables", which specifically referred to tomatoes and green leafy vegetables, was presented on each page of the survey to preserve consistency of responses as related to the foods of food safety concern. 
Advertisements for the opportunity to complete the study, which included a link to the survey, were sent to listserves and posted on websites of American Dietetic Association state affiliates. Compensation, in the form of a 50-dollar gift card, was offered for those who completed the survey. Attempts were made to advertise consistently throughout the geographic regions of The United States, but not every state would allow advertisement to their members. Respondents came primarily from nine states, including California, Utah, Nevada, Colorado, Kansas, North Dakota, Ohio, Connecticut, and Maine, but additional states were also represented in the results.

\subsubsection{Internal Consistency Testing of the Belief Variables}

For the perceived behavioral control belief variable, "control belief” item scores were determined. Of the seven possible "control belief" items, only two contributed to a set with a Cronbach alpha value of .70 or above $(\alpha=0.91)$, when recalculated on the final study dataset (Table 3.1). The two items measured the RD's perceived quantity of knowledge about fresh vegetable food safety. The items asked whether or not they believed they had appropriate quantities of knowledge for their own purposes and for the purposes of teaching it to others. This was considered the respondent's perceived behavioral control over teaching fresh vegetable food safety. The scores for the two items were averaged to form the final perceived behavioral control belief variable score. 
Table 3.1. Items included in the perceived behavioral control variable.

\begin{tabular}{ll}
\hline I have a sufficient amount of knowledge & 5) Strongly agree \\
about fresh vegetable food safety for my & 4) Agree \\
personal use and safety. & 3) Not sure \\
& 2) Disagree \\
& 1) Strongly disagree \\
& 0) I choose not to answer this \\
& question
\end{tabular}

I have a sufficient amount of knowledge about the food safety of fresh vegetables to educate my clients/patients.

5) Strongly agree (Please answer this question even if you do not educate on fresh vegetable food safety)
4) Agree
3) Not sure
2) Disagree
1) Strongly disagree
0 ) I choose not to answer this question

For the attitude belief variable, each "behavioral belief" item was matched with a corresponding item that asked about the "outcome evaluation" of that belief. There were 20 belief/evaluation pairs that were used to construct the variable $(\alpha=0.70)$ (Appendix C, items 110-142). The products of these scores were averaged to form the full attitude belief variable score.

For the subjective norm belief variable, the scores from the two "normative belief" items were multiplied by the scores of the two "motivation to comply" items $(\alpha=0.82)$ (Table 3.2). The "normative belief" items measured whether the RDs felt that their referent others thought they should stay current on fresh vegetable food safety information, and whether they felt that their clients/patients thought they should teach the information. The "motivation to comply" items measured how motivated the RDs were to comply with their referent other's and clients/patients 
beliefs. The subjective norm belief variable was calculated by averaging the products of the "normative belief" scores and the "motivation to comply" scores.

Table 3.2. The four subjective norm items from the survey.

Normative Belief Items

People who are important to me would expect me to stay on top of information

5) Strongly agree about the food safety of fresh vegetables.

4) Agree

3) Neutral

2) Disagree

1) Strongly disagree

0 ) I choose not to answer this question

My clients/patients expect me to teach them about the food safety of fresh

5) Strongly agree vegetables.

4) Agree

3) Neutral

2) Disagree

1) Strongly disagree

0) I choose not to answer this question

Motivation to Comply Items

Generally speaking I want to do what my clients/patients think I should do.

5) Strongly agree

4) Agree

3) Neutral

2) Disagree

1) Strongly disagree

0) I choose not to answer this question

Generally speaking I want to do what people who are important to me think I should do.

5) Strongly agree

4) Agree

3) Neutral

2) Disagree

1) Strongly disagree

0 ) I choose not to answer this question 


\subsubsection{Spearman Correlation Analysis}

A subset of belief/evaluation pairs was selected from the 20 acceptable belief/evaluation pairs that were used to create the full attitude belief variable. This subset was used to create the "best-fit predictive model". Spearman correlations were used to determine the pairs with the best association with the multinomial dependent variable. Seven of the belief/evaluation pairs were significantly and positively correlated with the multinomial dependent variable (Table 3.3).

Table 3.3. Attitudes $\mathrm{a}$ used in the "best-fit predictive model"

\begin{tabular}{|c|c|c|c|}
\hline Attitude & & Survey Items & $\begin{array}{l}\text { Spearman } \\
\text { Correlation }\end{array}$ \\
\hline \multirow[t]{2}{*}{$\begin{array}{l}\text { Less foodborne illness } \\
\text { among clients/patients. }\end{array}$} & $\begin{array}{l}\text { Behavioral } \\
\text { Belief }\end{array}$ & $\begin{array}{l}\text { Teaching fresh } \\
\text { vegetable food safety } \\
\text { means decreased illness } \\
\text { among clients/patients. }\end{array}$ & $r=0.12$ \\
\hline & $\begin{array}{l}\text { Outcome } \\
\text { Evaluation }\end{array}$ & $\begin{array}{l}\text { In your own opinion, } \\
\text { how important is less } \\
\text { foodborne illness } \\
\text { among your } \\
\text { clients/patients? }\end{array}$ & \\
\hline \multirow[t]{2}{*}{$\begin{array}{l}\text { Having enough time to } \\
\text { teach other things. }\end{array}$} & $\begin{array}{l}\text { Behavioral } \\
\text { Belief }\end{array}$ & $\begin{array}{l}\text { Teaching fresh } \\
\text { vegetable food safety } \\
\text { causes me to have less } \\
\text { time to teach other } \\
\text { important nutrition } \\
\text { concepts. }\end{array}$ & $\mathrm{r}=0.24^{* * *}$ \\
\hline & $\begin{array}{l}\text { Outcome } \\
\text { Evaluation }\end{array}$ & $\begin{array}{l}\text { In your own opinion, } \\
\text { how important is } \\
\text { having enough time to } \\
\text { teach other important } \\
\text { concepts? }\end{array}$ & \\
\hline
\end{tabular}


Table 3.3 continued

\begin{tabular}{|c|c|c|c|}
\hline \multirow[t]{2}{*}{$\begin{array}{l}\text { Having thankful } \\
\text { clients/patients. }\end{array}$} & $\begin{array}{l}\text { Behavioral } \\
\text { Belief }\end{array}$ & $\begin{array}{l}\text { Will teaching fresh } \\
\text { vegetable food safety } \\
\text { cause you to have } \\
\text { thankful } \\
\text { clients/patients? }\end{array}$ & $r=0.14^{* * *}$ \\
\hline & $\begin{array}{l}\text { Outcome } \\
\text { Evaluation }\end{array}$ & $\begin{array}{l}\text { In your own opinion, } \\
\text { how important is } \\
\text { having thankful } \\
\text { clients/patients? }\end{array}$ & \\
\hline \multirow[t]{2}{*}{$\begin{array}{l}\text { Having clients/patients } \\
\text { who listen to the } \\
\text { information you teach. }\end{array}$} & $\begin{array}{l}\text { Behavioral } \\
\text { belief }\end{array}$ & $\begin{array}{l}\text { Teaching fresh } \\
\text { vegetable food safety } \\
\text { will cause my } \\
\text { clients/patients to not } \\
\text { listen to me. }\end{array}$ & $\mathrm{r}=0.17^{* *}$ \\
\hline & $\begin{array}{l}\text { Outcome } \\
\text { Evaluation }\end{array}$ & $\begin{array}{l}\text { In your own opinion, } \\
\text { how important is } \\
\text { having clients/patients } \\
\text { who listen to you? }\end{array}$ & \\
\hline \multirow[t]{2}{*}{$\begin{array}{l}\text { Organic vegetables } \\
\text { have superior taste. }\end{array}$} & $\begin{array}{l}\text { Behavioral } \\
\text { Belief }\end{array}$ & $\begin{array}{l}\text { Teaching fresh } \\
\text { vegetable food safety } \\
\text { will cause my } \\
\text { clients/patients to } \\
\text { purchase only organic } \\
\text { fresh vegetables. }\end{array}$ & $\mathrm{r}=0.14^{*}$ \\
\hline & $\begin{array}{l}\text { Outcome } \\
\text { Evaluation }\end{array}$ & $\begin{array}{l}\text { In your own opinion, } \\
\text { how important are is it } \\
\text { to choose organic fresh } \\
\text { vegetables for their } \\
\text { superior taste? }\end{array}$ & \\
\hline $\begin{array}{l}\text { Organic vegetables are } \\
\text { superior in nutritional } \\
\text { quality. }\end{array}$ & $\begin{array}{l}\text { Behavioral } \\
\text { Belief }\end{array}$ & $\begin{array}{l}\text { Teaching fresh } \\
\text { vegetable food safety } \\
\text { will cause my } \\
\text { clients/patients to } \\
\text { purchase only organic } \\
\text { fresh vegetables. }\end{array}$ & $\mathrm{r}=0.13^{*}$ \\
\hline
\end{tabular}


Table 3.3 Continued

\begin{tabular}{|c|c|c|c|}
\hline \multirow{3}{*}{$\begin{array}{l}\text { Organic vegetables are } \\
\text { less likely to be } \\
\text { contaminated with } \\
\text { pesticides and } \\
\text { herbicides. }\end{array}$} & $\begin{array}{l}\text { Outcome } \\
\text { Evaluation }\end{array}$ & $\begin{array}{l}\text { In your own opinion, } \\
\text { how important is it to } \\
\text { choose organic fresh } \\
\text { vegetables for their } \\
\text { superior nutritional } \\
\text { quality? }\end{array}$ & \multirow{3}{*}{$\mathrm{r}=0.13^{*}$} \\
\hline & $\begin{array}{l}\text { Behavioral } \\
\text { Belief }\end{array}$ & $\begin{array}{l}\text { Teaching fresh } \\
\text { vegetable food safety } \\
\text { will cause my } \\
\text { clients/patients to } \\
\text { purchase only organic } \\
\text { fresh vegetables. }\end{array}$ & \\
\hline & $\begin{array}{l}\text { Outcome } \\
\text { Evaluation }\end{array}$ & $\begin{array}{l}\text { In your own opinion, } \\
\text { how important is it to } \\
\text { choose organic fresh } \\
\text { vegetables because they } \\
\text { are less likely to be } \\
\text { contaminated with } \\
\text { pesticides and } \\
\text { herbicides? }\end{array}$ & \\
\hline \multicolumn{4}{|l|}{ a. $\quad$ Attitude = belief/evaluation pair } \\
\hline $\begin{array}{l}* \mathrm{p} \leq 0.05 \\
* * \mathrm{p} \leq 0.01 \\
* * * \mathrm{p} \leq 0.001\end{array}$ & & & \\
\hline
\end{tabular}

\subsubsection{Statistical Analysis}

Data analysis was completed using the statistical program, Statistical Program for the Social Sciences (SPSS, version 17.0, Chicago, IL). Means and percentages were calculated to describe demographic variables. Spearman correlation analysis was completed for the belief variables and personal characteristics against the binary and multinomial dependent variables. Multinomial logistic regression analysis was used to test model fitness and for determining the effects of the belief variables. Data were analyzed using the "full model", which included all 20 belief/ evaluation pairs, 
and the "best-fit predictive model", which included only the seven belief/evaluation pairs shown in Table 3.3. Binary logistic regression analysis was used to test if the PBC belief variable predicted actual teaching behavior (currently teaching or not) better than both attitude and subjective norm. Statistical significance was declared of $\mathrm{p} \leq 0.05$.

\subsection{Results}

\subsubsection{Respondent Demographics}

Data was collected from 347 RDs through a web interface and imported into a database located on a secure server. Twenty of the respondents did not finish the survey and therefore were not included in the analysis. The final sample size was 327.

The personal characteristics of respondents are reported in Table 3.4. Study respondents were predominantly white/non-Hispanic (91.0\%) and female (96.9\%). The American Dietetic Association's latest membership demographic data indicated $86.55 \%$ of members are white and $3.0 \%$ are males (49), which is a near description of the survey sample. The majority of respondents were between the ages of 30 and 44 (36.4\%). Of all the respondents, 56.7\% had postgraduate education. Respondents were generally located throughout the United States (Figure 3.1): Western (27.8\%), Midwestern (20.2\%), Southern (20.8\%), and Northeastern (31.2\%). States included in these regions are consistent with the definitions of the US Census Bureau (36). 


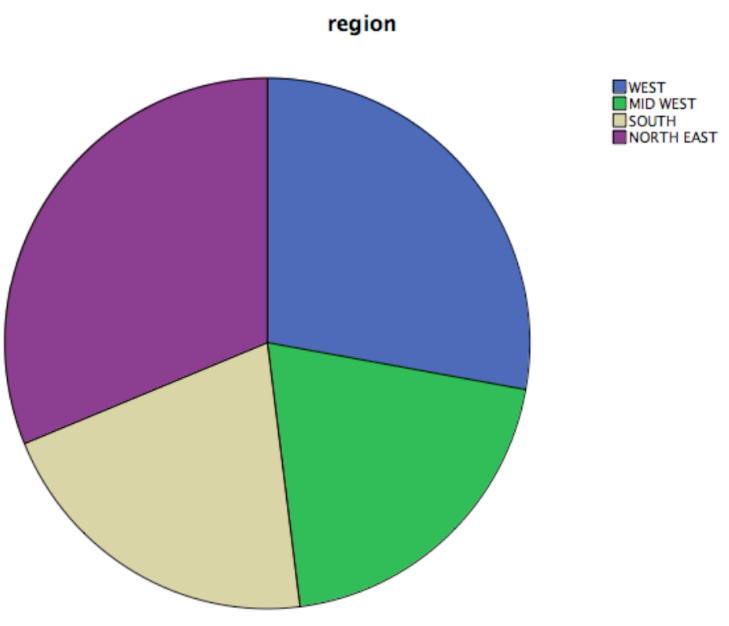

Figure 3.1. Regional dispersion of survey respondents. 
Table 3.4. Personal characteristics of the survey respondents.

Characteristic

Frequency (n)

Percentage (\%)

Gender

Male

Female

Age (years)

$18-29$

30-44

45-59

$60-74$

Education

College graduate

Postgraduate

Total Family Income

$\$<35,000$

$\$ 45,000-54,000$

$\$ 55,000-64,000$

$\$ 65,000-74,000$

$\$ 75,000-84,000$

$\$ 85,000-99,000$

$\$ 100,000$ and up

Self- Reported

Political Philosophy

Very liberal

Liberal

Neutral

Conservative

Very conservative
9

317

2.8

97.2

26.6

36.4

32.7

107

4.3

14

87

119

14

.

142

184

43.6

56.4
16

44

31

28

31

43

93
5.6

15.4

10.8

9.8

10.8

15.0

32.5 
Out of the 327 respondents, 168 said they "currently teach fresh vegetable food safety", 134 said they "intend to teach fresh vegetable food safety", and 25 said they "neither intend to teach nor currently teach fresh vegetable food safety".

\subsubsection{Means and Correlations}

The mean attitude score was 0.4 , which indicated a near neutral attitude. The mean subjective norm score was 14.3, which indicated a positive influence of clients/patients and others important to the respondents regarding whether they should teach fresh vegetable food safety, or stay current on fresh vegetable food safety information. The mean perceived behavioral control score was 4.4, which indicated a high degree of perceived fresh vegetable food safety knowledge.

Perceived behavioral control, attitude, and subjective norm were significantly $(p \leq 0.001)$ and positively correlated with the multinomial dependent variable (Table 3.5). $\mathrm{SN}(\mathrm{r}=0.20, \mathrm{p} \leq 0.001), \mathrm{PBC}(\mathrm{r}=0.29, \mathrm{p} \leq 0.001)$, and attitude $(\mathrm{r}=0.20, \mathrm{p} \leq 0.001)$ were also positively correlated with the binary dependent variable. The age of the RD was the only demographic variable that correlated with the multinomial dependent variable $(\mathrm{r}=0.26, \mathrm{p} \leq .0001)$ (data not shown). Age also correlated with the binary dependent variable (currently teach, or not) $(r=0.27, \mathrm{p} \leq 0.001)$ (data not shown). 
Table 3.5. Spearman correlations for the independent belief variables.

\begin{tabular}{cccccc}
\hline & $\begin{array}{c}\text { Teaching } \\
\text { Behavior } \\
\text { (Multinomial } \\
\text { Dependent) }\end{array}$ & $\begin{array}{c}\text { Teaching } \\
\text { Behavior } \\
\text { (Binary } \\
\text { Dependent) }\end{array}$ & $\mathrm{PBC}^{\mathrm{a}}$ & $\mathrm{ATD}^{\mathrm{b}}$ & $\mathrm{SN}^{\mathrm{c}}$ \\
\hline $\begin{array}{c}\text { Teaching } \\
\text { Behavior } \\
\text { (Multinomial } \\
\text { Dependent) }\end{array}$ & 1 & & & & \\
$\begin{array}{c}\text { Teaching } \\
\text { Behavior } \\
\text { (Binary }\end{array}$ & $0.97^{*}$ & 1 & & & \\
$\begin{array}{c}\text { Dependent) } \\
\text { PBC }\end{array}$ & $0.24^{\mathrm{a}}$ & $0.20^{*}$ & 1 & & \\
Atd $^{\mathrm{b}}$ & $0.23^{*}$ & $0.20^{*}$ & $0.35^{*}$ & 1 & \\
$\mathrm{SN}^{\mathrm{c}}$ & $0.28^{*}$ & $0.29^{*}$ & 0.08 & 0.09 & \\
\hline $\begin{array}{l}\text { a. Perceived Behavioral Control } \\
\text { b. Attitude } \\
\text { c. Subjective Norm }\end{array}$ & & & & \\
\hline * $\mathrm{p}=\leq .001$ & & & & \\
\hline
\end{tabular}

\subsubsection{Multinomial Logistic Regression Analysis}

Multinomial logistic regression analysis was used to regress the belief variables of the "full model" with the multinomial dependent variable $\left(\mathrm{R}^{2}=0.19, \mathrm{p} \leq\right.$ 0.001). After controlling for personal characteristics, the model was significant in predicting $30 \%\left(\mathrm{R}^{2}=0.30, \mathrm{p} \leq 0.001\right)$ of the variation in the multinomial dependent variable. The full attitude belief variable had the greatest effect on whether the RD currently taught fresh vegetable food safety $(\beta=1.72, \mathrm{p}=0.008)$, followed by PBC $(\beta=1.02, p=0.044)$, the age of the $\operatorname{RDs}(\beta=0.85, p=0.032)$, and $\mathrm{SN}(\beta=0.24, \mathrm{p} \leq$ 
0.001). The only belief variable that had a significant effect on whether the RD intended to teach fresh vegetable food safety was subjective norm $(\beta=0.21, p=0.004)$. The two variables that significantly effected whether the $\mathrm{RD}$ intended to teach, compared to currently teaching were PBC ( $\beta=-1.3, p \leq 0.001)$, and the age of the RDs $(\beta=-0.81, \mathrm{p} \leq 0.001)$.

Table 3.6 shows the "best-fit predictive model" for predicting the multinomial dependent variable. The model accounted for $35 \%$ of the variance in the multinomial dependent variable $\left(\mathrm{R}^{2}=0.35, \mathrm{p} \leq 0.001\right)$. Intention to teach fresh vegetable food safety was most effected by the belief/evaluation pair "Organic vegetables are superior in nutritional quality" $(\beta=0.78 \mathrm{p}=0.04)$. Perceived behavioral control had the greatest effect on whether the RD currently taught fresh vegetable food safety $(\beta=1.309, p=0.018)$. The belief/evaluation pair "Having enough time to teach other things" had the second greatest effect on whether the RD currently taught fresh vegetable food safety $(\beta=0.48, p=0.014)$, followed by subjective norm $(\beta=0.21$, $\mathrm{p}=0.012)$

Five variables significantly affected whether the RD intended to teach, compared to currently teaching (Table 3.6). Perceived behavioral control had the greatest effect $(\beta=-1.33, \mathrm{p} \leq 0.001)$, followed by the age of the $\mathrm{RD}(\beta=-0.81, \mathrm{p} \leq$ 0.001), the RD's education ( $\beta=0.74, p=0.026$ ), and the belief/ evaluation pairs "Organic vegetables are less likely to be contaminated with pesticides and herbicides" $(\beta=-0.36, p=0.015)$, and "Having enough time to teach other things" $(\beta=-.31, \mathrm{p}=$ $0.003)$. 
Table 3.6. Multinomial logistic regression analysis for the "best-fit predictive model"a

\begin{tabular}{|c|c|c|c|}
\hline $\begin{array}{l}\text { Multinomial } \\
\text { Dependent } \\
\text { Variable }^{b}\end{array}$ & $\begin{array}{l}\text { Independent } \\
\text { Belief } \\
\text { Variable }\end{array}$ & $\begin{array}{c}\text { Beta } \\
\text { Coefficient }\end{array}$ & $\begin{array}{c}\text { Beta } \\
\text { P-value }\end{array}$ \\
\hline Intention/Neither & Atd $1^{\mathrm{c}}$ & 0.78 & 0.038 \\
\hline \multirow[t]{3}{*}{ Current/Neither } & $\mathrm{PBC}^{\mathrm{d}}$ & 1.31 & 0.018 \\
\hline & $\operatorname{Atd} 2^{\mathrm{e}}$ & 0.48 & 0.014 \\
\hline & $\mathrm{SN}^{\mathrm{f}}$ & 0.21 & 0.012 \\
\hline \multirow[t]{5}{*}{ Intention/Current } & $\mathrm{PBC}^{\mathrm{d}}$ & -1.33 & 0.001 \\
\hline & Age $(\text { years })^{g}$ & -0.81 & 0.001 \\
\hline & Education $^{\mathrm{h}}$ & 0.74 & 0.026 \\
\hline & $\operatorname{Atd} 3^{i}$ & -0.36 & 0.015 \\
\hline & $\operatorname{Atd} 2^{\mathrm{e}}$ & -0.31 & 0.003 \\
\hline \multicolumn{4}{|l|}{ a. $\mathrm{R}$-squared $=.35, \mathrm{p} \leq .001$} \\
\hline \multicolumn{4}{|c|}{ b. The reference category for the multinomial dependent was either "neither" or "currently teach" } \\
\hline \multicolumn{4}{|c|}{ c. Atd $1=$ belief/evaluation pair; "Organic vegetables are superior in nutritional quality". } \\
\hline \multicolumn{4}{|c|}{ d. Perceived Behavioral Control } \\
\hline \multicolumn{4}{|c|}{ e. Atd2=belief/evaluation pair; "Having enough time to teach other things" } \\
\hline \multicolumn{4}{|l|}{ f. Subjective Norm } \\
\hline \multicolumn{4}{|c|}{ g. The older age of the RD negatively effects intending to teach, compared to currently teaching } \\
\hline \multicolumn{4}{|c|}{ h. Having a post college graduate degrees positively effects intending to teach, compared to currently teaching } \\
\hline
\end{tabular}




\subsubsection{Binary Logistic Regression Analysis}

Binary logistic regression analysis was completed to test the hypothesis that perceived behavioral control would be the better single predictor of whether the RD currently taught (Table 3.7). Consistent with the hypothesis, perceived behavioral control explained the most variability in the binary dependent variable, whether the $R D$ currently taught fresh vegetable food safety $\left(R^{2}=0.19, p \leq 0.001\right)$. Subjective norm was the second best predictor of whether the RD currently taught fresh vegetable food safety $\left(\mathrm{R}^{2}=0.13, \mathrm{p}=0.004\right)$, followed by the full attitude belief variable $\left(\mathrm{R}^{2}=0.13, \mathrm{p} \leq 0.001\right)$.

The seven belief/evaluation pairs that were used for the "best-fit predictive model" (Table 3.7) were entered together into a separate binary logistic regression analysis, in addition to the personal characteristics, and accounted for $18.0 \%$ of the variance in actual behavior $\left(\mathrm{R}^{2}=0.18, \mathrm{p} \leq 0.001\right)$. However, only two of them significantly and positively effected whether the RD currently taught: "Having enough time to teach other things" ( $\beta=0.38, \mathrm{p} \leq 0.001)$, and "Organic vegetables are less likely to be contaminated with pesticides and herbicides" $(\beta=0.27, \mathrm{p}=0.046)$. 
Table 3.7. Binary logistic regression analysis for each individually analyzed belief variables ${ }^{\mathrm{a}}$.

\begin{tabular}{|c|c|c|c|}
\hline $\begin{array}{l}\text { Independent } \\
\text { Variable }\end{array}$ & $\mathrm{R}^{2}$ & Beta & $\begin{array}{c}\text { Beta } \\
\text { P-value }\end{array}$ \\
\hline $\mathrm{PBC}^{\mathrm{b}}$ & 0.19 & 1.28 & $\leq 0.001$ \\
\hline $\mathrm{SN}^{\mathrm{c}}$ & 0.13 & 0.09 & 0.004 \\
\hline Atd $1^{\mathrm{d}}$ & 0.13 & -0.84 & 0.006 \\
\hline $\operatorname{Atd} 2^{\mathrm{e}}$ & 0.18 & 0.38 & $\leq 0.001$ \\
\hline $\operatorname{Atd} 3^{\mathrm{f}}$ & 0.18 & 0.27 & 0.046 \\
\hline \multicolumn{4}{|c|}{ a. All R-squared values were significant at the $p \leq 0.001$ level } \\
\hline \multicolumn{4}{|c|}{ b. Perceived Behavioral Control } \\
\hline \multicolumn{4}{|l|}{ c. Subjective Norm } \\
\hline \multicolumn{4}{|c|}{ d. Atd $1=$ Full attitude belief variable, including all 20 belief/ evaluation pairs. } \\
\hline \multicolumn{4}{|c|}{ e. Atd $2=$ Belief//valuation pair; "Having enough time to teach other things" } \\
\hline f. Atd $3=$ Belief/eval & vegetabl & a & \\
\hline
\end{tabular}

\subsection{Discussion}

In this study the Theory of Planned Behavior was applied to RDs teaching fresh vegetable food safety to their clients/patients, in order to identify RD's personal beliefs about teaching fresh vegetable food safety, and their personal characteristics that predict fresh vegetable food safety teaching behavior. We hypothesized that the belief variables of the TPB would significantly predict the RD's fresh vegetable food safety teaching behavior and that perceived behavioral control (PBC) would be the better predictor of whether the RD currently taught fresh vegetable food safety to their clients/patients. Each of our hypotheses was supported by the statistical analysis. The "best-fit predictive model" explained $35.0 \%(\mathrm{p} \leq 0.001)$ of the variance 
in teaching behavior, and $\mathrm{PBC}$ was the better predictor of whether the RDs currently taught $\left(\mathrm{R}^{2}=0.19, \mathrm{p} \leq 0.001\right)$. Each of the three belief variables, in addition to three specific attitude belief/evaluation pairs, and the education status and age of the RD, had significant effects on whether the RD currently taught fresh vegetable food safety. Outcomes from the current study were similar to a study, which found that the independent belief variables of the TPB explained $27.8 \%$ of the variance in RD's intentions to teach about whole grains (32).

Both of the perceived behavioral control survey items were related to the RD's perceived quantity of knowledge about fresh vegetable food safety. The items referred to whether they perceived they had enough knowledge for their own use or for teaching purposes. According to Icek Aizen, if performance of a behavior requires skills that are currently lacking, the person also has less personal control over the behavior $(9,10,11)$. Perceived behavioral control significantly and positively affected whether the RD currently taught $(\beta=1.309, \mathrm{p}=0.018)$. Perceived behavioral control also had significant and negative effects on whether the RD intended to teach, compared to currently teaching. As hypothesized, $\mathrm{PBC}$ was the better single predictor of whether the RD currently taught $\left(\mathrm{R}^{2}=0.19, \mathrm{p} \leq 0.001\right)$.

Results of a study not yet published (personal communication, Lydia Medeiros), which looked at RD's perceived quantity of fresh vegetable food safety knowledge, indicated there was a significant difference in the perceived quantity of knowledge among the RDs who currently taught fresh vegetable food safety compared to those who intended to teach or who did neither $(p<0.00)$. These same respondents answered specific fresh vegetable food safety questions and scores were 
not statistically different $(p=0.07)$. From these results it can be implied that even if an RD has accurate knowledge about fresh vegetable food safety, they may not teach it unless they are confident with their knowledge. These results, coupled with the results of the current study, suggest that perceptions of appropriate quantities of knowledge among RDs is a powerful predictor of, and has a positive influence on teaching fresh vegetable food safety to clients/patients.

The full attitude belief variable had a significant positive effect on whether the RD currently taught fresh vegetable food safety $(\beta=1.72, p=0.008)$. In addition, the full attitude belief variable significantly predicted the binary dependent variable (currently teach or not) $\left(\mathrm{R}^{2}=0.13, \mathrm{p} \leq 0.001\right)$, but the effect was significantly negative $(\beta=-0.84, p=0.006)$, which was an unexpected finding.

The RDs who were surveyed in a similar study dealing with intentions to teach whole grains (32) indicated positive attitudes about the benefits of whole grains, but their attitudes were not as effective as $\mathrm{PBC}$ and SN in predicting intentions to teach whole grains. Another study, which used the TPB and TRA to predict physician intentions and behavior, found that attitudes yielded a significant positive effect on physician's intentions to conduct STD-HIV education $(\beta=0.22, \mathrm{p} \leq 0.001)$, but not behavior (29).

Multinomial and binary logistic regression analyses' were completed using just the seven belief/evaluation pairs, in what was referred to as the "best-fit predictive model". When binary logistic regression analysis was completed with only the seven belief/evaluation pairs, and the personal characteristics, they explained a significant amount of variance in whether the $\mathrm{RD}$ currently taught $\left(\mathrm{R}^{2}=\right.$ 
$0.18, \mathrm{p} \leq 0.001$ ). The attitude (belief/evaluation pair) regarding teaching fresh vegetable food safety and having enough time to teach other things had the most significant effect on whether the RD currently taught fresh vegetable food safety $(\beta=$ $0.479, \mathrm{p}=0.014)$. In addition the "best-fit predictive model" significantly predicted the binary dependent variable (currently teach nor not) $(\beta=0.38, p \leq 0.001)$. Results from another similar study found that $6 \%$ of the RDs who were surveyed perceived "too little time" as being a barrier to teaching about whole grains (32).

Included in our survey was an item that asked respondents who claimed to not currently teach fresh vegetable food safety, why they did not currently teach (see appendix $\mathrm{C}$, item 12). This item was not included in the regression analysis, however a frequency analysis was completed for purposes of this discussion. Twenty-three percent of the RDs who did not currently teach said that not having enough time was the main reason they did not teach. These results indicate the need for RDs to make more efficient use of client/patient education time if food safety information is to be provided. Educators of food safety who teach RDs might want to teach some simple strategies for including fresh vegetable food safety information into an education session. Advice such as the importance of rinsing fresh vegetables, drying off produce before storing it in the refrigerator, and cutting off any brown spots, could each be effective at preventing pathogen growth or contamination and should not take excessive time (4).

The attitude (belief/evaluation pair) regarding teaching fresh vegetable food safety and its relation to clients/patients choosing only organic vegetables for their superior nutritional qualities, had the greatest effect on whether the RD intended to 
teach fresh vegetable food safety $(\beta=0.80 \mathrm{p}=0.040)$. The attitude (belief/evaluation pair) regarding teaching fresh vegetable food safety and its relation to clients/patients choosing only organic fresh vegetables for their least likelihood of being contaminated with pesticides and herbicides, had a significant and negative effect on whether the $\mathrm{RD}$ intended to teach, compared to currently teaching $(\beta=-0.36$, $\mathrm{p}=0.015$ ), and it also had a significant and positive effect on whether the RD currently taught fresh vegetable food safety $(\beta=0.27, p=0.046)$.

Organic produce is becoming more important to consumers and RDs (37). Results from this study, and a thorough review of information regarding organic produce, indicates that food safety may be perceived as a broader meaning, which does not focus on pathogens and their associated risks. Specifically, organic foods are looked at as safer for the environment, farm workers, and vulnerable populations, in terms of their decreased amounts of pesticide residues, hormone residues, and potentially harmful nitrates (38). The 1996 passage of the Food Quality and Protection Act (39) highlighted the importance of the heightened susceptibility of infants and children, the elderly, and immune-compromised to the negative consequences of pesticides. Additional information has been published regarding organic produces' increased amounts of omega-3 fatty acids, vitamin C, iron, magnesium, phosphorus, and antioxidants, another benefit for long-term health (40). Fresh vegetable food safety educators should teach RDs about organic produce and its relation to food safety. Specifically it should be noted that organic produce is no more or less likely to be contaminated with pathogens, and purchasing organic produce can be beneficial for both short term and long-term health (38). 
In the current study subjective norm was assessed to determine if the RDs were socially influenced to teach by clients/patients and important others. Subjective norm had a significant and positive effect on whether the RD currently taught fresh vegetable food safety $(\beta=0.21, \mathrm{p}=0.012)$. When analyzed alone, along with the personal characteristics, subjective norm was the second best predictor of the binary dependent variable (currently teach or not) $\left(R^{2}=0.13, p \leq 0.001\right)$. Similar results were found in a study that used the TPB to predict RD's intentions to teach about whole grains (32), which found that subjective norm was the better predictor of behavioral intentions. Results from a study that examined physician's behavior with regard to teaching STD-HIV education found that subjective norm significantly affected physician's intentions, or actions toward teaching (29).

Study outcomes support the idea that educators should consider highlighting the socially normative nature $\mathrm{RDs}$ associate with teaching certain topics to clients/patients, such as fresh vegetable food safety, in the education curriculum. Young adults and employers are showing more interest in general food safety information (41), so discussing fresh vegetable food safety is likely to be valued by clients/patients and referent others.

Age was a personal characteristic that significantly effected behavior. The older age of the dietitian had a significant and positive effect on whether they currently taught $(\beta=0.85, p=0.032)$. The older age of the $R D$ had a significant and negative effect on whether they intended to teach, compared to currently teaching ( $\beta=-0.81, p \leq 0.001)$. This indicates there may be less focus on fresh vegetable food safety in the current dietetic education curricula. 
Currently about fifty percent of RDs have some type of graduate degree (54). Education was another personal characteristic that significantly affected behavior. Specifically, having any type of postgraduate degree significantly and negatively affected whether the RD currently taught fresh vegetable food safety. Postgraduate degrees significantly and negatively affected whether the RD currently taught, compared to intending to teach $(\beta=-0.74, \mathrm{p}=0.026)$. This indicates that greater levels of education does not necessarily mean RDs will be more likely to teach fresh vegetable food safety to their clients/patients.

In summary, this study identified the personal beliefs and characteristics of RDs that significantly predicted their fresh vegetable food safety teaching behavior. Each of the belief variables of the TPB contributed to a significant amount of variance explained, and perceived behavioral control was the better single predictor of whether the RD currently taught. Fresh vegetable food safety education for RDs should include the following; ways to increase perceived knowledge and confidence about teaching fresh vegetable food safety, client's/patient's and referent other's opinions on the importance of RDs teaching fresh vegetable food safety, information on organic produce and its connection to short-term and long-term health benefits, as well as some simple strategies on teaching fresh vegetable food safety information in a more time effective manor. The finding that increased age had a positive effect on whether an RD teaches fresh vegetable food safety information may be indicative of an undergraduate dietetic education system that is slowly focusing less on food safety. Lastly, it should not be assumed that an RD with an advanced degree is any more likely to teach fresh vegetable food safety. These results can be helpful in 
creating more effective continuing education curriculum, seminars, conferences, and/or any other type of fresh vegetable food safety education directed at RDs.

\subsection{Bibliography}

1. Center for Disease Control. Family reunion health and safety tips. The Center For Disease Control Web site. www.cdc.gov/family/reunions/. Accessed November 4, 2008.

3. Palumbo M, Gorny J, Gombas D. Recommendations for handling fresh-cut leafy green salads by consumers and retail foodservice operators. Food Protection Trends. 2007;27(11):892-898.

6. Palmer S. The E.coli outbreak; Lettuce learn a lesson. Today's Dietitian. 2007;9(1):28-4.2.

7. American Dietetic Association, Commission on Accreditation for Dietetics Education. Dietetics Education Curriculum Requirements - 2008 Accreditation Standards. The American Dietetic Association Web site. http://www.eatright.org/cps/rde/xchg/ada/hs.xsl/CADE 813 ENU HTML.htm. Accessed November 9, 2008.

8. Griffin RJ, Dunwoody S, Neuwirth K, Giese J. Linking the heuristic-systematic model and depth of processing. Communication Research. 2002;29(6):705-732.

9. Ajzen I. The theory of planned behavior. Organ Behav Hum Decis Process. 1991;50:179-211.

10. Ajzen I. Attitudes, Personality, and Behavior. United Kingdom: Open University Press; 1988.

11. Fishbein M, Ajzen I. Belief, Attitude, Intentions, and Behavior: An Introduction to Theory and Research. Reading, MA: Addison-Wesley; 1975.

12. Griffin R, Dunwoody S, Neuwirth K. Proposed model of the relationship of risk information seeking and processing to the development of preventive behaviors. Environmental Research. 1999;Section A80:S230-S245.

13. Griffin R, Neuwirth K, Dunwoody S, Giese J. Information sufficiency and risk communication. Media Psychology. 2004;6:23-61. 
20. American Dietetic Association Accreditation and Education Programs. For registered dietitian, a food and nutrition expert, educational and professional requirements. The American Dietetic Association Web site. http://www.eatright.org/cps/rde/xchg/ada/hs.xsl/CADE_748_ENU_HTML.htm. Accessed March 2009.

21. Sneed J, Strohbehn C. Trends impacting food safety in retail foodservice: Implications for dietetics practice. J Am Diet Assoc. 2008;108(7):1170-1177.

22. Commission on Dietetic Registration. About CDR. American Dietetic Association Web site. http://cdrnet.org/about/index.htm. Accessed July 12, 2009.

29. Millstein S. Utilities of the theories of reasoned action and planned behavior for predicting physician's behavior: A prospective study. Health Psychology. 1996;15(5):398-402.

32. Chase K, Reicks M, Jones J. Applying the theory of planned behavior to promotion of whole-grain foods by dietitians. J Am Diet Assoc. 2003;103(12):16391642.

35. Salomon S. Diversifying dietetics; A challenge that's well worth the effort. Today's Dietitian. 2009;11(13):26-30.

36. United States Census Bureau. Census regions and divisions of the United States. The United States Census Bureau Web site. www.census.gov/geo/www/us_regdiv.pdf. Accessed May 2009.

37. Hasenecz N. Consumers drive back-to-basics food trend. Today's Dietitian. 2009;11(9):38-41. http://www.epa.gov/opp00001/regulating/laws/fqpa/backgrnd.htm. Accessed June, 2009.

38. Hemmelgarn M. Bacteria and beyond; Getting to the root of food safety issues. Today's Dietitian. 2009;11(6):56-57.

39. United States Environmental Protection Agency. The food quality protection act (FQPA) background. United States Environmental Protection Agency Web site.

40. Worthington V. Nutritional quality of organic versus conventional fruits, vegetables, and grains. J Altern Complement Med. 2001:161-173.

42. Grieger L. To degree or not to degree? Today's Dietitian. 2005;7(7):31-33. 


\section{EPILOGUE}

\subsection{Study Conclusions and Major Findings}

The results of this study show that RD's perceptions of knowledge regarding fresh vegetable food safety, the influence of clients/patients and other important persons, and specific attitudes about teaching fresh vegetable food safety are predictive of RDs teaching behavior. The study provides good information on which dietetic educators could base curriculum for dietetic education and for continuing education. Because RDs are more likely to teach fresh vegetable food safety if they perceive they have the appropriate quantity of knowledge, there is an incentive to continue educating RDs on fresh vegetable food safety as they progress throughout their career.

\subsection{Limitations of the Study}

A limitation of the study was the lack of any other TPB study that had used the adapted version of the TPB. Our research was a cross-sectional, descriptive study, that assessed teaching behavior by asking whether respondents currently taught, intended to teach, or did neither. Most studies have asked respondents to 
indicate both, whether they currently teach, and whether they intend to teach. By designing a survey in this way the three belief variables can be regressed against behavioral intention, and behavioral intention can be regressed against behavior. Hierarchial regression analysis can then be used to determine whether $\mathrm{PBC}$ has a direct effect on behavior, independent from behavioral intention and the other two belief variables, as is suggested by the non-adapted TPB model.

Another limitation was the inability to survey every RD in the United States. Clearly this would have been a near impossible task, but even so, it limited the ability for the results to apply to every RD. Thankfully our 327 respondents represented well the United States' population of RDs.

The final limitation was the length of the survey. There were only fifty-nine TPB questions. The small amount of questions only allowed for us to analyze certain salient beliefs, when in reality there are many more salient beliefs about teaching fresh vegetable food safety that could have been analyzed. Knowing very well that most people do not want to participate in a survey that will take much longer than an hour, we were limited to a smaller amount of questions.

\subsection{Future Directions for Study}

This study provided predictors and effectors of whether RDs currently or intend to teach fresh vegetable food safety that could be factored into food safety curriculum for dietitians. The next step would be to create an intervention study, using the TPB, which assesses the behavioral outcomes of RDs after being exposed to two different fresh vegetable food safety curriculums. One curriculum would teach 
from a "bottom up" approach and include the predictors and effectors of teaching fresh vegetable food safety, while the alternative curriculum would focus on staying true to the current system of teaching from a "top down" approach and provide RDs information that experts think they should know. The study would include a pre and post survey for the RDs, one time before the intervention and another time after the intervention. This would allow us to measure the direct effects of each independent belief variable, independent of behavioral intention, on current teaching behavior.

Future research could include two alternative belief variables, personal norm and moral norms, could be assessed, as they have been found to explain significant portions of variance in behaviors (26). Personal norm refers to a person's perception of how someone like him/herself should behave. Moral norms are feelings of personal responsibility regarding the behavior.

Lastly it would be useful to determine the antecedent variables leading to perceived behavioral control, attitudes, and subjective norm. For example, past experience with a behavior may have an important effect on each of these belief variables. By determining the antecedent variables of the three belief variables, educators could go a step further in the creations of their curriculums by focusing on ways to modify RD's beliefs about teaching fresh vegetable food safety, rather than just including these beliefs in their curriculum. 


\section{BIBLIOGRAPHY}

1. Food and Drug Administration. Guide to minimize microbial food safety hazards of fresh-cut fruits and vegetables. The Food and Drug Administration Web site. http://www.cfsan.fda.gov/ dms/prodgui4.html. Accessed March, 2009.

2. Center for Disease Control. Family reunion health and safety tips. The Center For Disease Control Web site. www.cdc.gov/family/reunions/. Accessed November 4, 2008.

3. Palumbo M, Gorny J, Gombas D. Recommendations for handling fresh-cut leafy green salads by consumers and retail foodservice operators. Food Protection Trends. 2007;27(11):892-898.

4. Palmer S. The E.coli outbreak; Lettuce learn a lesson. Today's Dietitian. 2007;9(1):28-32.

5. United States Departments of Health \& Human Services, US Department of Agriculture. Dietary Guidelines For Americans, 2005. $6^{\text {th }}$ Ed. Washington, DC: US Government Printing Office; 2005.

6. United States Department of Agriculture. MyPyramid.gov. United States Department of Agriculture Web site. http://www.mypyramid.gov/. Accessed March, 2008.

7. American Dietetic Association, Commission on Accreditation for Dietetics Education. Dietetics Education Curriculum Requirements - 2008 Accreditation Standards. The American Dietetic Association Web site. http://www.eatright.org/cps/rde/xchg/ada/hs.xsl/CADE 813 ENU HTML.htm. Accessed November 9, 2008. 
8. Griffin RJ, Dunwoody S, Neuwirth K, Giese J. Linking the heuristic-systematic model and depth of processing. Communication Research. 2002;29(6):705-732.

9. Ajzen I. The theory of planned behavior. Organ Behav Hum Decis Process. 1991;50:179-211.

10. Ajzen I. Attitudes, Personality, and Behavior. United Kingdom: Open University Press; 1988.

11. Fishbein M, Ajzen I. Belief, Attitude, Intentions, and Behavior: An Introduction to Theory and Research. Reading, MA: Addison-Wesley; 1975.

12. Griffin R, Dunwoody S, Neuwirth K. Proposed model of the relationship of risk information seeking and processing to the development of preventive behaviors. Environmental Research. 1999;Section A80:S230-S245.

13. Griffin R, Neuwirth K, Dunwoody S, Giese J. Information sufficiency and risk communication. Media Psychology. 2004;6:23-61.

14. Coulston A. President's page: Personal responsibility and food safety. J Am Diet Assoc. 1999;99(2):236-237.

15. Aruscavage D, Miller S, Lewis Ivey M, Lee K, LeJeune J. survival and dissemination of escherichia coli $0157: \mathrm{H} 7$ on physically and biologically damaged lettuce plants. Journal of Food Protection. 2008;71(12):2384-2388.

16. Ilic S, Odomeru J, LeJeune J. Coliforms and prevalence of esterichia coli and foodborne pathogens on minimally processed spinach in two packing plants. Journal of Food Protection. 2008;71(12):2398-2403.

17. Gilbert S, Cressey P. Consumer knowledge, attitudes and beliefs with respect to campylobacter, campylobacteriosis and poultry. New Zealand Food Safety Authority Web site. www.nzfsa.govt.nz. Accessed March 2009.

18. Food Marketing Institute. Food safety and foodborne illnesses. Food Marketing Institute Web site. Www.fmi.org/foodsafety/fscenter/. Accessed December, 2008.

19. International Food Information Council Foundation. 2009 food $\&$ health results web cast. International Food Information Council Foundation Web site. http://www.ific.org/research/foodandhealthsurvey.cfm. Accessed June 2009.

20. American Dietetic Association Accreditation and Education Programs. For registered dietitian, a food and nutrition expert, educational and professional requirements. The American Dietetic Association Web site. 
http://www.eatright.org/cps/rde/xchg/ada/hs.xsl/CADE_748_ENU_HTML.htm. Accessed March 2009.

21. Sneed J, Strohbehn C. Trends impacting food safety in retail foodservice: Implications for dietetics practice. J Am Diet Assoc. 2008;108(7):1170-1177.

22. Commission on Dietetic Registration. About CDR. American Dietetic Association Web site. http://cdrnet.org/about/index.htm. Accessed July 12, 2009.

23. Ajzen I, Madden TJ. Prediction of goal-directed behavior: attitudes, intentions, and perceived behavioral control. Journal of Experimental Social Psychology. 1986;22:453-574.

24. Godin G, Kok G. The theory of planned behavior: A review of its applications to health-related behaviors. Am J Health Promot. 1996;11(2):87-96.

25. Ajzen I. Perceived behavioral control, self-efficacy, locus of control, and the theory of planned behavior. Journal of Applied Social Psychology. 2002;32(4):665683.

26. Courneya KS, Bobick TM, Schinke RJ. Does the theory of planned behavior mediate the relationship between personality and exercise behavior? Basic and Applied Social Psychology. 1999;21:317-324.

27. Sheeran P, Orbell S. Implementation intentions and repeated behaviour: Augmenting the predictive validity of the theory of planned behaviour. European Journal of Social Psychology. 1999;29:349-369.

28. Ajzen, I. Theory of planned behavior frequently asked questions. University of Massachusetts Web site. http://people.umass.edu/aizen/faq.html. Accessed July 2, 2009.

29. Millstein S. Utilities of the theories of reasoned action and planned behavior for predicting physician's behavior: A prospective study. Health Psychology. 1996;15(5):398-402.

30. Burak L. Examination and prediction of elementary school teachers' intentions to teach HIV/AIDS education. Education and Prevention. 1994;6(4):310-321.

31. Schifter D, Ajzen I. Intention, perceived control, and weight loss: An application of the theory of planned behavior. J Pers Soc Psychol. 1985;49(3):843-851.

32. Chase K, Reicks M, Jones J. Applying the theory of planned behavior to promotion of whole-grain foods by dietitians. J Am Diet Assoc. 2003;103(12):16391642. 
33. Sjoberg S, Kyungwon K, Reicks M. Applying the theory of planned behavior to fruit and vegetable consumption by older adults. J Nutr Elder. 2004;23(4):35-46.

34. Seaman P, Eves A. Food hygiene training in small to medium-sized care settings. Int J Environ Health Res. 2008;18(5):365-374.

35. Salomon S. Diversifying dietetics; A challenge that's well worth the effort. Today's Dietitian. 2009;11(13):26-30.

36. United States Census Bureau. Census regions and divisions of the United States. The United States Census Bureau Web site.

www.census.gov/geo/www/us_regdiv.pdf. Accessed May 2009.

37. Hasenecz N. Consumers drive back-to-basics food trend. Today's Dietitian. 2009;11(9):38-41.

38. Hemmelgarn M. Bacteria and beyond; Getting to the root of food safety issues. Today's Dietitian. 2009;11(6):56-57.

39. United States Environmental Protection Agency. The food quality protection act (FQPA) background. United States Environmental Protection Agency Web site. http://www.epa.gov/opp00001/regulating/laws/fqpa/backgrnd.htm. Accessed June, 2009.

40. Worthington V. Nutritional quality of organic versus conventional fruits, vegetables, and grains. J Altern Complement Med. 2001:161-173.

41. McCabe-Sellers B, Beattie S. Food safety: Emerging trends in foodborne illness surveillance and prevention. J Am Diet Assoc. 2004;104:1708-1718.

42. Grieger L. To degree or not to degree? Today's Dietitian. 2005;7(7):31-33. 


\section{APPENDIX A: ADVERTISEMENT FOR SURVEY}

\section{Registered Dietitians Needed To Participate in Short Food Safety Survey}

Researchers with the Departments of Human Nutrition at The Ohio State University are seeking Registered Dietitians who are currently employed in a position for which they directly educate clients/patients, other than academia classroom education. To participate in this survey, you must be at least 18 years of age.

\section{Purpose:}

The purpose of this research is to determine the registered dietitian's (RD) personal characteristics, beliefs and attitudes about fresh vegetable food safety and do these characteristics, beliefs and attitudes predict whether or not the RD will integrate food safety recommendations into their client/patient education about fresh vegetables.

Time Involved: The survey will take between 60-90 minutes to complete

\section{Compensation:}

As a thank you for participating in this survey you will be given a choice of $\$ 50$ gift certificates from places such as Walmart, Target, Barnes and Noble, Bed Bath and Beyond and Starbucks.

To access the survey, click on the link below:

http://ehe.osu.edu/rdsurvey/

For more information, e-mail Lydia C. Medeiros, Ph.D., RD at medeiros.1@osu.edu

Thanks for your participation. 


\title{
APPENDIX B: INTRODUCTORY PAGE AND WAIVER OF CONSENT
}

\author{
Version 1, November 17, 2008, Medeiros \\ Welcome to the Vegetable Food Safety Survey For Registered Dietitians \\ Registered Dietitian's Food Safety Information Processing Techniques \\ and \\ Subsequent Education Practices \\ USDA-NIFSI Grant \# 60015618 \\ Dr. Lydia Medeiros, Principal Investigator
}

Objectives: The objectives of this study are to determine the individual characteristics of registered dietitians, and their personal beliefs and attitudes related to food safety of fresh vegetables, that predict either intention or actual teaching of fresh vegetable food safety to clients/patients.

Participation Requirements: To participate in this survey, you must be at least 18 years of age and a registered dietitian currently involved in direct client/patient education. If academic classroom education is the limit of your involvement in education, this is not considered direct client/patient education, and you do not qualify for this study.

Benefits and Risks: It is not possible to identify all potential risks in research procedures, but the researcher(s) have taken reasonable safeguards to minimize any known and potential, but unknown, risks. Data will be collected on encrypted, secure servers, and data analysis will be completed on encrypted computers. Results of this study will provide a better idea of what registered dietitians need to know and/or learn in order to teach vegetable food safety. Benefits to clients/patients will be an increase in education about safe fresh vegetable food handling.

Compensation: At the completion of this survey you will be directed to a page that will ask you for your choice of fifty dollar gift certificate out of several options, including Bed Beth and Beyond, Target, Walmart, Starbucks and Barnes and Noble. You will be asked to provide your mailing information in order for assured delivery of compensation. After the gift certificate has been sent, mailing information will be destroyed. 
To Complete the Study: Click on the link below. You will first access the consent form that must be read and agreed to before entering the survey. The next screen begins the survey, which will take 60-90 minutes to complete. If you need to stop the survey before you have completed, you may close out of the survey and continue at a later time. If you decide to do this you will need to use the same computer and web browser as the one you used to start the survey, and you must return and finish the survey within 10 days. After completing the survey and submitting the results, another link will send you to a page with a registration form for your name, mailing address, and choice of gift certificate.

Thank you for taking part in this survey!

\section{THE OHIO STATE UNIVERSITY}

\section{INFORMED CONSENT TO PARTICIPATE IN A RESEARCH}

\section{PROJECT}

TITLE OF PROJECT: Registered Dietitian's Food Safety Information Processing Techniques and Subsequent Education Practices

NAME OF PRINCIPAL INVESTIGATOR: Lydia C. Medeiros, PhD., R.D. (OSU Principal Investigator) and Janet Buffer, R.D, L.D, M.S (OSU Co-Principal Investigator)

SPONSOR OF PROJECT: United States Department of Agriculture-Cooperative State Research, Education and Extension Service (USDA-CSREES)

THIS IS A CONSENT FORM FOR RESEARCH PARTICIPATION. It contains important information about this study and what to expect if you decide to participate.

OBJECTIVES: The objective of this study is to determine the individual characteristics of registered dietitians, and their personal beliefs related to food safety of fresh vegetables, that predict either intention or actual teaching of fresh vegetable food safety to clients/patients.

PROCEDURES/TASKS: An advertisement was sent to you electronically with instructions for accessing the website and the survey. Upon completion of the survey, you will be asked to provide us with a mailing address where we can send your gift certificate of choice. The survey will take approximately 60-90 minutes to complete.

DURATION: You may leave and return to the study at any time. If you decide to stop entering data in the study without completing, there will be no penalty to you, and 
you will not lose any benefits to which you are otherwise entitled. Your decision will not affect your future relationship with The Ohio State University.

MINIMAL REQUIREMENTS OF PARTICIPANTS: To participate in this survey, you must be at least 18 years of age and a dietitian currently involved in direct client/patient education. If academia classroom education is the limit of your involvement in education, this is not considered direct client/patient education, and you do not qualify for this study.

RISKS AND BENEFITS: It is not possible to identify all potential risks in research procedures, but the researcher(s) have taken reasonable safeguards to minimize any known and potential, but unknown, risks.

CONFIDENTIALITY: Efforts will be made to keep your study-related information confidential. The data will be identified by user ID code, which is randomly selected by the survey program. There will never be an actual name attached to the data. All data will be collected and stored on encrypted and secure servers located in The Ohio State University's Kinnear Center. Data will be moved to removable CD-rom for data analyses, after closing of the survey. No identifying information, other than ID code, will be attached to the data. Although every effort to protect confidentiality will be made, no guarantee of internet survey security can be given, as, although unlikely, transmissions can be intercepted and IP addresses can be identified.

However, there may be circumstances where this information must be released. For example, personal information regarding your participation in this study may be disclosed if required by state law. Also, your records may be reviewed by the following groups (as applicable to the research):

* Office for Human Research Protections or other federal, state, or international regulatory agencies;

* The Ohio state University Institutional Review Board or Office of Responsible Research Practices;

* The sponsor, if any, or agency (including the Food and Drug Administration for FDA-regulated research) supporting the study.

INCENTIVES: At the completion of this survey you will be directed to a page that will ask you for your choice of fifty dollar gift certificate out of several options, including Bed Beth and Beyond, Target, Walmart, Starbucks and Barnes and Noble. You will be asked to provide your mailing information in order for assured delivery of compensation. Your personal information will not be kept after we have mailed your gift card. There will be no way that we or anyone else can match your address with your study data.

PARTICIPANT RIGHTS: You may refuse to participate in this study without penalty or loss of benefits to which you are otherwise entitled. If you are a student or 
employee at Ohio State, your decision will not affect your grades or employment status

If you choose to participate in the study, you may discontinue participation at any time without penalty or loss of benefits. By submitting this form, you do not give up any personal legal rights you may have as a participant in this study.

An Institutional Review Board responsible for human subjects' research at The Ohio State University reviewed this research project and found it to be acceptable, according to applicable state and federal regulations and University policies designed to protect the rights and welfare of participants in research.

Contacts and Questions: For questions, concerns, or complaints about the study you may contact Lydia C. Medeiros, PhD., RD 614-292-2699. Email: medeiros.1@osu.edu.

For questions about your rights as a participant in this study or to discuss other study-related concerns or complaints with someone who is not part of the research team, you may contact Ms. Sandra Meadows in the Office of Responsible Research Practices at 1-800-678-6261.

If you are injured as a result of participating in this study or for questions about a study-related injury, you may contact Lydia C. Medeiros, PhD., R.D. 614292-2699. Email: medeiros.1@osu.edu.

HUMAN SUBJECT STATEMENT: I am at least 18 years of age and am a registered dietitian who educates clients/patients, not limited to academic education. I have had the opportunity to read this consent form, ask questions about the research and am prepared to participate in this project. I am not giving up any legal rights by submitting this form. 


\section{APPENDIX C: SURVEY}

Version 2, November 17, 2008, Medeiros

\section{Dietitian's Food Safety and Health Survey}

The goal of this research is to determine the Registered Dietitian's (RD) personal characteristics, beliefs and attitudes about fresh vegetable food safety and do these characteristics, beliefs and attitudes predict whether or not the RD will integrate food safety recommendations into their client/patient education about fresh vegetables.

This research is based on the latest statistics that indicate an increase in the numbers of foodborne illnesses coming from fresh vegetables. Since registered dietitians are often promoting the consumption of fresh vegetables, it is important to begin integrating safety precautions in these recommendations. We realize that you may not do this, and that is fine. We want you to BASE ALL ANSWERS ON YOUR CURRENT THOUGHTS AND BELIEFS, not what you think WE want you to do. Honest answers help us conduct a more valid survey with the most accurate results. If you have more than one employment position, answer for the one that requires the most time in direct client/patient education.

For purposes of this survey, we will define "fresh vegetables" as: Not having its original qualities altered by processing (canning, freezing, cooking) of any kind, but may be washed and packaged for retail sale. Think of the vegetables you would find in your grocery store's produce section. For this research, we are especially focusing on fresh and uncooked tomatoes and green leafy vegetables (eg. Leaf lettuce, romaine, spinach etc.).

Directions: Read through each question and provide your desired answer, based on your current thoughts and beliefs. If you do not wish to answer the question you may select "I choose not to answer this question". In order to proceed to the next question you must either answer the question, or mark that you do not wish to answer. Please take your time and provide your most honest answer. This survey should take anywhere between 1-1.5 hours to complete. If you find you are loosing your concentration and/or need to leave the survey for any reason, you may exit the survey and continue with the survey at a later time. To do so, however, you must use the same computer and same web browser as the one you were using when you began the survey.

Filter Questions:

\begin{tabular}{|l|l|l|}
\hline Are you older than 18? & Yes No & $\begin{array}{l}\text { One answer allowed, if no, } \\
\text { then cannot participate }\end{array}$ \\
\hline $\begin{array}{l}\text { Do you educate } \\
\text { clients/patients, other than as } \\
\text { part of an academic } \\
\text { curriculum? }\end{array}$ & Yes No & $\begin{array}{l}\text { One answer allowed, if no, } \\
\text { then cannot participate }\end{array}$ \\
\hline \begin{tabular}{l} 
Are you a registered dietitian? \\
\hline
\end{tabular} & Yes No & One answer allowed, if no, \\
\hline
\end{tabular}


Sorry, but according to one or more of your previous answers, you are not eligible for our study. Thank you for your time and for considering to participate.

* Indicates that a response is needed, and is located next to every question on the survey.

\begin{tabular}{|c|c|c|}
\hline 1. Gender & $\begin{array}{l}\text { Male Female } \\
\text { I choose not to answer }\end{array}$ & $\begin{array}{l}\text { Single answer question } \\
0=\text { male } \\
1=\text { female } \\
99=\text { choose not to } \\
\text { answer }\end{array}$ \\
\hline $\begin{array}{l}\text { 2. Which ethnic group do you } \\
\text { identify yourself with? }\end{array}$ & $\begin{array}{l}\text { 1) White/Non-Hispanic } \\
\text { 2) Hispanic/Latino } \\
\text { 3) American Indian or Alaska } \\
\text { Native } \\
\text { 4) Asian or Pacific Islander } \\
\text { 5) Black/African-American } \\
\text { 6) I choose not to answer this } \\
\text { question }\end{array}$ & $\begin{array}{l}\text { Single answer question } \\
\text { Coded } 1 \text { through } 5 \text {, as } \\
\text { written } \\
\# 6=99\end{array}$ \\
\hline 3.What is your age category? & $\begin{array}{l}\text { 1) 18-29 years } \\
\text { 2) } 30-44 \text { years } \\
\text { 3) } 45-59 \text { years } \\
\text { 4) } 60-74 \text { years } \\
\text { 5) } 75+\text { years } \\
\text { 6) I choose not to answer this } \\
\text { question }\end{array}$ & $\begin{array}{l}\text { Single answer question } \\
\text { Coded } 1 \text { through } 5 \text {, as } \\
\text { written } \\
\# 6=99\end{array}$ \\
\hline $\begin{array}{l}\text { 4. What is the highest grade or } \\
\text { year of school that you have } \\
\text { completed? }\end{array}$ & $\begin{array}{l}\text { (1) College graduate } \\
\text { (2) Postgraduate or professional } \\
\text { (5) I choose not to answer this } \\
\text { question }\end{array}$ & $\begin{array}{l}\text { Single answer question } \\
\text { Coded } 1 \text { through } 4 \text {, as } \\
\text { written } \\
\# 5=99\end{array}$ \\
\hline $\begin{array}{l}\text { 5. Roughly, what was your total } \\
\text { household income last year from } \\
\text { all sources? }\end{array}$ & $\begin{array}{ll}\text { 1) } & \text { Less than } \$ 35,000 \\
\text { 2) } & \$ 45,000-54,000 \\
\text { 3) } & \$ 55,000-64,000 \\
\text { 4) } & \$ 65,000-74,000 \\
\text { 5) } & \$ 75,000-84,000 \\
6) & \$ 85,000-99,000 \\
\text { 7) } 100,000 \text { or more } \\
\text { 8) I choose not to answer this } \\
\text { question }\end{array}$ & $\begin{array}{l}\text { Single answer question } \\
\text { Coded } 1 \text { through } 7 \text {, as } \\
\text { written. } \\
\# 8=99\end{array}$ \\
\hline $\begin{array}{l}\text { 6. How do you rate your political } \\
\text { philosophy? }\end{array}$ & $\begin{array}{l}\text { 1) very liberal } \\
\text { 2) liberal } \\
\text { 3) neutral } \\
\text { 4) conservative } \\
\text { 5) very conservative } \\
\text { 6) I choose not to answer this } \\
\text { question }\end{array}$ & $\begin{array}{l}\text { Single answer question } \\
\text { Coded } 1 \text { through } 5 \text {, as } \\
\text { written } \\
\# 6=99\end{array}$ \\
\hline $\begin{array}{l}\text { 7. What is the primary state in } \\
\text { which you practice? }\end{array}$ & & Fill in the blank \\
\hline
\end{tabular}




\begin{tabular}{|c|c|c|c|c|}
\hline \multicolumn{5}{|l|}{ opinion. } \\
\hline $\begin{array}{l}\text { 8. I have a sufficient amount of } \\
\text { knowledge about fresh vegetable } \\
\text { food safety for my personal use } \\
\text { and safety. } \\
\text { **internal locus of control } \\
\text { Control belief/slef-efficacy }\end{array}$ & \multicolumn{2}{|c|}{\begin{tabular}{|l} 
5)strongly agree \\
4)agree \\
3) not sure \\
2) disagree \\
1) strongly disagree \\
6) I choose not to answer \\
this question
\end{tabular}} & \multicolumn{2}{|c|}{$\begin{array}{l}\text { Single answer question } \\
\text { Coded as written } \\
\# 6=99\end{array}$} \\
\hline $\begin{array}{l}\text { 9. I have a sufficient amount of } \\
\text { knowledge about the food safety of } \\
\text { fresh vegetables to educate my } \\
\text { clients/patients. } \\
\text { (Please answer this question even } \\
\text { if you do not educate on fresh } \\
\text { vegetable food safety) } \\
* * \text { internal locus of control } \\
\text { Control belief/self-efficacy }\end{array}$ & $\begin{array}{l}\text { 5)strongly } \\
\text { 4)agree } \\
\text { 3) not sur } \\
\text { 2) disagre } \\
\text { 1) strongl } \\
\text { 6) I choos } \\
\text { question }\end{array}$ & $\begin{array}{l}\text { gree } \\
\text { disagree } \\
\text { not to answe }\end{array}$ & & $\begin{array}{l}\text { Single answer question } \\
\text { Coded as written } \\
\# 6=99\end{array}$ \\
\hline $\begin{array}{l}\text { 10. Please respond to one of the } \\
\text { following statements: }\end{array}$ & $\begin{array}{l}\text { 3) I currently to } \\
\text { about fresh veg } \\
\text { 2) Even though } \\
\text { my clients/patie } \\
\text { food safety I pla } \\
\text { 1) I don't and n } \\
\text { clients/patients } \\
\text { food safety. }\end{array}$ & $\begin{array}{l}\text { able my clients } \\
\text { I dood saf } \\
\text { ts about fresh } \\
\text { to in the fut } \\
\text { ver plan to te: } \\
\text { bout fresh ves }\end{array}$ & $\begin{array}{l}\text { tients } \\
\text { teach } \\
\text { getable } \\
\text { my } \\
\text { ble }\end{array}$ & $\begin{array}{l}\text { Single answer question } \\
\text { Coded as written } \\
\text { Skip pattern: If answer } \\
\text { is } 2 \text { or } 1 \text {, skip number } \\
11 \text { and go straight to } \\
\text { number } 12\end{array}$ \\
\hline \multicolumn{5}{|c|}{ For each of the following questions, choose your best answer: } \\
\hline $\begin{array}{l}\text { 11. What may trigger you to } \\
\text { provide food safety information to } \\
\text { your client? Choose the response } \\
\text { that BEST describes your common } \\
\text { practice. }\end{array}$ & $\begin{array}{l}\text { 1) } \\
\text { 2) }\end{array}$ & $\begin{array}{l}\text { Standard pro } \\
\text { with all clie } \\
\text { Standard pro } \\
\text { client has a } \\
\text { medical con } \\
\text { as gestation } \\
\text { HIV/AIDS, } \\
\text { that compro } \\
\text { immune sys } \\
\text { Provide only } \\
\text { client/patien } \\
\text { about a food } \\
\text { practice } \\
\text { Provide if cl } \\
\text { indicates a r } \\
\text { safety practi } \\
\text { diet recall, } n \\
\text { assessment, } \\
\text { Provide only } \\
\text { extra time to } \\
\text { such inform } \\
\text { Provide only } \\
\text { food outbrea }\end{array}$ & $\begin{array}{l}\text { lure } \\
\text { patients. } \\
\text { dure if } \\
\text { cific } \\
\text { on such } \\
\text { iabetes, } \\
\text { ancer } \\
\text { es their } \\
\text { ks } \\
\text { fety } \\
\text { t/patient } \\
\text { food } \\
\text { through } \\
\text { tion } \\
\text { I have } \\
\text { clude } \\
\text { n. } \\
\text { a recent } \\
\text { from }\end{array}$ & $\begin{array}{l}\text { Coded as written } \\
\qquad \# 7=99 \\
\text { Skip pattern: Those } \\
\text { who answer this } \\
\text { question will then skip } \\
\text { number } 12 \text { and go } \\
\text { straight to } 13 \text {. }\end{array}$ \\
\hline
\end{tabular}




\begin{tabular}{|c|c|c|}
\hline & $\begin{array}{l}\text { fresh vegetables) has } \\
\text { occurred. } \\
\text { 7) I choose not to answer } \\
\text { this question } \\
\text { 8) Other. Please } \\
\text { specifically describe: } \\
\text { (Please do not include } \\
\text { quotes [" "] or apostrophes } \\
\text { ['] as part of your response) }\end{array}$ & \\
\hline $\begin{array}{l}\text { 12. Why don't you teach fresh } \\
\text { vegetable food safety information } \\
\text { to your clients/patients? }\end{array}$ & $\begin{array}{l}\text { 1) I do not know enough } \\
\text { about fresh vegetable } \\
\text { food safety. } \\
\text { 2) } \\
\text { I do not have the time } \\
\text { to teach about fresh } \\
\text { vegetable food safety. } \\
\text { 3) I do not think fresh } \\
\text { vegetable food safety is } \\
\text { important. } \\
\text { 4) My employer will not } \\
\text { allow me to do so. } \\
\text { 5) OTHER (please be } \\
\text { specific and please do } \\
\text { not include quotes [" "] } \\
\text { or apostrophes ['] as } \\
\text { part of your response) } \\
\text { I do not choose to } \\
\text { answer this question. }\end{array}$ & $\begin{array}{l}\text { Coded as written } \\
\text { Text box number } 4 \\
\text { Number } 6=99\end{array}$ \\
\hline \multicolumn{3}{|c|}{$\begin{array}{l}\text { Read each of the following statements and mark the box that is the closest match to your own } \\
\text { opinion. }\end{array}$} \\
\hline $\begin{array}{l}\text { 13. Including information about } \\
\text { the food safety of fresh vegetables } \\
\text { in each of my education sessions } \\
\text { would be: } \\
\text { Perceieved power }\end{array}$ & $\begin{array}{ll}\text { 1) } & \text { Definitely impossible } \\
\text { 2) Impossible } \\
\text { 3) } \\
\text { 4) } \text { Pot sure } \\
\text { 5) Dessible } \\
\text { 6) } \text { I do not choose to } \\
\\
\text { answer this question }\end{array}$ & $\begin{array}{l}\text { Coded as written } \\
\# 6=99\end{array}$ \\
\hline $\begin{array}{l}\text { 14. I have control over whether or } \\
\text { not I teach my clients/patients } \\
\text { about fresh vegetable food safety: } \\
\text { ** More control } \\
\text { Perceieved power }\end{array}$ & $\begin{array}{l}\text { 5)Strongly Agree } \\
\text { 4)Agree } \\
\text { 3)Not sure } \\
\text { 2)Disagree } \\
\text { 1)Strongly Disagree } \\
\text { 6)I do not choose to answer this } \\
\text { question. }\end{array}$ & $\begin{array}{l}\text { Coded as written } \\
\# 6=99\end{array}$ \\
\hline \multicolumn{3}{|c|}{ For each of the following questions, choose your best answer: } \\
\hline $\begin{array}{l}\text { 15. Do you consider yourself part } \\
\text { of a high-risk population for } \\
\text { foodborne illness? ie. pregnancy, } \\
\text { elderly, immunocompromised due } \\
\text { to a specific disease state or }\end{array}$ & $\begin{array}{l}\text { 1) Yes } \\
\text { 2) No } \\
\text { 3) I choose not to answer this } \\
\text { question }\end{array}$ & $\begin{array}{l}\text { Coded as written } \\
3=99\end{array}$ \\
\hline
\end{tabular}




\begin{tabular}{|c|c|c|}
\hline medication use) & & \\
\hline $\begin{array}{l}\text { 16. To what extent do you believe } \\
\text { that your actions affect your } \\
\text { health? }\end{array}$ & $\begin{array}{l}\text { 4)A great deal } \\
\text { 3)Some } \\
\text { 2)Not much } \\
\text { 1)Not at all } \\
\text { 5) I choose not to answer } \\
\text { this question }\end{array}$ & $\begin{array}{l}\text { Single answer question } \\
\text { Coded as written } \\
\qquad \# 5=99\end{array}$ \\
\hline $\begin{array}{l}\text { 17. To what extent do you believe } \\
\text { that your actions affect the health } \\
\text { of others? }\end{array}$ & $\begin{array}{l}\text { 4)A great deal } \\
\text { 3)Some } \\
\text { 2)Not much } \\
\text { 1) Not at all } \\
\text { 5) I choose not to answer } \\
\text { this question }\end{array}$ & $\begin{array}{l}\text { Single answer question } \\
\text { Coded as written } \\
\# 5=99\end{array}$ \\
\hline $\begin{array}{l}\text { 18. Have you ever been medically } \\
\text { diagnosed with a foodborne } \\
\text { illness? } \\
\text { PBC? } \\
\text { Control belief }\end{array}$ & $\begin{array}{l}\text { 1) Yes } \\
\text { 2) No } \\
\text { 3) Don't remember/don't know } \\
\text { 4) I choose not to answer this } \\
\text { question }\end{array}$ & 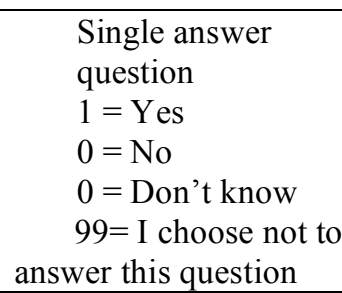 \\
\hline $\begin{array}{l}\text { 19. Have you had a foodborne } \\
\text { illness, but did not seek medical } \\
\text { care? }\end{array}$ & $\begin{array}{l}\text { 1) Yes } \\
\text { 2) No } \\
\text { 3) Don't remember/don't know } \\
\text { 4) I choose not to answer this } \\
\text { question }\end{array}$ & $\begin{array}{l}\text { Single answer question } \\
\quad 0=\text { Yes } \\
1=\text { No } \\
0=\text { Don't know } \\
99=\text { I choose not to } \\
\text { answer this question }\end{array}$ \\
\hline $\begin{array}{l}\text { 20. Have any of your close friends } \\
\text { or relatives ever been medically } \\
\text { diagnosed with a foodborne } \\
\text { illness? } \\
\text { PBC? } \\
\text { Control belief }\end{array}$ & $\begin{array}{l}\text { 1) Yes } \\
\text { 2) No } \\
\text { 3) Don't remember/don't know } \\
\text { 4) I choose not to answer this } \\
\text { question }\end{array}$ & $\begin{array}{l}\text { Single answer question } \\
\begin{array}{l}1=\text { Yes } \\
0=\text { No } \\
0=\text { Don't know } \\
99=\text { I choose not } \\
\text { to answer this } \\
\text { question }\end{array}\end{array}$ \\
\hline $\begin{array}{l}\text { 21. Do you believe that any of } \\
\text { your close friends or relatives have } \\
\text { had foodborne illness, but did not } \\
\text { seek medical care? }\end{array}$ & $\begin{array}{l}\text { 1) Yes } \\
\text { 2) No } \\
\text { 3) Don't remember/don't know } \\
\text { 4) I choose not to answer this } \\
\text { question }\end{array}$ & $\begin{array}{l}\text { Single answer question } \\
\qquad \begin{aligned} 0=\text { Yes } \\
1=\text { No } \\
0=\text { Don't know } \\
99=\text { I choose not } \\
\text { to answer this question }\end{aligned}\end{array}$ \\
\hline $\begin{array}{l}\text { 22. Have any of your } \\
\text { clients/patients ever been } \\
\text { medically diagnosed with a } \\
\text { foodborne illness? }\end{array}$ & $\begin{array}{l}\text { 1) Yes } \\
\text { 2) No } \\
\text { 3) Don't remember/don't know } \\
\text { 4) I choose not to answer this } \\
\text { question }\end{array}$ & $\begin{array}{l}\text { Single answer question } \\
\begin{aligned} 1=\text { Yes } \\
0=\text { No } \\
0=\text { Don't know } \\
99=\text { I choose not } \\
\text { to answer this }\end{aligned}\end{array}$ \\
\hline $\begin{array}{l}\text { 23. Do you believe that any of } \\
\text { your clients have had foodborne } \\
\text { illness, but did not seek medical } \\
\text { care? }\end{array}$ & $\begin{array}{l}\text { 1) Yes } \\
\text { 2) No } \\
\text { 3) Don't remember/don't know } \\
\text { 4) I choose not to answer this } \\
\text { question }\end{array}$ & $\begin{array}{l}\text { Single answer question } \\
\begin{aligned} 0 & =\text { Yes } \\
1 & =\text { No } \\
0 & =\text { Don't know }\end{aligned}\end{array}$ \\
\hline
\end{tabular}




\begin{tabular}{|c|c|c|}
\hline & & $\begin{array}{l}\quad 99=\text { I choose not } \\
\text { to answer this }\end{array}$ \\
\hline \multicolumn{3}{|c|}{$\begin{array}{l}\text { Read each of the following statements and mark the box that is the closest match to your own } \\
\text { opinion. }\end{array}$} \\
\hline $\begin{array}{l}\text { 24. People who are important to } \\
\text { me would expect me to stay on top } \\
\text { of information about the food } \\
\text { safety of fresh vegetables. }\end{array}$ & $\begin{array}{l}\text { 5) Strongly agree } \\
\text { 4) Agree } \\
\text { 3) Neutral } \\
\text { 2) Disagree } \\
\text { 1) Strongly disagree } \\
\text { 6) I choose not to answer } \\
\text { this question }\end{array}$ & $\begin{array}{l}\text { Single answer question } \\
\text { Coded as written } \\
\# 6=99\end{array}$ \\
\hline $\begin{array}{l}\text { 25. My clients/patients expect me } \\
\text { to teach them about the food safety } \\
\text { of fresh vegetables. }\end{array}$ & $\begin{array}{cl}\text { 5) } & \text { Strongly agree } \\
\text { 4) Agree } \\
\text { 3) Neutral } \\
\text { 2) Disagree } \\
\text { 1) Strongly disagree } \\
\text { 6) I choose not to answer } \\
\text { this question }\end{array}$ & $\begin{array}{l}\text { Single answer question } \\
\text { Coded as written } \\
\# 6=99\end{array}$ \\
\hline $\begin{array}{l}\text { 26. Generally speaking I want to } \\
\text { do what my clients/patients think I } \\
\text { should do. }\end{array}$ & $\begin{array}{l}\text { 5) Strongly agree } \\
\text { 4) Agree } \\
\text { 3) Neutral } \\
\text { 2) Disagree } \\
\text { 1) Strongly disagree } \\
\text { 6) I choose not to } \\
\text { answer this question } \\
\end{array}$ & $\begin{array}{l}\text { Single answer question } \\
\text { Coded as written } \\
\# 6=99\end{array}$ \\
\hline $\begin{array}{l}\text { 27. Generally speaking I want to } \\
\text { do what people who are important } \\
\text { to me think I should do. }\end{array}$ & $\begin{array}{l}\text { 5) Strongly agree } \\
\text { 4) Agree } \\
\text { 3) Neutral } \\
\text { 2) Disagree } \\
\text { 1) Strongly disagree } \\
\quad \text { 6) I choose } \\
\text { not to answer this question }\end{array}$ & $\begin{array}{l}\text { Single answer question } \\
\text { Coded as written } \\
\# 6=99\end{array}$ \\
\hline \multicolumn{3}{|c|}{ Read each of the following statements. Mark the box that is the closest match to your own opinion. } \\
\hline $\begin{array}{l}\text { 28. In my life, it would be easy for } \\
\text { me to avoid becoming ill from } \\
\text { foodborne illness caused by a fresh } \\
\text { vegetables. }\end{array}$ & $\begin{array}{l}\text { 5) strongly agree } \\
\text { 4) agree } \\
\text { 3) neutral } \\
\text { 2) disagree } \\
\text { 1) strongly disagree } \\
\text { 6) I choose not to answer this } \\
\text { question }\end{array}$ & $\begin{array}{l}\text { Single answer question } \\
\text { Coded } 1 \text { through } 5 \text {, as } \\
\text { written } \\
\# 6=99\end{array}$ \\
\hline $\begin{array}{l}\text { 29. In my patient's/client's lives it } \\
\text { would be easy for them to avoid } \\
\text { becoming ill from foodborne } \\
\text { illness caused by a fresh vegetables } \\
* * \text { Sugested by Griffin et. al as a } \\
\text { PBC } \\
\text { Control belief }\end{array}$ & $\begin{array}{l}\text { 5) strongly agree } \\
\text { 4) agree } \\
\text { 3) neutral } \\
\text { 2) disagree } \\
\text { 1) strongly disagree } \\
\text { 6) I choose not to answer this } \\
\text { question }\end{array}$ & $\begin{array}{l}\text { Coded } 1 \text { through } 5 \text {, as } \\
\text { written } \\
\# 6=99\end{array}$ \\
\hline $\begin{array}{l}\text { 30. Government officials care } \\
\text { about the health and safety of } \\
\text { people like me. }\end{array}$ & $\begin{array}{l}\text { 5) strongly agree } \\
\text { 4) agree } \\
\text { 3) neutral }\end{array}$ & $\begin{array}{l}\text { Single answer question } \\
\text { Coded } 1 \text { through } 5 \text {, as }\end{array}$ \\
\hline
\end{tabular}




\begin{tabular}{|c|c|c|}
\hline & $\begin{array}{l}\text { 2) disagree } \\
\text { 1) strongly disagree } \\
\text { 6) I choose not to answer this } \\
\text { question }\end{array}$ & $\begin{array}{l}\text { Written } \\
\# 6=99\end{array}$ \\
\hline $\begin{array}{l}31 . \text { Eventually, science will find a } \\
\text { way to solve most human health } \\
\text { problems. }\end{array}$ & $\begin{array}{l}\text { 5) strongly agree } \\
\text { 4) agree } \\
\text { 3) neutral } \\
\text { 2) disagree } \\
\text { 1) strongly disagree } \\
\text { 6) I choose not to answer this } \\
\text { question }\end{array}$ & $\begin{array}{l}\text { Single answer question } \\
\text { Coded } 1 \text { through } 5 \text {, as } \\
\text { written } \\
\# 6=99\end{array}$ \\
\hline $\begin{array}{l}\text { 32. Government is doing a } \\
\text { competent job of protecting } \\
\text { people's health from risks related } \\
\text { to the consumption of fresh } \\
\text { vegetables. }\end{array}$ & $\begin{array}{l}\text { 5) strongly agree } \\
\text { 4) agree } \\
\text { 3) neutral } \\
\text { 2) disagree } \\
\text { 1) strongly disagree } \\
\text { 6) I choose not to answer this } \\
\text { question }\end{array}$ & $\begin{array}{l}\text { Single answer question } \\
\text { Coded } 1 \text { through } 5 \text {, as } \\
\text { written } \\
\# 6=99\end{array}$ \\
\hline $\begin{array}{l}\text { 33. I trust government to protect } \\
\text { me from risks related to the } \\
\text { consumption of fresh vegetables. }\end{array}$ & $\begin{array}{l}\text { 5) strongly agree } \\
\text { 4) agree } \\
\text { 3) neutral } \\
\text { 2) disagree } \\
\text { 1) strongly disagree } \\
\text { 6) I choose not to answer this } \\
\text { question }\end{array}$ & $\begin{array}{l}\text { Single answer question } \\
\text { Coded } 1 \text { through } 5 \text {, as } \\
\text { written } \\
\# 6=99\end{array}$ \\
\hline \multicolumn{3}{|c|}{$\begin{array}{l}\text { The following question uses a scale from } 0 \text { to } 10 \text {, where } 0 \text { means "not very likely" and } 10 \text { means } \\
\text { "very likely". }\end{array}$} \\
\hline $\begin{array}{l}\text { 34. How likely are you to get a } \\
\text { foodborne illness in the future } \\
\text { from eating fresh vegetables? }\end{array}$ & $\begin{array}{l}0=\text { not very likely } \\
10=\text { very likely } \\
99=\text { I choose not to answer this } \\
\text { question }\end{array}$ & $\begin{array}{l}\text { This will be a } \\
\text { horizontal scale } \\
\text { with } 11 \text { "radio } \\
\text { buttons"; one each } \\
\text { for one through } \\
\text { ten. Only one } \\
\text { answer possible }\end{array}$ \\
\hline \multicolumn{3}{|c|}{$\begin{array}{l}\text { The following question uses a scale from } 0 \text { to } 10 \text {, where } 0 \text { means "not very serious" and } 10 \text { means } \\
\text { "very serious". }\end{array}$} \\
\hline $\begin{array}{l}\text { 35. If you were to get a foodborne } \\
\text { illness from eating fresh } \\
\text { vegetables, how serious would this } \\
\text { illness be? }\end{array}$ & $\begin{array}{l}0=\text { not very serious } \\
10=\text { very serious } \\
99=\text { I choose not to answer this } \\
\text { question }\end{array}$ & $\begin{array}{l}\text { This will be a } \\
\text { horizontal scale } \\
\text { with } 11 \text { "radio } \\
\text { buttons"; one each } \\
\text { for one through } \\
\text { ten. Only one } \\
\text { answer possible }\end{array}$ \\
\hline
\end{tabular}




\begin{tabular}{|c|c|c|}
\hline $\begin{array}{l}\text { 36. How often do you wear a } \\
\text { seatbelt while riding in a car? }\end{array}$ & $\begin{array}{l}\text { 5)Always } \\
\text { 4)Usually } \\
\text { 3)Sometimes } \\
\text { 2)Rarely } \\
\text { 1)Never } \\
\text { 6) I choose not to answer this } \\
\text { question }\end{array}$ & $\begin{array}{l}\text { Single answer question } \\
\# 6=99\end{array}$ \\
\hline $\begin{array}{l}\text { 37. Given the choice between } \\
\text { receiving } \$ 500 \text { one month from } \\
\text { today or receiving } \$ 800 \text { one year } \\
\text { from today, which would you } \\
\text { choose? }\end{array}$ & $\begin{array}{l}\text { 1) } \$ 500 \text { one month from today } \\
\text { 2) } \$ 800 \text { one year from today } \\
\text { 3) I choose not to answer this } \\
\text { question }\end{array}$ & $\begin{array}{l}\text { Single answer question } \\
\# 3=99\end{array}$ \\
\hline \multicolumn{3}{|c|}{$\begin{array}{l}\text { For the following question, use a number from zero to ten, where zero means you have "none of this } \\
\text { feeling" and ten means you have "a lot of this feeling". }\end{array}$} \\
\hline $\begin{array}{l}38 . \text { When you think about the } \\
\text { possible health risks posed to you } \\
\text { from eating fresh vegetables, how } \\
\text { much worry do you feel? }\end{array}$ & $\begin{array}{l}0=\text { no worry } \\
10=\text { worry a lot } \\
99=\text { I choose not to answer this } \\
\text { question }\end{array}$ & $\begin{array}{l}\text { This will be a } \\
\text { horizontal scale } \\
\text { with } 11 \text { "radio } \\
\text { buttons"; one for } \\
\text { each number, zero } \\
\text { through ten. Only } \\
\text { one answer } \\
\text { possible }\end{array}$ \\
\hline $\begin{array}{l}\text { 39. When you think about the } \\
\text { possible health risks posed to your } \\
\text { clients/patients from eating fresh } \\
\text { vegetables, how much worry do } \\
\text { you feel? }\end{array}$ & $\begin{array}{l}0=\text { no worry } \\
10=\text { worry a lot } \\
99=\text { I choose not to answer this } \\
\text { question }\end{array}$ & $\begin{array}{l}\text { This will be a } \\
\text { horizontal scale } \\
\text { with } 11 \text { "radio } \\
\text { buttons"; one for } \\
\text { each number, zero } \\
\text { through ten. Only } \\
\text { one answer } \\
\text { possible }\end{array}$ \\
\hline \multicolumn{3}{|c|}{ For each of the following questions, choose the best answer: } \\
\hline $\begin{array}{l}\text { 40. If you have diarrhea, it's okay } \\
\text { to prepare food for others in the } \\
\text { family if you wash your hands } \\
\text { first. }\end{array}$ & $\begin{array}{l}\text { 1) Agree } \\
\text { 2) Disagree } \\
\text { 3) Not sure } \\
\text { 4) I choose not to answer this } \\
\text { question }\end{array}$ & $\begin{array}{l}\text { Single answer question } \\
\text { Correct answer }(\# 2)= \\
1 \\
\text { Incorrect answer }=0 \\
\text { Unsure }=0 \\
\text { Unanswered }=99\end{array}$ \\
\hline $\begin{array}{l}\text { 41. When you can't see any pink } \\
\text { color inside a cooked hamburger } \\
\text { patty you know all of the harmful } \\
\text { germs have been killed and the } \\
\text { hamburger is safe to eat. }\end{array}$ & $\begin{array}{l}\text { 1) Agree } \\
\text { 2) Disagree } \\
\text { 3) Not sure } \\
\text { 4) I choose not to answer this } \\
\text { question }\end{array}$ & $\begin{array}{l}\text { Single answer question } \\
\text { Correct answer }(\# 2)=1 \\
\text { Incorrect answer }=0 \\
\text { Unsure }=0 \\
\text { Unanswered }=99\end{array}$ \\
\hline $\begin{array}{l}\text { 42. Cooking eggs until both the } \\
\text { yolk and the white are firm will } \\
\text { kill harmful germs. }\end{array}$ & $\begin{array}{l}\text { 1) Agree } \\
\text { 2) Disagree } \\
\text { 3) Not Sure } \\
\text { 4) I choose not to answer this } \\
\text { question }\end{array}$ & $\begin{array}{l}\text { Single answer question } \\
\text { Correct answer }(\# 1)= \\
1 \\
\text { Incorrect answer }=0 \\
\text { Unsure }=0 \\
\text { Unanswered }=99\end{array}$ \\
\hline
\end{tabular}




\begin{tabular}{|c|c|c|}
\hline $\begin{array}{l}\text { 43. Using the same cutting board } \\
\text { to cut up raw chicken and then cut } \\
\text { raw vegetables for a salad is safe } \\
\text { as long as you wipe the board off } \\
\text { with a clean cloth between the } \\
\text { different foods. }\end{array}$ & $\begin{array}{l}\text { 1) Agree } \\
\text { 2) Disagree } \\
\text { 3) Not Sure } \\
\text { 4) I choose not to answer this } \\
\text { question }\end{array}$ & $\begin{array}{l}\text { Single answer question } \\
\text { Correct answer }(\# 2)= \\
1 \\
\text { Incorrect answer }=0 \\
\text { Unsure }=0 \\
\text { Unanswered }=99\end{array}$ \\
\hline $\begin{array}{l}\text { 44. If you use a dishcloth to wipe } \\
\text { up liquid from meat or chicken, } \\
\text { you can safely continue to use the } \\
\text { cloth for washing dishes if you } \\
\text { rinse the dishcloth in hot water. }\end{array}$ & $\begin{array}{l}\text { 1) Agree } \\
\text { 2) Disagree } \\
\text { 3) Not sure } \\
\text { 4) I choose not to answer this } \\
\text { question }\end{array}$ & $\begin{array}{l}\text { Single answer question } \\
\text { Correct answer }(\# 2)= \\
1 \\
\text { Incorrect answer }=0 \\
\text { Unsure }=0 \\
\text { Unanswered }=99\end{array}$ \\
\hline $\begin{array}{l}\text { 45. Head lettuce is more likely to } \\
\text { have higher microbial counts that } \\
\text { pre-washed bagged lettuce. }\end{array}$ & $\begin{array}{l}\text { 1) Agree } \\
\text { 2) Disagree } \\
\text { 3) Not sure } \\
\text { 4) I choose not to answer this } \\
\text { question }\end{array}$ & $\begin{array}{l}\text { Single answer question } \\
\text { Correct answer }(\# 2)= \\
1 \\
\text { Incorrect answer }=0 \\
\text { Unsure }=0 \\
\text { Unanswered }=99\end{array}$ \\
\hline $\begin{array}{l}\text { 46. There is less risk for bacterial } \\
\text { contamination of whole tomatoes } \\
\text { compared to pre-cut tomatoes. }\end{array}$ & $\begin{array}{l}\text { 1)Agree } \\
\text { 2)Disagree } \\
\text { 3)Not sure } \\
\text { 4) I choose not to answer this } \\
\text { question }\end{array}$ & $\begin{array}{l}\text { Single answer question } \\
\text { Correct answer }(\# 1)= \\
1 \\
\text { Incorrect answer }=0 \\
\text { Unsure }=0 \\
\text { Unanswered }=99\end{array}$ \\
\hline \multicolumn{3}{|c|}{$\begin{array}{l}\text { For the following foods, indicate whether populations who are at high risk (pregnancy, elderly, } \\
\text { infants, immunocompromised conditions) for foodborne illness should "avoid" it or if it's "okay } \\
\text { to eat". }\end{array}$} \\
\hline 47. Eggs with runny yolks & $\begin{array}{l}\text { 1) Avoid } \\
\text { 2) Okay to eat } \\
\text { 3) Not sure } \\
\text { 4) I choose not to answer this } \\
\text { question }\end{array}$ & $\begin{array}{l}\text { Single answer question } \\
\text { Correct answer }(\# 1)= \\
1 \\
\text { Incorrect answer }=0 \\
\text { Unsure }=0 \\
\text { Unanswered }=99\end{array}$ \\
\hline $\begin{array}{l}\text { 48. Raw fish or seafood like sushi, } \\
\text { sashimi, ceviche, or raw oysters }\end{array}$ & $\begin{array}{l}\text { 1) Avoid } \\
\text { 2) Okay to eat } \\
\text { 3) Not sure } \\
\text { 4) I choose not to answer this } \\
\text { question }\end{array}$ & $\begin{array}{l}\text { Single answer question } \\
\text { Correct answer }(\# 1)= \\
1 \\
\text { Incorrect answer }=0 \\
\text { Unsure }=0 \\
\text { Unanswered }=99\end{array}$ \\
\hline 49. Alfalfa or other raw sprouts & $\begin{array}{l}\text { 1) Avoid } \\
\text { 2) Okay to eat } \\
\text { 3) Not sure } \\
\text { 4) I choose not to answer this } \\
\text { question }\end{array}$ & $\begin{array}{l}\text { Single answer question } \\
\text { Correct answer }(\# 1)= \\
1 \\
\text { Incorrect answer }=0 \\
\text { Unsure }=0 \\
\text { Unanswered }=99\end{array}$ \\
\hline
\end{tabular}




\begin{tabular}{|c|c|c|}
\hline $\begin{array}{l}\text { 50. Cold (straight out of the } \\
\text { package) hot dogs }\end{array}$ & $\begin{array}{l}\text { 1)Avoid } \\
\text { 2)Okay to eat } \\
\text { 3)Not sure } \\
\text { 4) I choose not to answer this } \\
\text { question }\end{array}$ & $\begin{array}{l}\text { Single answer question } \\
\text { Correct answer }(\# 1)= \\
1 \\
\text { Incorrect answer }=0 \\
\text { Unsure }=0 \\
\text { Unanswered }=99\end{array}$ \\
\hline $\begin{array}{l}\text { 51. Soft cheese made from } \\
\text { unpasteurized milk, like Brie or } \\
\text { Camembert }\end{array}$ & $\begin{array}{l}\text { 1)Avoid } \\
\text { 2)Okay to eat } \\
\text { 3)Not sure } \\
\text { 4) I choose not to answer this } \\
\text { question }\end{array}$ & $\begin{array}{l}\text { Single answer question } \\
\text { Correct answer }(\# 1)= \\
1 \\
\text { Incorrect answer }=0 \\
\text { Unsure }=0 \\
\text { Unanswered }=99\end{array}$ \\
\hline $\begin{array}{l}\text { 52. Juices and smoothies made } \\
\text { with raw fruits and vegetables }\end{array}$ & $\begin{array}{l}\text { 1)Avoid } \\
\text { 2)Okay to eat } \\
\text { 3)Not sure } \\
\text { 4) I choose not to answer this } \\
\text { question }\end{array}$ & $\begin{array}{l}\text { Single answer question } \\
\text { Correct answer }(\# 1)= \\
1 \\
\text { Incorrect answer }=0 \\
\text { Unsure }=0 \\
\text { Unanswered }=99\end{array}$ \\
\hline $\begin{array}{l}\text { 53. A banana without washing the } \\
\text { skin first. }\end{array}$ & $\begin{array}{l}\text { 1)Avoid } \\
\text { 2)Okay to eat } \\
\text { 3)Not sure } \\
\text { 4) I choose not to answer this question }\end{array}$ & $\begin{array}{l}\text { Single answer question } \\
\text { Correct answer }(\# 2)= \\
1 \\
\text { Incorrect answer }=0 \\
\text { Unsure }=0 \\
\text { Unanswered }=99\end{array}$ \\
\hline $\begin{array}{l}\text { 54. Cut cantaloupe without } \\
\text { washing the rind first. }\end{array}$ & $\begin{array}{l}\text { 1)Avoid } \\
\text { 2)Okay to eat } \\
\text { 3)Not sure } \\
\text { 4) I choose not to answer this question }\end{array}$ & $\begin{array}{l}\text { Single answer question } \\
\text { Correct answer }(\# 1)= \\
1 \\
\text { Incorrect answer }=0 \\
\text { Unsure }=0 \\
\text { Unanswered }=99\end{array}$ \\
\hline 55. Raw unpasteurized milk & $\begin{array}{l}\text { 1)Avoid } \\
\text { 2)Okay to eat } \\
\text { 3)Not sure } \\
\text { 4) I choose not to answer this } \\
\text { question }\end{array}$ & $\begin{array}{l}\text { Single answer question } \\
\text { Correct answer }(\# 1)= \\
1 \\
\text { Incorrect answer }=0 \\
\text { Unsure }=0 \\
\text { Unanswered }=99\end{array}$ \\
\hline
\end{tabular}




\begin{tabular}{|c|c|c|}
\hline 56. Packaged baby carrots & $\begin{array}{l}\text { 1)Avoid } \\
\text { 2)Okay to eat } \\
\text { 3)Not sure } \\
\text { 4) I choose not to answer this } \\
\text { question }\end{array}$ & $\begin{array}{l}\text { Single answer question } \\
\text { Correct answer }(\# 2)= \\
1 \\
\text { Incorrect answer }=0 \\
\text { Unsure }=0 \\
\text { Unanswered }=99\end{array}$ \\
\hline \multicolumn{3}{|c|}{ For each of the following questions, choose your best answer: } \\
\hline $\begin{array}{l}57 . \text { How much have you heard } \\
\text { about the bacteria Salmonella? }\end{array}$ & $\begin{array}{l}\text { 1) Nothing } \\
\text { 2) A little } \\
\text { 3) Quite a bit } \\
\text { 4) A lot } \\
\text { 5) I choose not to answer this } \\
\text { question }\end{array}$ & $\begin{array}{l}\text { Single answer question } \\
\text { Coded as written } \\
\# 5=99\end{array}$ \\
\hline $\begin{array}{l}\text { 58. How would you rate your } \\
\text { understanding of the bacteria } \\
\text { Salmonella? }\end{array}$ & $\begin{array}{l}\text { 1) Very low } \\
\text { 2) Low } \\
\text { 3) Moderate } \\
\text { 4) High } \\
\text { 5) Very high } \\
\text { 6) I choose not to answer this } \\
\text { question }\end{array}$ & $\begin{array}{l}\text { Single answer question } \\
\text { Coded as written } \\
\# 6=99\end{array}$ \\
\hline $\begin{array}{l}59 . \text { How much have you heard } \\
\text { about the bacteria } E \text { coli O157:H7? }\end{array}$ & $\begin{array}{l}\text { 1) Nothing } \\
\text { 2) A little } \\
\text { 3) Quite a bit } \\
\text { 4) A lot } \\
\text { 5) I choose not to answer this } \\
\text { question }\end{array}$ & $\begin{array}{l}\text { Single answer question } \\
\text { Coded as written } \\
\# 5=99\end{array}$ \\
\hline $\begin{array}{l}\text { 60. How would you rate your } \\
\text { understanding of the bacteria } E \\
\text { coli O157:H7? }\end{array}$ & $\begin{array}{l}\text { 1) Very low } \\
\text { 2) Low } \\
\text { 3) Moderate } \\
\text { 4) High } \\
\text { 5) Very high } \\
\text { 6) I choose not to answer this } \\
\text { question }\end{array}$ & $\begin{array}{l}\text { Single answer question } \\
\text { Coded as written } \\
\# 6=99\end{array}$ \\
\hline $\begin{array}{l}\text { 61. How much have you heard } \\
\text { about the bacteria Campylobactor } \\
\text { jejuni? }\end{array}$ & $\begin{array}{l}\text { 1) Nothing } \\
\text { 2) A little } \\
\text { 3) Quite a bit } \\
\text { 4) A lot } \\
\text { 5) I choose not to answer this } \\
\text { question. } \\
\end{array}$ & $\begin{array}{l}\text { Single answer question } \\
\text { Coded as written } \\
\# 5=99\end{array}$ \\
\hline $\begin{array}{l}\text { 62. How would you rate your } \\
\text { understanding of the bacteria } \\
\text { Campylobactor jejuni? }\end{array}$ & $\begin{array}{ll}\text { 1) } & \text { Very low } \\
\text { 2) Low } \\
\text { 3) Moderate } \\
\text { 4) High } \\
\text { 5) Very high } \\
\text { 6) I choose not to answer this } \\
\text { question } \\
\end{array}$ & $\begin{array}{l}\text { Single answer question } \\
\text { Coded as written } \\
\# 6=99\end{array}$ \\
\hline $\begin{array}{l}\text { 63. How much have you heard } \\
\text { about the bacteria Listeria } \\
\text { monocytogenes? }\end{array}$ & $\begin{array}{l}\text { 1) Nothing } \\
\text { 2) A little } \\
\text { 3) Quite a bit } \\
\text { 4) A lot } \\
\text { 5)I choose not to answer this }\end{array}$ & $\begin{array}{l}\text { Single answer question } \\
\text { Coded as written } \\
\# 5=99\end{array}$ \\
\hline
\end{tabular}




\begin{tabular}{|c|c|c|}
\hline & question. & \\
\hline $\begin{array}{l}\text { 64. How would you rate your } \\
\text { understanding of the bacteria } \\
\text { Listeria Monocytogenes? }\end{array}$ & $\begin{array}{l}\text { 1) Very low } \\
\text { 2) Low } \\
\text { 3) Moderate } \\
\text { 4) High } \\
\text { 5) Very high } \\
\text { 6)I choose not to answer this } \\
\text { question }\end{array}$ & $\begin{array}{l}\text { Single answer question } \\
\text { Coded as written } \\
\# 6=99\end{array}$ \\
\hline \multicolumn{3}{|c|}{$\begin{array}{l}\text { Read each of the following statements. Mark the box that is the closest match to your own } \\
\text { opinion. }\end{array}$} \\
\hline $\begin{array}{l}\text { 65. If I wanted to, I could easily } \\
\text { get all the information I need about } \\
\text { the food safety of fresh vegetables. }\end{array}$ & $\begin{array}{l}\text { 5)Strongly agree } \\
\text { 4)Agree } \\
\text { 3)Neutral } \\
\text { 2)Disagree } \\
\text { 1) Strongly disagree } \\
\text { 6) I choose not to answer this } \\
\text { question }\end{array}$ & $\begin{array}{l}\text { Single answer question } \\
\text { Coded as written } \\
\# 6=99\end{array}$ \\
\hline $\begin{array}{l}\text { 66. It is hard for me to get useful } \\
\text { information about the food safety } \\
\text { of fresh vegetables }\end{array}$ & $\begin{array}{l}\text { 1)Strongly agree } \\
\text { 2)Agree } \\
\text { 3)Neutral } \\
\text { 4)Disagree } \\
\text { 5)Strongly disagree } \\
\text { 6) I choose not to answer this } \\
\text { question }\end{array}$ & $\begin{array}{l}\text { Single answer question } \\
\text { Coded as written } \\
\# 6=99\end{array}$ \\
\hline $\begin{array}{l}\text { 67. The media often exaggerate } \\
\text { and sensationalize the news. }\end{array}$ & $\begin{array}{l}\text { 5)Strongly agree } \\
\text { 4)Agree } \\
\text { 3)Neutral } \\
\text { 2)Disagree } \\
\text { 1) Strongly disagree } \\
\text { 6) I choose not to answer this } \\
\text { question }\end{array}$ & $\begin{array}{l}\text { Single answer question } \\
\text { Coded as written } \\
\# 6=99\end{array}$ \\
\hline $\begin{array}{l}\text { 68. News media often represent } \\
\text { their own bias and interest. }\end{array}$ & $\begin{array}{l}\text { 5)Strongly agree } \\
\text { 4)Agree } \\
\text { 3)Neutral } \\
\text { 2)Disagree } \\
\text { 1)Strongly disagree } \\
\text { 6) I choose not to answer this } \\
\text { question }\end{array}$ & $\begin{array}{l}\text { Single answer question } \\
\text { Coded as written } \\
\# 6=99\end{array}$ \\
\hline $\begin{array}{l}\text { 69. News stories are just a series of } \\
\text { unconnected events that don't add } \\
\text { up to much. }\end{array}$ & $\begin{array}{l}\text { 5)Strongly agree } \\
\text { 4)Agree } \\
\text { 3)Neutral } \\
\text { 2)Disagree } \\
\text { 1)Strongly disagree } \\
\text { 6) I choose not to answer this } \\
\text { question }\end{array}$ & $\begin{array}{l}\text { Single answer question } \\
\text { Coded as written } \\
\# 6=99\end{array}$ \\
\hline $\begin{array}{l}\text { 70. When the same information } \\
\text { appears in many places, I'm more } \\
\text { likely to believe it. }\end{array}$ & $\begin{array}{l}\text { 5)Strongly agree } \\
\text { 4)Agree } \\
\text { 3)Neutral } \\
\text { 2)Disagree } \\
\text { 1)Strongly disagree } \\
\text { 6) I choose not to answer this } \\
\text { question }\end{array}$ & $\begin{array}{l}\text { Single answer question } \\
\text { Coded as written } \\
\# 6=99\end{array}$ \\
\hline 71. News stories with statistics are & 5)Strongly agree & Single answer question \\
\hline
\end{tabular}




\begin{tabular}{|c|c|c|}
\hline $\begin{array}{l}\text { more believable than those } \\
\text { without. }\end{array}$ & $\begin{array}{l}\text { 4)Agree } \\
\text { 3)Neutral } \\
\text { 2)Disagree } \\
\text { 1)Strongly disagree } \\
\text { 6) I choose not to answer } \\
\text { this question }\end{array}$ & $\begin{array}{l}\text { Coded as written } \\
\# 6=99\end{array}$ \\
\hline $\begin{array}{l}\text { 72. Individual news stories may } \\
\text { seem like bits and pieces, but in } \\
\text { the long run they form a } \\
\text { meaningful pattern. }\end{array}$ & $\begin{array}{l}\text { 5)Strongly agree } \\
\text { 4)Agree } \\
\text { 3)Neutral } \\
\text { 2)Disagree } \\
\text { 1)Strongly disagree } \\
\text { 6) I choose not to answer this } \\
\text { question }\end{array}$ & $\begin{array}{l}\text { Single answer question } \\
\text { Coded as written } \\
\# 6=99\end{array}$ \\
\hline \multicolumn{2}{|c|}{$\begin{array}{l}\text { On a scale of } 0 \text { to } 10 \text {, where } 0 \text { is "none" and } 10 \text { is "a lot", how much } \\
\text { attention do you pay to the following: }\end{array}$} & $\begin{array}{l}\text { These will be } \\
\text { horizontal scales with } \\
10 \text { "radio buttons"; one } \\
\text { each for one through } \\
\text { ten. Only one answer } \\
\text { possible }\end{array}$ \\
\hline $\begin{array}{l}\text { 73. TV news stories about the food } \\
\text { safety of fresh vegetables? }\end{array}$ & $\begin{array}{l}0=\text { none } \\
10=\text { a lot } \\
99=\text { I choose not to answer this } \\
\text { question }\end{array}$ & Single answer question \\
\hline $\begin{array}{l}\text { 74. Newspaper stories about food } \\
\text { safety of fresh vegetables? }\end{array}$ & $\begin{array}{l}0=\text { none } \\
10=\text { a lot } \\
99=I \text { choose not to answer this } \\
\text { question }\end{array}$ & Single answer question \\
\hline $\begin{array}{l}\text { 75. Discussions among friends, } \\
\text { coworkers, or family that turn to } \\
\text { the food safety of fresh vegetables? }\end{array}$ & $\begin{array}{l}0=\text { none } \\
10=\text { a lot } \\
99=I \text { choose not to answer this } \\
\text { question }\end{array}$ & Single answer question \\
\hline $\begin{array}{l}\text { 76. Information on the radio about } \\
\text { the food safety of fresh vegetables? }\end{array}$ & $\begin{array}{l}0=\text { none } \\
10=\text { a lot } \\
99=\text { I choose not to answer this } \\
\text { question }\end{array}$ & \\
\hline \multicolumn{3}{|c|}{ For each of the following questions, provide your best answer: } \\
\hline $\begin{array}{l}\text { 77. Where, if at all, do you } \\
\text { currently get your information on } \\
\text { food safety? (Check all that } \\
\text { apply.) }\end{array}$ & $\begin{array}{l}\text { 1) } \begin{array}{l}\text { I do not seek out food } \\
\text { safety information }\end{array} \\
\text { 2) } \begin{array}{l}\text { Print materials } \\
\text { (magazines, } \\
\text { newspapers, brochures, } \\
\text { etc) }\end{array} \\
\text { 3) Professional } \\
\text { curriculums/textbooks } \\
\text { 4) Professional journals } \\
\text { 5) Professional trainings } \\
\text { (seminars and/or } \\
\text { workshops) } \\
\text { Websites: } \\
\text { 7) Media (TV, }\end{array}$ & $\begin{array}{l}\text { Multiple } \\
\text { answers } \\
\text { possible. } \\
\text { Use text } \\
\text { boxes for } \\
\text { numbers } \\
\text { three five } \\
\text { and eight }\end{array}$ \\
\hline
\end{tabular}




\begin{tabular}{|c|c|c|}
\hline & $\begin{array}{ll} & \text { Newspaper, etc.) } \\
\text { 8) } & \text { Friends/family (non } \\
& \text { health professional) } \\
\text { 9) } & \text { Friends/family (health } \\
\text { professional) } \\
\text { 10) } \\
\text { 11 don't remember } \\
\text { Other (please } \\
\text { specifically describe. } \\
\text { Please do not include } \\
\text { quotes [" "] or } \\
\text { apostrophes ['] as part } \\
\text { of your response } \\
\text { 99) I choose not to answer } \\
\text { this question }\end{array}$ & \\
\hline $\begin{array}{l}\text { 78. Name up to three } \\
\text { professional journals that } \\
\text { you read for food safety } \\
\text { information. Please do not } \\
\text { include quotes [" "] or } \\
\text { apostrophes ['] as part of } \\
\text { your response. }\end{array}$ & Blank & \\
\hline $\begin{array}{l}\text { 79. Name up to three } \\
\text { websites that you view for } \\
\text { food safety information. } \\
\text { Please do not include quotes } \\
\text { [" "] or apostrophes ['] as } \\
\text { part of your response. }\end{array}$ & Blank & \\
\hline $\begin{array}{l}80 . \text { Have you ever received any } \\
\text { specific training on food safety? }\end{array}$ & $\begin{array}{l}\text { 1) Yes } \\
\text { 2) No } \\
\text { 3) I choose not to answer } \\
\text { this question }\end{array}$ & $\begin{array}{l}\text { Single answer question } \\
\text { Coded as written } \\
\# 3=99 \\
\text { If yes then go to next } \\
\text { question, if no, skip } \\
\text { next question and go to } \\
\text { question number } 82 .\end{array}$ \\
\hline
\end{tabular}




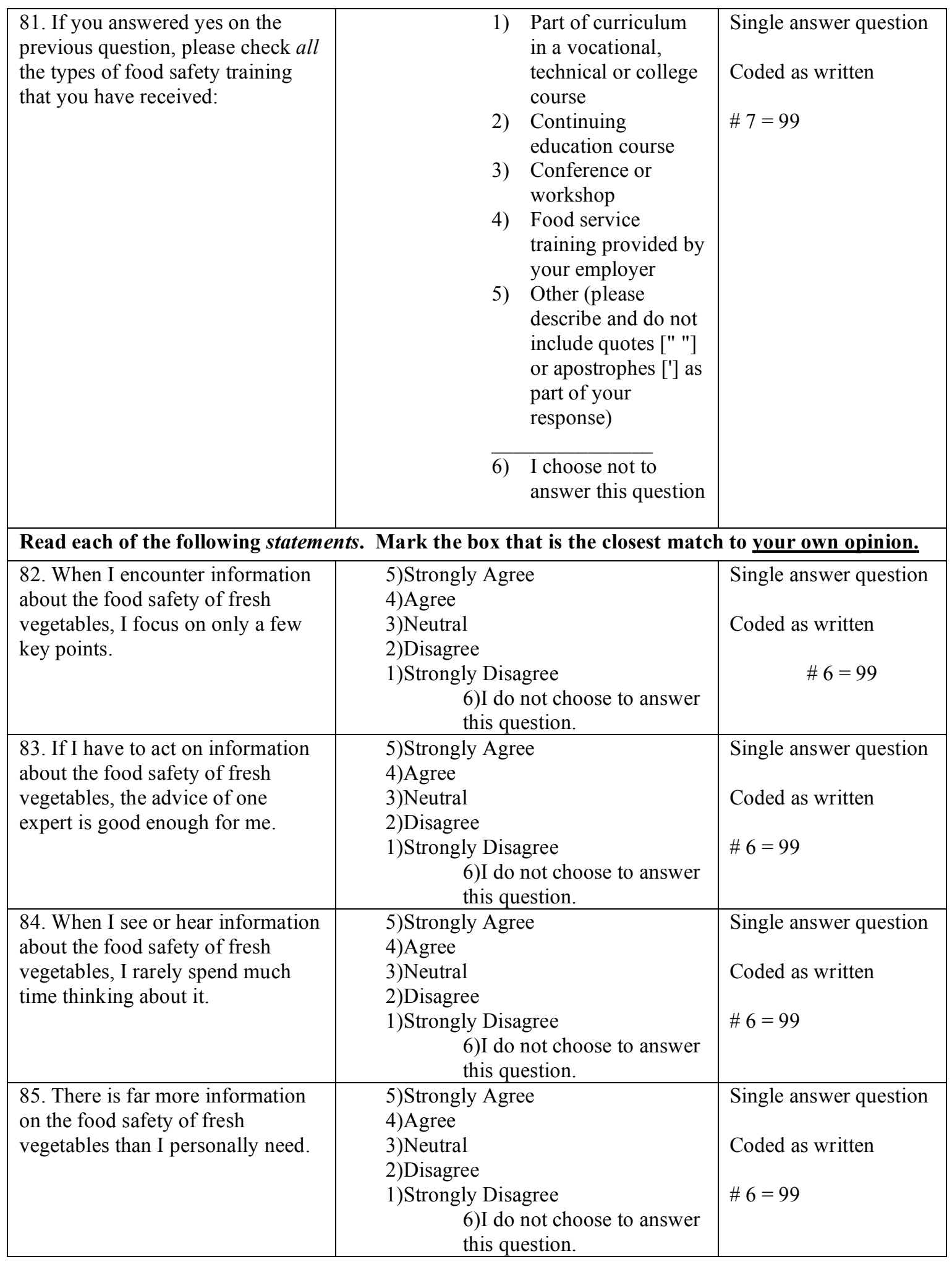




\begin{tabular}{|c|c|c|}
\hline $\begin{array}{l}\text { 86. After I encounter information } \\
\text { about the food safety of fresh } \\
\text { vegetables, I am likely to stop and } \\
\text { think about it. }\end{array}$ & $\begin{array}{l}\text { 5)Strongly Agree } \\
\text { 4)Agree } \\
\text { 3)Neutral } \\
\text { 2)Disagree } \\
\text { 1)Strongly Disagree } \\
\quad \text { 6)I do not choose to answer } \\
\quad \text { this question. }\end{array}$ & $\begin{array}{l}\text { Single answer question } \\
\text { Coded as written } \\
\# 6=99\end{array}$ \\
\hline $\begin{array}{l}\text { 87. If I need to act on information } \\
\text { about the food safety of fresh } \\
\text { vegetables, the more viewpoints I } \\
\text { get the better. }\end{array}$ & $\begin{array}{l}\text { 5)Strongly Agree } \\
\text { 4)Agree } \\
\text { 3)Neutral } \\
\text { 2)Disagree } \\
\text { 1)Strongly Disagree } \\
\text { 6)I do not choose to answer } \\
\quad \text { this question. }\end{array}$ & $\begin{array}{l}\text { Single answer question } \\
\text { Coded as written } \\
\# 6=99\end{array}$ \\
\hline $\begin{array}{l}\text { 88. It is important for me to } \\
\text { interpret information about the } \\
\text { food safety of fresh vegetables in a } \\
\text { way that applies directly to my } \\
\text { life. }\end{array}$ & $\begin{array}{l}\text { 5)Strongly Agree } \\
\text { 4)Agree } \\
\text { 3)Neutral } \\
\text { 2)Disagree } \\
\text { 1)Strongly Disagree } \\
\text { 6)I do not choose to answer this question. }\end{array}$ & $\begin{array}{l}\text { Single answer question } \\
\text { Coded as written } \\
\# 6=99\end{array}$ \\
\hline $\begin{array}{l}\text { 89. When I encounter information } \\
\text { about the food safety of fresh } \\
\text { vegetables, I read or listen to most } \\
\text { of it, even though I may not agree } \\
\text { with the perspective. }\end{array}$ & $\begin{array}{l}\text { 5)Strongly Agree } \\
\text { 4)Agree } \\
\text { 3)Neutral } \\
\text { 2)Disagree } \\
\text { 1)Strongly Disagree } \\
\text { 6)I do not choose to answer this question. }\end{array}$ & $\begin{array}{l}\text { Single answer question } \\
\text { Coded as written } \\
\# 6=99\end{array}$ \\
\hline \multicolumn{3}{|c|}{$\begin{array}{l}\text { Read each of the following statements and mark the box that is the closest match to your own } \\
\text { opinion. } \\
\text { When I educate my clients/patients on fresh vegetables (not food safety, just fresh vegetables in } \\
\text { general) I take the opportunity to highlight the importance of: }\end{array}$} \\
\hline $\begin{array}{l}\text { 90. Fresh vegetable total } \\
\text { nutritional content. }\end{array}$ & $\begin{array}{l}\text { 2)Very likely } \\
\text { 1)Likely } \\
\text { 0)Neutral } \\
\text {-2)Unlikely } \\
\text {-1)Very unlikely } \\
\text { 6)I choose not to answer this } \\
\text { question. }\end{array}$ & $\begin{array}{l}\text { Single answer question } \\
\text { Coded as written } \\
\# 6=99\end{array}$ \\
\hline $\begin{array}{l}\text { 91. Fresh vegetable dietary fiber } \\
\text { content. }\end{array}$ & $\begin{array}{l}\text { 2)Very likely } \\
\text { 1)Likely } \\
\text { 0)Neutral } \\
\text {-2)Unlikely } \\
\text {-1)Very unlikely } \\
\text { 6)I choose not to answer this } \\
\text { question. }\end{array}$ & $\begin{array}{l}\text { Single answer question } \\
\text { Coded as written } \\
\# 6=99\end{array}$ \\
\hline $\begin{array}{l}\text { 92. Fresh vegetable vitamin } \\
\text { content. }\end{array}$ & $\begin{array}{l}\text { 2)Very likely } \\
\text { 1)Likely } \\
\text { 0)Neutral } \\
\text {-2)Unlikely } \\
\text {-1)Very unlikely } \\
\text { 6)I choose not to answer this } \\
\text { question. }\end{array}$ & $\begin{array}{l}\text { Single answer question } \\
\text { Coded as written } \\
\# 6=99\end{array}$ \\
\hline
\end{tabular}




\begin{tabular}{|c|c|c|}
\hline $\begin{array}{l}\text { 93. Choosing easily prepared fresh } \\
\text { vegetables. }\end{array}$ & $\begin{array}{l}\text { 2)Very likely } \\
\text { 1)Likely } \\
\text { 0)Neutral } \\
\text {-2)Unlikely } \\
\text {-1)Very unlikely } \\
\text { 6)I choose not to answer this } \\
\text { question. }\end{array}$ & $\begin{array}{l}\text { Single answer question } \\
\text { Coded as written } \\
\# 6=99\end{array}$ \\
\hline $\begin{array}{l}\text { 94. Considering the cost of fresh } \\
\text { vegetables. }\end{array}$ & $\begin{array}{l}\text { 2)Very likely } \\
\text { 1)Likely } \\
\text { 0)Neutral } \\
\text {-2)Unlikely } \\
\text {-1)Very unlikely } \\
\text { 6)I choose not to answer this } \\
\text { question. }\end{array}$ & $\begin{array}{l}\text { Single answer question } \\
\text { Coded as written } \\
\# 6=99\end{array}$ \\
\hline $\begin{array}{l}\text { 95. Choosing the least likely } \\
\text { contaminated fresh vegetables. }\end{array}$ & $\begin{array}{l}\text { 2)Very likely } \\
\text { 1)Likely } \\
\text { 0)Neutral } \\
\text {-2)Unlikely } \\
\text {-1)Very unlikely } \\
\text { 6)I choose not to answer this } \\
\text { question. }\end{array}$ & $\begin{array}{l}\text { Single answer question } \\
\text { Coded as written } \\
\# 6=99\end{array}$ \\
\hline $\begin{array}{l}\text { 96. Considering the shelf-life of } \\
\text { the fresh vegetable. }\end{array}$ & $\begin{array}{l}\text { 5)Very likely } \\
\text { 4)Likely } \\
\text { 3)Neutral } \\
\text { 2)Unlikely } \\
\text { 1)Very unlikely } \\
\text { 6)I choose not to answer this } \\
\text { question. }\end{array}$ & $\begin{array}{l}\text { Single answer question } \\
\text { Coded as written } \\
\# 6=99\end{array}$ \\
\hline $\begin{array}{l}\text { 97. The origin of the fresh } \\
\text { vegetable (local vs. non-local). }\end{array}$ & $\begin{array}{l}\text { 2)Very likely } \\
\text { 1)Likely } \\
\text { 0)Neutral } \\
\text {-2)Unlikely } \\
\text {-1)Very unlikely } \\
\text { 6)I choose not to answer this } \\
\text { question. }\end{array}$ & $\begin{array}{l}\text { Single answer question } \\
\text { Coded as written } \\
\# 6=99\end{array}$ \\
\hline $\begin{array}{l}\text { 98. Whether the fresh vegetable is } \\
\text { organic or non-organic. }\end{array}$ & $\begin{array}{l}\text { 2)Very likely } \\
\text { 1)Likely } \\
\text { 0)Neutral } \\
\text {-2)Unlikely } \\
\text {-1)Very unlikely } \\
\text { 6)I choose not to answer this } \\
\text { question. }\end{array}$ & $\begin{array}{l}\text { Single answer question } \\
\text { Coded as written } \\
\# 6=99\end{array}$ \\
\hline $\begin{array}{l}\text { 99. Whether the fresh vegetable } \\
\text { has been highly publicized } \\
\text { regarding recent outbreaks of } \\
\text { foodborne illness. }\end{array}$ & $\begin{array}{l}\text { 2)Very likely } \\
\text { 1)Likely } \\
\text { 0)Neutral } \\
\text {-2)Unlikely }\end{array}$ & $\begin{array}{l}\text { Single answer question } \\
\text { Coded as written }\end{array}$ \\
\hline
\end{tabular}




\begin{tabular}{|c|c|c|}
\hline & $\begin{array}{l}\text {-1)Very unlikely } \\
\text { 6)I choose not to answer this } \\
\text { question. }\end{array}$ & $\# 6=99$ \\
\hline \multicolumn{3}{|c|}{$\begin{array}{l}\text { Read each of the following statements. Mark the box that is the closest match to your own opinion. } \\
\text { Indicate whether you think the following is important or unimportant, as pertaining to fresh vegetables. }\end{array}$} \\
\hline 100. Total nutrition & $\begin{array}{l}\text { +2)Completely important } \\
\text { +1)Important } \\
\text { 0)Neutral } \\
\text {-1)Unimportant } \\
\text {-2)Completely unimportant } \\
\text { 6)I choose not to answer this } \\
\text { question. }\end{array}$ & $\begin{array}{l}\text { Single answer question } \\
\text { Coded as written } \\
\# 6=99\end{array}$ \\
\hline 101. Dietary fiber & $\begin{array}{l}\text { +2)Completely important } \\
\text { +1)Important } \\
\text { 0)Neutral } \\
\text {-1)Unimportant } \\
\text {-2)Completely unimportant } \\
\text { 6)I choose not to answer this } \\
\text { question. }\end{array}$ & $\begin{array}{l}\text { Single answer question } \\
\text { Coded as written } \\
\# 6=99\end{array}$ \\
\hline 102. Vitamins & $\begin{array}{l}\text { +2)Completely important } \\
\text { +1)Important } \\
\text { 0)Neutral } \\
\text {-1)Unimportant } \\
\text {-2)Completely unimportant } \\
\text { 6)I choose not to answer this } \\
\text { question. }\end{array}$ & $\begin{array}{l}\text { Single answer question } \\
\text { Coded as written } \\
\# 6=99\end{array}$ \\
\hline $\begin{array}{l}\text { 103. Choosing a vegetable that is } \\
\text { easy to prepare. }\end{array}$ & $\begin{array}{l}\text { +2)Completely important } \\
\text { +1)Important } \\
\text { 0)Neutral } \\
\text {-1)Unimportant } \\
\text {-2)Completely unimportant } \\
\text { 6)I choose not to answer this } \\
\text { question. }\end{array}$ & $\begin{array}{l}\text { Single answer question } \\
\text { Coded as written } \\
\# 6=99\end{array}$ \\
\hline $\begin{array}{l}\text { 104. Choosing a fresh vegetable } \\
\text { that is low in cost. }\end{array}$ & $\begin{array}{l}\text { +2)Completely important } \\
\text { +1)Important } \\
\text { 0)Neutral } \\
\text {-1)Unimportant } \\
\text {-2)Completely unimportant } \\
\text { 6)I choose not to answer this } \\
\text { question. }\end{array}$ & $\begin{array}{l}\text { Single answer question } \\
\text { Coded as written } \\
\# 6=99\end{array}$ \\
\hline $\begin{array}{l}\text { 105. Avoiding fresh vegetables } \\
\text { that can be contaminated with } \\
\text { pathogens such as E.coli or } \\
\text { Salmonella. }\end{array}$ & $\begin{array}{l}\text { +2)Completely important } \\
\text { +1)Important } \\
\text { 0)Neutral }\end{array}$ & $\begin{array}{l}\text { Single answer question } \\
\text { Coded as written }\end{array}$ \\
\hline
\end{tabular}




\begin{tabular}{|c|c|c|c|}
\hline & \multicolumn{2}{|c|}{$\begin{array}{l}\text {-1)Unimportant } \\
\text {-2)Completely unimportant } \\
\text { 6)I choose not to answer this } \\
\text { question. }\end{array}$} & $\# 6=99$ \\
\hline $\begin{array}{l}\text { 106. Choosing a fresh vegetable } \\
\text { with a longer shelf-life. }\end{array}$ & \multicolumn{2}{|c|}{$\begin{array}{l}\text { +2)Completely important } \\
\text { +1)Important } \\
\text { 0)Neutral } \\
\text {-1)Unimportant } \\
\text {-2)Completely unimportant } \\
\text { choose not to answer this } \\
\text { estion. }\end{array}$} & $\begin{array}{l}\text { Single answer question } \\
\text { Coded as written } \\
\# 6=99\end{array}$ \\
\hline $\begin{array}{l}\text { 107. Choosing only locally grown } \\
\text { fresh vegetables. }\end{array}$ & \multicolumn{2}{|c|}{$\begin{array}{l}\text { +2)Completely important } \\
\text { +1)Important } \\
\text { 0)Neutral } \\
\text {-1)Unimportant } \\
\text {-2)Completely unimportant } \\
\text { choose not to answer this } \\
\text { estion. }\end{array}$} & $\begin{array}{l}\text { Single answer question } \\
\text { Coded as written } \\
\# 6=99\end{array}$ \\
\hline $\begin{array}{l}\text { 108. Choosing only organic fresh } \\
\text { vegetables. }\end{array}$ & \multicolumn{2}{|c|}{$\begin{array}{l}\text { +2)Completely important } \\
\text { +1)Important } \\
\text { 0)Neutral } \\
\text {-1)Unimportant } \\
\text {-2)Completely unimportant } \\
\text { I choose not to answer this } \\
\text { estion.. }\end{array}$} & $\begin{array}{l}\text { Single answer question } \\
\text { Coded as written } \\
\# 6=99\end{array}$ \\
\hline $\begin{array}{l}\text { 109. Staying away from fresh } \\
\text { vegetables that have been highly } \\
\text { publicized regarding any } \\
\text { foodborne illness outbreak. }\end{array}$ & \multicolumn{2}{|l|}{$\begin{array}{l}\text { +2)Completely important } \\
\text { +1)Important } \\
\text { 0)Neutral } \\
\text {-1)Unimportant } \\
\text {-2)Completely unimportant } \\
\text { 6)I choose not to answer this } \\
\text { question.. }\end{array}$} & $\begin{array}{l}\text { Single answer question } \\
\text { Coded as written } \\
\# 6=99\end{array}$ \\
\hline \multicolumn{4}{|c|}{$\begin{array}{l}\text { Read each of the following statements. Mark the box that is the closest match to your own opinion. } \\
\text { Carrying out education of fresh vegetable FOOD SAFETY to my clients/patients means: }\end{array}$} \\
\hline $\begin{array}{l}\text { 110. Less foodborne illness } \\
\text { among my clients/patients. }\end{array}$ & $\begin{array}{l}\text { 2)Very likely } \\
\text { 1)Likely } \\
\text { 0)Neutral } \\
\text {-1)Unlikely } \\
\text {-2)Very unlikely } \\
\text { 6)I choose not to answer this } \\
\text { question. }\end{array}$ & & $\begin{array}{l}\text { iswer question } \\
\text { written }\end{array}$ \\
\hline $\begin{array}{l}\text { 111. Less time for me to teach } \\
\text { other things to my } \\
\text { clients/patients. }\end{array}$ & $\begin{array}{l}\text {-2)Very likely } \\
\text {-1)Likely } \\
\text { 0)Neutral } \\
\text { 1)Unlikely } \\
\text { 2)Very unlikely } \\
\text { 6)I choose not to answer this }\end{array}$ & & $\begin{array}{l}\text { iswer question } \\
\text { written }\end{array}$ \\
\hline
\end{tabular}




\begin{tabular}{|c|c|c|}
\hline & question. & \\
\hline 112. Thankful clients/patients. & $\begin{array}{l}\text { 2)Very likely } \\
\text { 1)Likely } \\
\text { 0)Neutral } \\
\text {-1)Unlikely } \\
\text {-2)Very unlikely } \\
\text { 6)I choose not to answer this } \\
\text { question. }\end{array}$ & $\begin{array}{l}\text { Single answer question } \\
\text { Coded as written } \\
\# 6=99\end{array}$ \\
\hline $\begin{array}{l}\text { 113. Achieving a good reputation } \\
\text { as a registered dietitian. }\end{array}$ & $\begin{array}{l}\text { 2)Very likely } \\
\text { 1)Likely } \\
\text { 0)Neutral } \\
\text {-1)Unlikely } \\
\text {-2)Very unlikely } \\
\text { 6)I choose not to answer this } \\
\text { question. }\end{array}$ & $\begin{array}{l}\text { Single answer question } \\
\text { Coded as written } \\
\# 6=99\end{array}$ \\
\hline $\begin{array}{l}\text { 114. More local community } \\
\text { awareness of foodborne illness } \\
\text { from fresh vegetables. }\end{array}$ & $\begin{array}{l}\text { 2)Very likely } \\
\text { 1)Likely } \\
\text { 0)Neutral } \\
\text {-1)Unlikely } \\
\text {-2)Very unlikely } \\
\text { 6)I choose not to answer this } \\
\text { question. }\end{array}$ & $\begin{array}{l}\text { Single answer question } \\
\text { Coded as written } \\
\# 6=99\end{array}$ \\
\hline $\begin{array}{l}\text { 115. My clients/patients will } \\
\text { purchase fewer fresh vegetables } \\
\text { and instead will purchase canned } \\
\text { and/or frozen vegetables. }\end{array}$ & $\begin{array}{l}\text {-2)Very likely } \\
\text {-1)Likely } \\
\text { 0)Neutral } \\
\text { 1)Unlikely } \\
\text { 2)Very unlikely } \\
\text { 6)I choose not to answer this } \\
\text { question. }\end{array}$ & $\begin{array}{l}\text { Single answer question } \\
\text { Coded as written } \\
\# 6=99\end{array}$ \\
\hline $\begin{array}{l}\text { 116. My clients/patients will not } \\
\text { listen. }\end{array}$ & $\begin{array}{l}\text {-2)Very likely } \\
\text {-1)Likely } \\
\text { 0)Neutral } \\
\text { 1)Unlikely } \\
\text { 2)Very unlikely } \\
\text { 6)I choose not to answer this } \\
\text { question. }\end{array}$ & $\begin{array}{l}\text { Single answer question } \\
\text { Coded as written } \\
\# 6=99\end{array}$ \\
\hline $\begin{array}{l}\text { 117. My clients/patients will } \\
\text { become more interested in fruits } \\
\text { instead of fresh vegetables. }\end{array}$ & $\begin{array}{l}\text {-2)Very likely } \\
\text {-1)Likely } \\
\text { 0)Neutral } \\
\text { 1)Unlikely } \\
\text { 2)Very unlikely } \\
\text { 6)I choose not to answer this } \\
\text { question. }\end{array}$ & $\begin{array}{l}\text { Single answer question } \\
\text { Coded as written } \\
\# 6=99\end{array}$ \\
\hline $\begin{array}{l}\text { 118. My clients/patients will } \\
\text { purchase more locally grown } \\
\text { fresh vegetables. }\end{array}$ & $\begin{array}{l}\text { 2)Very likely } \\
\text { 1)Likely } \\
\text { 0)Neutral }\end{array}$ & $\begin{array}{l}\text { Single answer question } \\
\text { Coded as written }\end{array}$ \\
\hline
\end{tabular}




\begin{tabular}{|c|c|c|}
\hline & $\begin{array}{l}\text {-1)Unlikely } \\
\text {-2)Very unlikely } \\
\text { 6)I choose not to answer this } \\
\text { question. }\end{array}$ & $\# 6=99$ \\
\hline $\begin{array}{l}\text { 119. My clients/patients will } \\
\text { purchase more organic fresh } \\
\text { vegetables. }\end{array}$ & $\begin{array}{l}\text { 2)Very likely } \\
\text { 1)Likely } \\
\text { 0)Neutral } \\
\text {-1)Unlikely } \\
\text {-2)Very unlikely } \\
\text { 6)I choose not to answer this } \\
\text { question. }\end{array}$ & $\begin{array}{l}\text { Single answer question } \\
\text { Coded as written } \\
\# 6=99\end{array}$ \\
\hline \multicolumn{3}{|c|}{$\begin{array}{l}\text { Read each of the following statements. Mark the box that is the closest match to your own opinion. } \\
\text { Carrying out education of fresh vegetable FOOD SAFETY to my clients/patients is: }\end{array}$} \\
\hline $\begin{array}{l}\text { 120. Something that only } \\
\text { registered dietitians should do. }\end{array}$ & $\begin{array}{l}\text { 2)Very likely } \\
\text { 1)Likely } \\
\text { 0)Neutral } \\
\text {-1)Unlikely } \\
\text {-2)Very unlikely } \\
\text { 6)I choose not to answer this } \\
\text { question. }\end{array}$ & $\begin{array}{l}\text { Single answer question } \\
\text { Coded as written } \\
\# 6=99\end{array}$ \\
\hline $\begin{array}{l}\text { 121. Pointless and unnecessary, } \\
\text { according to my personal beliefs. }\end{array}$ & $\begin{array}{l}\text {-2)Very likely } \\
\text { 11)Likely } \\
\text { 0)Neutral } \\
\text { 1)Unlikely } \\
\text { 2)Very unlikely } \\
\text { 6)I choose not to answer this } \\
\text { question. }\end{array}$ & $\begin{array}{l}\text { Single answer question } \\
\text { Coded as written } \\
\# 6=99\end{array}$ \\
\hline $\begin{array}{l}\text { 122. Necessary if the } \\
\text { client/patient is in a high-risk } \\
\text { population (eg. Elderly, children, } \\
\text { immunocompromised) }\end{array}$ & $\begin{array}{l}\text { 2)Very likely } \\
\text { 1)Likely } \\
\text { 0)Neutral } \\
\text {-1)Unlikely } \\
\text {-2)Very unlikely } \\
\text { 6)I choose not to answer this } \\
\text { question. }\end{array}$ & $\begin{array}{l}\text { Single answer question } \\
\text { Coded as written } \\
\# 6=99\end{array}$ \\
\hline \multicolumn{3}{|c|}{ Read each of the following statements. Mark the box that is the closest match to your own opinion. } \\
\hline $\begin{array}{l}\text { 123. Less food poisoning among } \\
\text { my clients is: }\end{array}$ & $\begin{array}{l}\text { +2)Completely } \\
\text { important } \\
+1 \text { )Important } \\
\text { 0)Neutral } \\
\text {-1)Unimportant } \\
\text {-2)Completely } \\
\text { unimportant } \\
\text { 6)I choose not to answer this } \\
\text { question. }\end{array}$ & \\
\hline $\begin{array}{l}\text { 124. Having enough time to } \\
\text { teach the things I want to teach } \\
\text { is: }\end{array}$ & $\begin{array}{l}+2) \text { Completely } \\
\text { important }\end{array}$ & $\begin{array}{l}\text { Single answer question } \\
\text { Coded as written }\end{array}$ \\
\hline
\end{tabular}




\begin{tabular}{|c|c|c|}
\hline & $\begin{array}{l}\text { +1)Important } \\
\text { 0)Neutral } \\
\text {-1)Unimportant } \\
\text {-2)Completely } \\
\text { unimportant } \\
\text { 6)I choose not to answer this } \\
\text { question. }\end{array}$ & $\# 6=99$ \\
\hline 125. Thankful clients/patients is: & $\begin{array}{l}\text { +2)Completely } \\
\text { important } \\
+1 \text { )Important } \\
\text { 0)Neutral } \\
\text {-1)Unimportant } \\
\text {-2)Completely } \\
\text { unimportant } \\
\text { 6)I choose not to answer this } \\
\text { question. }\end{array}$ & $\begin{array}{l}\text { Single answer question } \\
\text { Coded as written } \\
\# 6=99\end{array}$ \\
\hline $\begin{array}{l}\text { 126. Achieving a good reputation } \\
\text { as a registered dietitian is: }\end{array}$ & $\begin{array}{l}\text { +2)Completely } \\
\text { important } \\
+1 \text { )Important } \\
\text { 0)Neutral } \\
\text {-1)Unimportant } \\
\text {-2)Completely } \\
\text { unimportant } \\
\text { 6)I choose not to answer this } \\
\text { question. }\end{array}$ & $\begin{array}{l}\text { Single answer question } \\
\text { Coded as written } \\
\# 6=99\end{array}$ \\
\hline $\begin{array}{l}\text { 127. Less food poisoning among } \\
\text { my local community is: }\end{array}$ & $\begin{array}{l}\text { +2)Completely } \\
\text { important } \\
+1 \text { )Important } \\
\text { 0)Neutral } \\
\text {-1)Unimportant } \\
\text {-2)Completely } \\
\text { unimportant } \\
\text { 6)I choose not to answer this } \\
\text { question. }\end{array}$ & $\begin{array}{l}\text { Single answer question } \\
\text { Coded as written } \\
\# 6=99\end{array}$ \\
\hline $\begin{array}{l}\text { 128. Knowing that my } \\
\text { clients/patients are not } \\
\text { substituting canned vegetables } \\
\text { for fresh vegetables: }\end{array}$ & $\begin{array}{l}\text { +2)Completely } \\
\text { important } \\
+1 \text { )Important } \\
\text { 0)Neutral } \\
\text {-1)Unimportant } \\
\text {-2)Completely } \\
\text { unimportant } \\
\text { 6)I choose not to answer this } \\
\text { question. }\end{array}$ & $\begin{array}{l}\text { Single answer question } \\
\text { Coded as written } \\
\# 6=99\end{array}$ \\
\hline $\begin{array}{l}\text { 129. Knowing that my } \\
\text { clients/patients are not } \\
\text { substituting frozen vegetables } \\
\text { for fresh vegetables is: }\end{array}$ & $\begin{array}{c}\text { +2)Completely } \\
\text { important } \\
+1) \text { Important } \\
\text { 0)Neutral } \\
\text {-1)Unimportant } \\
\text {-2)Completely }\end{array}$ & $\begin{array}{l}\text { Single answer question } \\
\text { Coded as written } \\
\# 6=99\end{array}$ \\
\hline
\end{tabular}




\begin{tabular}{|c|c|c|}
\hline & $\begin{array}{l}\text { unimportant } \\
\text { 6)I choose not to answer this } \\
\text { question. }\end{array}$ & \\
\hline $\begin{array}{l}\text { 130. Teaching clients/patients } \\
\text { who are listening to me is: }\end{array}$ & $\begin{array}{l}\text { +2)Completely } \\
\text { important } \\
+1 \text { )Important } \\
\text { 0)Neutral } \\
\text {-1)Unimportant } \\
\text {-2)Completely } \\
\text { unimportant } \\
\text { 6)I choose not to answer this } \\
\text { question.. }\end{array}$ & $\begin{array}{l}\text { Single answer question } \\
\text { Coded as written } \\
\# 6=99\end{array}$ \\
\hline $\begin{array}{l}\text { 131. Teaching information to my } \\
\text { clients/patients, which } I \\
\text { personally have strong beliefs for } \\
\text { is: }\end{array}$ & $\begin{array}{l}\text { +2)Completely } \\
\text { important } \\
+1 \text { )Important } \\
\text { 0)Neutral } \\
\text {-1)Unimportant } \\
\text {-2)Completely } \\
\text { unimportant } \\
\text { 6)I choose not to answer this } \\
\text { question. }\end{array}$ & $\begin{array}{l}\text { Single answer question } \\
\text { Coded as written } \\
\# 6=99\end{array}$ \\
\hline $\begin{array}{l}\text { 132. Teaching fresh vegetable } \\
\text { food safety to clients/patients that } \\
\text { are considered high-risk for } \\
\text { foodborne illness is: }\end{array}$ & $\begin{array}{l}\text { +2)Completely } \\
\text { important } \\
+1 \text { )Important } \\
\text { 0)Neutral } \\
\text {-1)Unimportant } \\
\text {-2)Completely } \\
\text { unimportant } \\
\text { 6)I choose not to answer this } \\
\text { question. }\end{array}$ & $\begin{array}{l}\text { Single answer question } \\
\text { Coded as written } \\
\# 6=99\end{array}$ \\
\hline $\begin{array}{l}\text { 133. A balance of the number of } \\
\text { fruits and vegetables among my } \\
\text { clients/patients (rather than all } \\
\text { fruit and few fresh vegetables) is: }\end{array}$ & $\begin{array}{l}\text { +2)Completely } \\
\text { important } \\
+1 \text { )Important } \\
\text { 0)Neutral } \\
\text {-1)Unimportant } \\
\text {-2)Completely } \\
\text { unimportant } \\
\text { 6)I choose not to answer this } \\
\text { question. }\end{array}$ & $\begin{array}{l}\text { Single answer question } \\
\text { Coded as written } \\
\# 6=99\end{array}$ \\
\hline $\begin{array}{l}\text { 134. Using registered dietitians } \\
\text { as one's sole source of fresh } \\
\text { vegetable food safety } \\
\text { information is: }\end{array}$ & $\begin{array}{l}\text { +2)Completely } \\
\text { important } \\
+1 \text { Important } \\
\text { 0)Neutral } \\
\text {-1)Unimportant } \\
\text {-2)Completely } \\
\text { unimportant } \\
\text { 6)I choose not to answer this } \\
\text { question. }\end{array}$ & $\begin{array}{l}\text { Single answer question } \\
\text { Coded as written } \\
\# 6=99\end{array}$ \\
\hline
\end{tabular}




\begin{tabular}{|c|c|c|}
\hline $\begin{array}{l}\text { 135. Choosing locally grown } \\
\text { vegetables because they are less } \\
\text { likely to be contaminated with } \\
\text { bacteria is: }\end{array}$ & $\begin{array}{l}\text { +2)Completely } \\
\text { important } \\
+1 \text { )Important } \\
\text { 0)Neutral } \\
\text {-1)Unimportant } \\
\text {-2)Completely } \\
\text { unimportant } \\
\text { 6)I choose not to answer this } \\
\text { question. }\end{array}$ & $\begin{array}{l}\text { Single answer question } \\
\text { Coded as written } \\
\# 6=99\end{array}$ \\
\hline $\begin{array}{l}\text { 136. Choosing locally grown } \\
\text { fresh vegetables for their taste is: }\end{array}$ & $\begin{array}{l}\text { +2)Completely } \\
\text { important } \\
+1 \text { )Important } \\
\text { 0)Neutral } \\
\text {-1)Unimportant } \\
\text {-2)Completely } \\
\text { unimportant } \\
\text { 6)I choose not to answer this } \\
\text { question. }\end{array}$ & $\begin{array}{l}\text { Single answer question } \\
\text { Coded as written } \\
\# 6=99\end{array}$ \\
\hline $\begin{array}{l}\text { 137. Choosing locally grown } \\
\text { fresh vegetables for their quality } \\
\text { is: }\end{array}$ & $\begin{array}{l}\text { +2)Completely } \\
\text { important } \\
+1 \text { Important } \\
\text { 0)Neutral } \\
\text {-1)Unimportant } \\
\text {-2)Completely } \\
\text { unimportant } \\
\text { 6)I choose not to answer this } \\
\text { question. }\end{array}$ & $\begin{array}{l}\text { Single answer question } \\
\text { Coded as written } \\
\# 6=99\end{array}$ \\
\hline $\begin{array}{l}\text { 138. Choosing locally grown } \\
\text { fresh vegetables as a way to help } \\
\text { our local economy is: }\end{array}$ & $\begin{array}{l}\text { +2)Completely } \\
\text { important } \\
+1 \text { )Important } \\
\text { 0)Neutral } \\
\text {-1)Unimportant } \\
\text {-2)Completely } \\
\text { unimportant } \\
\text { 6)I choose not to answer this } \\
\text { question. }\end{array}$ & $\begin{array}{l}\text { Single answer question } \\
\text { Coded as written } \\
\# 6=99\end{array}$ \\
\hline $\begin{array}{l}\text { 139. Choosing organic } \\
\text { vegetables for their taste is: }\end{array}$ & $\begin{array}{l}\text { +2)Completely } \\
\text { important } \\
+1 \text { Important } \\
\text { 0)Neutral } \\
\text {-1)Unimportant } \\
\text {-2)Completely } \\
\text { unimportant } \\
\text { 6)I choose not to answer this } \\
\text { question. }\end{array}$ & $\begin{array}{l}\text { Single answer question } \\
\text { Coded as written } \\
\# 6=99\end{array}$ \\
\hline $\begin{array}{l}140 . \text { Choosing organic } \\
\text { vegetables for their increased } \\
\text { nutritional qualities is }\end{array}$ & $\begin{array}{l}+2) \text { Completely } \\
\text { important }\end{array}$ & $\begin{array}{l}\text { Single answer question } \\
\text { Coded as written }\end{array}$ \\
\hline
\end{tabular}




\begin{tabular}{|c|c|c|}
\hline & $\begin{array}{l}\text { +1)Important } \\
\text { 0)Neutral } \\
\text {-1)Unimportant } \\
\text {-2)Completely } \\
\text { unimportant } \\
\text { 6)I choose not to answer this } \\
\text { question. }\end{array}$ & $\# 6=99$ \\
\hline $\begin{array}{l}\text { 141. Choosing organic } \\
\text { vegetables because they are less } \\
\text { likely to be contaminated with } \\
\text { bacteria is: }\end{array}$ & $\begin{array}{l}\text { +2)Completely } \\
\text { important } \\
+1 \text { )Important } \\
\text { 0)Neutral } \\
\text {-1)Unimportant } \\
\text {-2)Completely } \\
\text { unimportant } \\
\text { 6)I choose not to answer this } \\
\text { question. }\end{array}$ & $\begin{array}{l}\text { Single answer question } \\
\text { Coded as written } \\
\# 6=99\end{array}$ \\
\hline $\begin{array}{l}\text { 142. Choosing organic fresh } \\
\text { vegetables because they are less } \\
\text { likely to be contaminated with } \\
\text { pesticides and herbicides is: }\end{array}$ & $\begin{array}{l}\text { +2)Completely } \\
\text { important } \\
+1 \text { )Important } \\
\text { 0)Neutral } \\
\text {-1)Unimportant } \\
\text {-2)Completely } \\
\text { unimportant } \\
\text { 6)I choose not to answer this } \\
\text { question. }\end{array}$ & $\begin{array}{l}\text { Single answer question } \\
\text { Coded as written } \\
\# 6=99\end{array}$ \\
\hline \multicolumn{3}{|c|}{ Read each of the following statements. Mark the box that is the closest match to your own opinion. } \\
\hline $\begin{array}{l}\text { 143. I am worried that I may get } \\
\text { sick if I eat hot dogs right out of } \\
\text { the package. }\end{array}$ & $\begin{array}{l}\text { 5) strongly agree } \\
\text { 4) agree } \\
\text { 2) disagree } \\
\text { 1) strongly disagree } \\
\text { 6) I choose not to answer this } \\
\text { question }\end{array}$ & $\begin{array}{l}\text { Single answer question } \\
\text { Coded as written } \\
\# 6=99\end{array}$ \\
\hline $\begin{array}{l}\text { 144. Using cheese and yogurt } \\
\text { made only from pasteurized milk } \\
\text { is important to me. }\end{array}$ & $\begin{array}{l}\text { 5) strongly agree } \\
\text { 4) agree } \\
\text { 2)disagree } \\
\text { 1) strongly disagree } \\
\text { 6) I choose not to answer this } \\
\text { question }\end{array}$ & $\begin{array}{l}\text { Single answer question } \\
\text { Coded as written } \\
\# 6=99\end{array}$ \\
\hline $\begin{array}{l}\text { 145. I am not concerned that I may } \\
\text { get sick if I eat raw oysters. }\end{array}$ & $\begin{array}{l}\text { 1) strongly agree } \\
\text { 2) agree } \\
\text { 4) disagree } \\
\text { 5) strongly disagree } \\
\text { 6) I choose not to answer this } \\
\text { question }\end{array}$ & $\begin{array}{l}\text { Single answer question } \\
\text { Coded as written } \\
\# 6=99\end{array}$ \\
\hline 146. I don't worry about keeping & 1) strongly agree & Single answer question \\
\hline
\end{tabular}




\begin{tabular}{|c|c|c|}
\hline $\begin{array}{l}\text { the refrigerator at or below } 40 \\
\text { degrees F. }\end{array}$ & $\begin{array}{l}\text { 2) agree } \\
\text { 4) disagree } \\
\text { 5) strongly disagree } \\
\text { 6) I choose not to answer this } \\
\text { question }\end{array}$ & $\begin{array}{l}\text { Coded as written } \\
\# 6=99\end{array}$ \\
\hline $\begin{array}{l}\text { 147. I don't worry that I may get } \\
\text { sick if I eat alfalfa and other raw } \\
\text { sprouts. }\end{array}$ & $\begin{array}{l}\text { 1) strongly agree } \\
\text { 2) agree } \\
\text { 4) disagree } \\
\text { 5) strongly disagree } \\
\text { 6) I choose not to answer this } \\
\text { question }\end{array}$ & $\begin{array}{l}\text { Single answer question } \\
\text { Coded as written } \\
\# 6=99\end{array}$ \\
\hline $\begin{array}{l}\text { 148. I am not interested in using a } \\
\text { food thermometer. }\end{array}$ & $\begin{array}{l}\text { 1) strongly agree } \\
\text { 2) agree } \\
\text { 4) disagree } \\
\text { 5) strongly disagree } \\
\text { 6) I choose not to answer this } \\
\text { question }\end{array}$ & $\begin{array}{l}\text { Single answer question } \\
\text { Coded as written } \\
\# 6=99\end{array}$ \\
\hline $\begin{array}{l}\text { 149. After cutting raw meat or } \\
\text { chicken, I like to wash the cutting } \\
\text { board, knife and counter top with } \\
\text { hot soapy water before continuing } \\
\text { cooking. }\end{array}$ & $\begin{array}{l}\text { 5) strongly agree } \\
\text { 4) agree } \\
\text { 2)disagree } \\
\text { 1) strongly disagree } \\
\text { 6) I choose not to answer this } \\
\text { question }\end{array}$ & $\begin{array}{l}\text { Single answer question } \\
\text { Coded as written } \\
\# 6=99\end{array}$ \\
\hline $\begin{array}{l}\text { 150. Drinking pasteurized apple } \\
\text { juice or cider is important to me } \\
\text { for safety. }\end{array}$ & $\begin{array}{l}\text { 5) strongly agree } \\
\text { 4) agree } \\
\text { 2)disagree } \\
\text { 1) strongly disagree } \\
\text { 6) I choose not to answer this } \\
\text { question }\end{array}$ & $\begin{array}{l}\text { Single answer question } \\
\text { Coded as written } \\
\# 6=99\end{array}$ \\
\hline $\begin{array}{l}\text { 151. Cooking and eating eggs that } \\
\text { have firm yolks and whites is } \\
\text { important to me for safety. }\end{array}$ & $\begin{array}{l}\text { 5) strongly agree } \\
\text { 4) agree } \\
\text { 2)disagree } \\
\text { 1) strongly disagree } \\
\text { 6) I choose not to answer this } \\
\text { question }\end{array}$ & $\begin{array}{l}\text { Single answer question } \\
\text { Coded as written } \\
\# 6=99\end{array}$ \\
\hline $\begin{array}{l}\text { 152. I am not concerned if I thaw } \\
\text { perishable food on the kitchen } \\
\text { counter. }\end{array}$ & $\begin{array}{l}\text { 1) strongly agree } \\
\text { 2) agree } \\
\text { 4) disagree } \\
\text { 5) strongly disagree } \\
\text { 6) I choose not to answer this } \\
\text { question }\end{array}$ & $\begin{array}{l}\text { Single answer question } \\
\text { Coded as written } \\
\# 6=99\end{array}$ \\
\hline
\end{tabular}

Version 1, November 17, 2008, Medeiros 


\section{APPENDIX D: STEPS FOR STATISTICS}

\section{Step 1: Spearman correlation}

- Spearman correlation analysis was chosen since the dependent variables were categorical.

- Spearman correlation analysis was conducted against each of the belief variables (PBC, Atd, SN, 7 separate attitude belief variables) and the two dependent variables (multinomial and binary).

Step 2: Creation of the belief variables

- $\quad$ PBC and SN items were both scored in a unipolar fashion, on a scale of 1 to 5

- The PBC belief variable was created by averaging the scores of the two "control belief" items.

- The SN belief variable was created by averaging the scores of the products of the "normative belief" and "motivation to comply" items.

- Atd items were scored in a bipolar fashion, on a scale of -2 to 2

- The Atd belief variable was created by averaging the scores of the products of the "behavioral belief" and "outcome evaluation" items (See example below).

\section{Example:}

Behavioral Belief Question (bolded item is the answer of the participant)

\begin{tabular}{|l|l|}
\hline 110. Less foodborne illness & 2)Very likely \\
among my clients/patients. & 1)Likely \\
& 0)Neutral \\
& -1)Unlikely \\
& -2)Very unlikely \\
& 6)I choose not to answer \\
& this question. \\
\hline
\end{tabular}

Outcome Evaluation (bolded item is the answer of the participant)

\begin{tabular}{|l|l|}
\hline 123. Less food poisoning among & \\
my clients is: & 2)Completely important \\
& 1)Important \\
& 0)Neutral \\
\hline
\end{tabular}




\begin{tabular}{|l|l|}
\hline & \multicolumn{1}{|c|}{$\begin{array}{c}\text {-1)Unimportant } \\
\text {-2)Completely } \\
\text { unimportant }\end{array}$} \\
& $\begin{array}{l}\text { 6)I choose not to answer this } \\
\text { question. }\end{array}$ \\
\hline
\end{tabular}

In order to determine the attitude regarding teaching fresh vegetable food safety and less food poisoning, we multiplied the score of the "behavioral belief" item by the score of the "outcome evaluation" item:

$2 \times(-1)=-2$

Because the answer was negative, this denoted a negative attitude toward teaching fresh vegetable food safety and less food poisoning.

Step 3: Multinomial logistic regression

- The multinomial dependent variable was created by coding "Currently teach" as 2 , "Intend to teach" as 1 , and "Neither" as 0 .

- Analyses' were run with belief variables against the multinomial dependent variable.

Step 4: Binary logistic regression

- The binary dependent variable was created by coding "Currently teach" as 1 , and both "Intend to teach", and "Neither" as 0 .

- Analyses' were run separately with belief variables against the binary dependent variable. 